\title{
Elobmrata Sarias
}

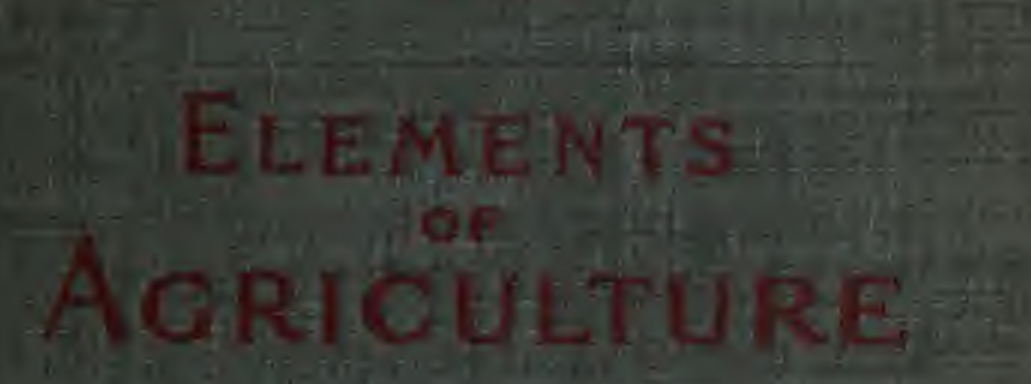

\section{I.B.MUERVE}

\section{UC-NRLF}

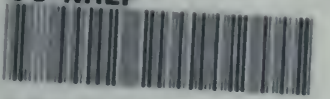
\$8 301 231

\section{4} i 


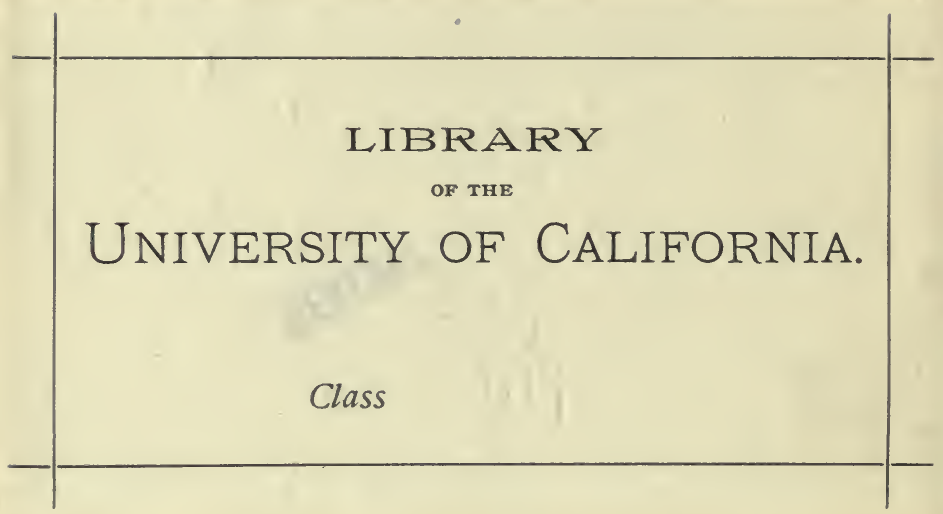


Digitized by the Internet Archive in 2008 with funding from Microsoft Corporation 




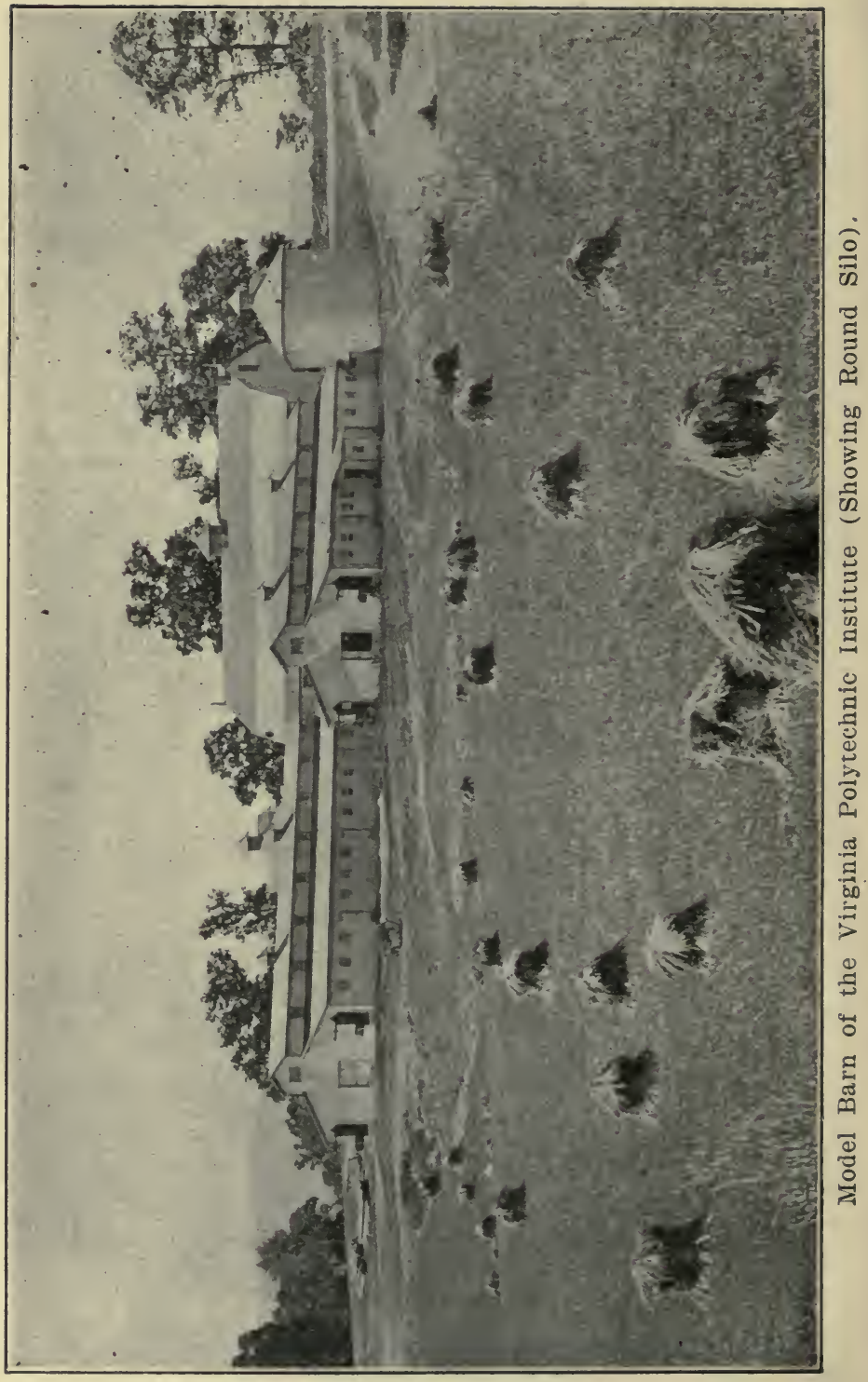




\title{
Elements of Agriculture
}

\author{
FOR USE IN SCHOOLS
}

\author{
BY \\ JAMES BOLTON MCBRYDE, C. E. \\ VIRGINIA POLYTECHNIC INSTITUTE
}

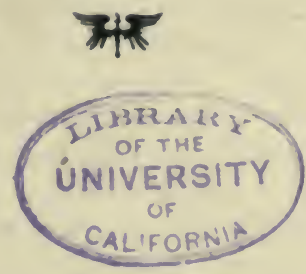

RICHMOND, VA.

a. F. JOHNSON PUBLISHING CO. 1901 


\section{GENERAL}

\section{Copyright, 1901, by \\ JaMes Bolton MCBRydE}

All rights reserved.

9-07-H. I. 


\section{PREFACE}

The pressing need of -some agricultural instruction in our public schools is generally admitted by all who have given due thought to the subject. Especially is this true in the Southern States, where the great majority of the population is engager in agricultural pursuits, and where comparatively few students from the rural districts fiud their way to college. According to the census of 1900 , the total population of the Southern States is about $23,000,000$. Of this number 11 :e rural population makes up fully 75 per cent or more; in other words, about $17,000,000$. The total number of persons enrolled during the session of 1898-99, as students of agriculture in the land-grant colleges of the South was 1,777 , or about .0001 per cent of the agricultural population. The number of persons receiving agricultural instruction outside of these colloges is so small as not materially to affect the result, and it is safe to say that of the agricultural population of the South not more than one person in 10,000 receives any schooling in agriculture. We have, then, the amazing speetacle of an agricultural community that is spending annually for its schools and colleges about $\$ 35,000,000$, and yet giving instruction in agriculture to only one person in every 10,000 of the agricultural population.

That there are still great difliculties in the way of the work of agricultural education is freely admitted. The want of thoroughly trained teachers, the need of more and better apparatus and text-books, and the want of appreciation on the part of the general public, are great barriers in the way of progress. But these barriers must and will in time be removed, teachers will be better trained, more and better apparatus will be provided, better text-books will be written, and when all this comes to pass the public will soon learn to appreciate this line of educational effort. 
The object in preparing this little book has been to present in simple language some of the more important principles of agriculture, with the hope that as herein set forth they may serve to stimulate in the pupil a desire for further information on the subject. Details have been as far as possible avoided, for to attempt to load the pupil's mind with a mass of details would be to defeat at the start the primary object of the book. It must be borne in mind that within the limits of an ordinary volume it is impossible to present more than a very brief outline of the first principles of agriculture. Many topics must be omitted entirely and others touched upon very briefly.. It is hoped, however, that these first prineiples may provide the student with a ground-work upon which to build a more perfect knowledge of agriculture.

Teachers should, whenever possible, supplement and illustrate the text by examples drawn from their own observations and experience, and should encourage pupils to observe and investigate for themselves.

For revising my manuscript and for many valuable suggestions, my thanks are due Dr. J. M. McBryde, of the Virginia Polytechnic Institute; Prof. T. C. Karns, of Tennessee; Mr. J. F. Jackson, of the Southern Planter; Prof. D. O. Nourse, of the Virginia Polytechnic Institute; Mr. David Cloyd, of Dublin, Va.; Prof. C. E. Vawter, of the Miller Manual School; Dr. J. M. McBryde, Jr, of Hollins Institute, and Dr. F. D. Wilson, of the Virginia Polytechnic Institute. For the illustrations I am indebted to Dr. Chas. N. McBryde, of the Virginia Polytechnic Institute.

\section{J. B. McB.}

Virginia Polytechnic Institute, Blacksburg, Va. 


\section{CON'TEN'TS}

CRAPTER

PART I-Cumate

I. Sunlight, - $\quad$ - $\quad$ - $\quad$ - 0

II. Sunlight (Continued), - - - 14

III. Rain, - - . - . 18

1V. The Atmosphere, - - - - $\quad 23$

V. The Atmosphere (Continued), - $\quad$ - 28

\section{PART II-PLANTS}

VI. l'lants and Their Seed, - - $\quad 33$

VII. Parts of a Plant, - - - $\quad 38$

VIII. Composition of Plants, - . - 45

Ix. Composition of llants (Continued), - $\quad 50$

X. The Food the Plant Takes from the Soil, 55

xi. The Foor the Plant Takes from the Air, 60

XII. How llants Grow, - $\quad 63$

\section{P'AR'T III-SOILS}

XIII. How Soils are Made, - $\quad$ - $\quad 67$

Xly. Classification of Soils, - - $\quad$ - 72

XV. Composition of Soils, - - $\quad 78$

XVI. Composition of Soils (Continued), - $\quad 83$

rvil. Water in Soils, - $\quad$ - $\quad$ - 88

SVIIl. Nitrogen in the Soil, - $\quad$ - $\quad 94$

XIX. How Soils Iose Water, - . - 100

XX. How Soils Lose Nitrogen, - . 106

XXI. How Soils Lose Mineral Matter, - 110

XxII. Cultiration of Soils, - _ $\quad 117$

XxIII. Cultivation of Scils (Continued), - 122

PART IV-MANURES

XXIV. Classifieation of Manures, - 128

XXV. Commereial Fertilizers, - - - 133

XXVI. Commercial Fertilizers (Continued), - 138

XXVII. Use of Manures, - . $\quad$ - 145 
CHAPTER

XXVIII. Seed Testing,

XXIX. Classification of Crops: Cereal and Fod-

XXX. Fodder Crops and Pastures,

XXXI. Root and Tuber Crops: Miscellaneous Crops,

XXXII. Rotation of Crops,

\section{PART VI-Animal Production}

XXXIII. Composition of Animals, -

XXXIV. Food, Work, and Growth of Animals, - 186

XXXV. Care of Animals, - $\quad$ - $\quad$ - $\quad$ - 190

XXXVI. Feeding of Animals, - $\quad$ - $\quad$ - 195

XXXVII. Stock Food, - $\quad$ - $\quad$ - $\quad$ : 198

XXंXVIII. Digestibility of Stock Foods, - $\quad$ - 204

XXXIX. Calculating Rations for Animals, - 208

XL. Selecting Stock Foods, - _ - - 214

PART VII-Miscellaneous Topics

XLI. Birds,

XLII. Insectivorous Birds,

XLIII. Seed-Eating Birds,

XLIV. Birds of Prey,

XLV. Forestry, -

XLVI. Roads,

APPENDIX
218

22.2

228

232

238

243

$\begin{array}{llllll}\text { Tables, } & - & - & - & \ldots & 251 \\ \text { Index, - } & - & - & - & - & 261\end{array}$ 


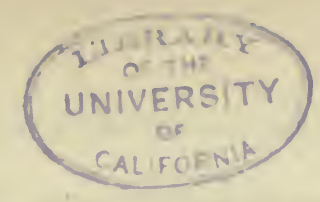

\section{Elements of Agriculture}

\section{PART I.-CLIMATE}

\section{CHAPTER I.-SUNLIGHT}

1. Sunlight the Source of all Life.-Sunlight, water and air, all three so important to our health and happiness, are equally necessary to the health and growth of plants. Children raised in the foul, dark slums of a city are apt to be sickly both in mind and body. The strongest alone survive, and they too often grow up as full of evil as their surroundings. Poor children! Their lives are spent between the dull brick walls of the city, with seldom a glimpse of the country with its glorious sunlight, its birds and its flowers. How can they grow up to be perfect men and women? No more can the little plant struggling along in some dark corner grow up to its full benuty and power.

The light and heat which come to us from the sun in the form of sunshine are, as every child should know, the sources of all life on this earth; hence to sunshine agrienlture owes its very existence. But little is yet known of this quickener of life. It is known that sunshine produces both heat and light, and that the two may be separated, but much remains to be discovered in regard to it; and men now unknown may make their names immortal by telling the world more about it. 
2. Heat.-A stone thrown into a quiet pool of water produces waves, which move rapidly from the place where the stone struck to the shore, where, striking against the grains of sand and soil particles, they shake them about. When sunshine comes to the earth from the sun, it moves in waves just as perfect as those produced in the water. But the waves of sunshine travel very much faster than the waves of water, and are so very small that they cannot be seen. Now, these waves of sunshine coming from the sun strike against the surface of the earth and shake up its very small particles, or molecules, as they should be called, much as the waves in the pool of water shake up the particles of soil on the shore. From the motion produced among its surface molecules the earth becomes warmed. If a crowd of children are all running about very fast and bumping into one another they soon become quite warm from the violent exercise. So with the small particles or molecules against which the sun's heat strikes; they become much excited, move about very rapidly, bump into one another, and are thus warmed.

3. Steam.-When a kettle of water is put over a fire to boil, the little heat waves from the fire, which are like those from the sun, first warm up the kettle. When the kettle becomes warm it transfers some of its heat to the water, and so motion begins among the molecules of water. This motion is slow at first, but as the heat waves from the fire continue to strike against the kettle, more and more heat passes through to the water, and 
the motion of its molecules becomes faster. Soon the water begins to bubble and boil from the rapid motion of its molecules. Some of the surface molecules from their rapid motion are thrown off from the boiling water and float about in the air in the form of a gas, which is called sTeas.

4. Condensation.-If, in the stcam from a boiling kettle, some cold object is held for a few moments drops of water collect on it. The hented molecules which make up the steam strike against the cold object and are cooled off, become quiet, and collect in drops of water. The steam is said to coNDr.sse. When steam rises from boiling water into the air above, it cools off and gathers into fine drops of moisture, which make up the white steam to be seen rising from hot water. Notice how dense and white the steam is on a cold day.

5. Evaporation.-When heat waves from the sun strike against bodies of water, such as oceans, lakes and rivers, they eause rapid motion among the surface molecules of water; this motion is so strong at times that many of the water molecules are thrown off into the air above as they were from the kettle of boiling water. This change is called evaroration. But evaporation is not dependent on sunshine, though it takes place more rapidly under its influence. Air has the power of taking up water like a sponge, and like the sponge can hold only a certain amount. When air has taken up all the water it can hold, it is snid to be saturatrid. Then evaporation ceases, but so long as the air is not saturated evaporation may go on. A bucket of water placed in a room protected from sunshine gradually erapo- 
rates, and so long as fresh air is admitted to the room so long will evaporation take place. Wind causes rapid evaporation; sweeping across bodies of water, the air takes up water as it goes; it is somewhat like passing a dry sponge over a wet slate. Of course, the water warmed by the sun does not actually boil. Water evaporates when it is warmed, and the more it is warmed the more rapidly it evaporates.

6. Mist, Clouds.-Most of us have noticed on a cool, frosty morning, when the sunshine strikes a pond or river, how it steams like a great boiling kettle of water. This is all the work of the little heat waves from the sun. They evaporate the surface water, which, rising into the cool air, is condensed into tiny drops of water, which form MisT. Mist, then, is made up of very small drops of water. Mist, or fog, as it is sometimes called, rises high above the earth and gathers into what we call CLOUDS.

7. Rain.-Clouds which we see floating about in the air are still warm from the sunshine which helped to form them. When they come in contact with a cold current of air, or a cold mountain top, they lose this heat and condense to drops of water, which being heavier than air fall as rain. The cold air or mountain top acts just as any cold body would if held in a cloud of steam.

8. Hail, Snow.-Sometimes raindrops are caught in very cold currents of air. In these air currents they are held till they become balls of ice, in which form they fall as HAIL. When the air becomes sufficiently cold, 
the moisture in clouds is frozen into ice crystals, which fall as sNow.

\section{Questions}

1. To what does agriculture owe its existence? 2. What does sunshine bring to the eurth? Can the two be separated? 3. How does sunshine travel to us from the sun? 4. If you tilrow a stone into a quiet pool of water, what sort of motion is started on the surface of the water? 5. Why can't we see tvaves of sunshine? 6. What happens when waves in a pond of water strike the shore? 7 . What happens when waves of sunshine strike the earth's surface? 8 . When sunshine strikes hodies of water what happens? 9. What is steam? 10. How are raindrops formed? 11. What is snow? 


\section{CHAPTER III.-SUNUIIGHT}

(CoNTinued)

9. Solids, Liquids, and Gases.-The changes which water goes through when it evaporates to form clouds; and the freezing of clouds to hail or snow, show that water may exist in three different forms: first as a LIQUID, second as a GAS, and third as a solid. Everything we know is either a liquid, solid, or gas. Water may be easily changed from one form to another, but many substances are very difficult to change. Iron, a solid, when heated very hot, melts to a liquid, and it may even be heated so hot that it becomes a gas. Air, under pressure, has been liquefied by intense cold, and other wonderful changes have been made. As a rule, heat eauses substances to expand and melt, and if they are heated sufficiently high they expand still more and become.gases. On the other hand, cold causes most substances to contract and change from gases to liquids, and from liquids to solids. This expanding and contracting of bodies is made use of in the thermometer, which is a tube partly filled with mercury or alcohol. All of the air is carefully taken out of the tube, the mercury is then put in, and the tube sealed up. When the mercury is heated it expands and rises in the tube; when it cools off it contracts and falls. By this rising and falling in the tube we measure the intensity of heat - or cold. 
10. Winds.-The heat waves from the sun perform an important duty in 'making winds. When the surface of the earth is warmed by the heat waves from the sun, it in turn warms up the air which is pressing against it. Warm air rises, and cold air, which is heavier, moves in to take its place. Thus the air is constantly moving about, and the motion is called wriv. The motion of the air helps to keep the earth from becoming too hot. Heated air rises and takes with it a quantity of heat from the earth; colder air eomes in its place, and this in its turn is warmed up and carries off more heat. So this changing may go on until the earth is cooled off. Notice the air near a stone or brick wall some hot day and see the waves of hot air rising. When a fire is built on $a$. hearth it first heats the air, which, rising up the chimney, causes a draught. Winds are distributers of rain; moving over the country they carry with them clouds of moisture, which, when condensed, fall as rain. The winds from the oceans bring in to the land great quantities of rain clouds.

11. Radiation.-During the summer, when the sun pours down great quantitics of heat day after day, the earth becomes thoroughly warmed up. The land is warmed by the sunshine, and bodies of water are warmed even more thoroughly than the soil. Thus the earth is storing up heat in land and water for use at night and in the cold winter. At night, when the sun has set and the supply of heat waves is temporarily shut off, the air would become very cold but for the heat thic earth has stored during the day. The air pressing against the earth is warmed by the stored heat, and thus 
prevented from becoming intensely cold. When the earth warms up the air it is said to RADIATE its heat. Radiation means that a warm body is throwing off heat: The sun radiates heat; a hot stove or fire also radiates heat. The earth always gives up its heat when colder air. presses against its surface. Thus radiation may take place at any time, but it is usually greater at night, because the air is then colder.

12. Light Waves-The light waves which come to tis from the sun along with the heat waves also have their part to play in aiding the growth of plants and animals. Just what effect they have we do not certainly know, but we do know that light is absolutely necessary to the growth of most plants. In far northern countries, such as Norway and Siberia, farm crops make a more rapid growth than they do farther south. This rapid growth must be due to the abundance of light, for the days are never very warm, and often the ground is frozen a few feet below the surface. But during the season when plants grow the sun shines almost continuously, the nights being only about an hour long, and the plants are thus abundantly supplied with sunshine.

\section{Questions}

1. What are the three forms in which all substances exist? 2. In which of these forms does water naturally exist? 3 . When water is heated, what form does it take? 4 . When water is frozen, what form does it take? 5. How does heat affect iron? 6. How may air be changed into a liquid? 7 . What effect has heat on most substances? 8. What effect has cold on liquids and gases? 9. What is a thermometer? 10. How is a thermometer made? 11. What causes winds? 12. Tell how the 
heat waves from the sun set in motion air currents. 13. How do winds cool the surface of the earth? 14. How are rains distributed over the earth? 15. How is the earth kept warm at night? 16. What is radiation? 17. Why do farm erops grow more rapidly in northern than in southern couniries?

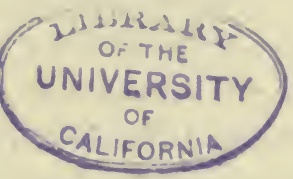




\section{CHAPTER III.-RAIN}

13. Work of Rain.-We learned in the last chapter how rain clouds are formed; so now it is in order to consider the work done by the falling of these clouds as rain. Besides supplying water for our own use and for the needs of our animals and crops, what does the rain do on a farm?

14. Erosion, Land Washing.-Did you ever notice how muddy all the creeks and rivers are after a heavy rain, and did you ever stop to think where all this mud comes from and where it is going? The gullies in the hillsides should tell you where the mud comes from; the sand bars and islands in the rivers and creeks tell you where part of it has gone. The next time it rains notice how the raindrops gather in low places into little streams of water, which carry away particles of soil and trash. As the rain becomes harder, more and more water gathers in these little streams, and more particles are moved along by them. These small particles of soil and pieces of gravel rushed along by the water grind each other into smaller fragments, loosen other particles from the soil, and so a gully grows in the hillside. This making of gullies is called ERosion.

15. Sediment.-Now, where does the water carry the soil and trash which it takes from the hillsides? Follow one of these little streams of water and you will see that where it reaches level ground it moves more slowly 
and drops most of the soil and trash which it is carrying. But it is still muddy from the fine particles which do not settle. 'These it takes to the nearest creek, which in turn takes them on to some river, which takes them to a sea or lake, and here they finally settle to a resting place in its bed. The particles of soil and trash carried by the water are called sEDimext, and when this settles out from water it is said to be deposited. Thus muddy water is said to deposit sediment.

Just try to think of the vast number of little streams of water at work each day carrying off soil from exposed hillsides. Much of this soil is deposited in the bottom lands of creeks and rivers, which are thus often made rich at the expense of the hills. But most of the small particles of soil which easily float find their way through the creeks and rivers to a sea or lake, and here they are deposited as bars of mud and sand. As the river is constantly bringing down more mud and sand, these bars grow and finally rise from the water to form new land.

16. Leaching.-Rain water carries with it from the land other things besides mud and sand. Nearly every one knows that sea water is full of salt, but few stop to think where this salt comes from. It comes from the soil. 'Salt cannot be seen or tasted in ordinary soil, but it is there, along with many other substances that are also called. salts, because they are like common salt. Besides salts there are many other substances in soils, some of which dissolve in water and some do not. Common salt dissolves very easily in water, as do most of the other salts. When a rain falls, part of the water runs off on the surface of the soil, carrying with it mud 
and trash; but much of the rain soaks down into the soil and comes out again in springs and wells. The rain water in passing through the soil dissolves many substances which it takes with it when it comes from the soil. Mineral springs result when the water has dissolved much of the salts or other mineral matter in the soil. A water that has dissolved in it a large quantity of certain minerals is a HARD WATER. A SOFT WATER is one almost free from any dissolved matter. When water dissolves substances and carries them from the soil it is said to LEACH the soil. The salts and other substances which water dissolves in its passage through the soil are carried by the water until it reaches some sea or lake. Here the salts remain; for when water evaporates it carries nothing with it, the salts and other impurities being left behind. Rain water, you know, is very pure and soft. So rivers are constantly pouring salts of various kinds into the sea, and as none comes out again the sea is becoming more salty every day. This change, however, is very slow; for seas and oceans, you must remember, are very large bodies of water, and it takes a vast quantity of salt to affect them.

17. Rain as a Robber.-Judging by the way it behaves to the soil, rain water must be considered a great robber, and when farmers are careless and give it a good chance, it will undoubtedly rob the soil of much that is valuable. If allowed it will also cut great gullies in exposed fields, wash away bridges and roads, and even take away crops from the fields. But where the rain does all this mischief it is usually the fault of the 
farmer, who has not properly protected his fields, crops, and roads.

18. Evaporation as a Temperature Regulator.-Another great work done by rain is to help to keep the earth from becoming too warm. The heat waves from the sun evaporate from the earth's surface great quantities of water to form clouds." The moisture which forms these clouds has been warmed by the heat waves, and, when it rises, earries with it much heat from the earth. Rising above the earth, the clouds come in contact with the colder upper air; here their heat is given up, or radiated, and they fall back as rain. The heat which they radiate passes through the thin upper air and is lost in outer space.

\section{E.TPERIMENTS}

1. Take a glnss tumbler neurly full of water and in it stir up some ordinary soil. As soon as you stop stirring notice hou the soil particles begin to setlle, and obscrie which particles reach the boltom first. Notice also that some fine particles continue to float in the ecuter for hours or even days. These are clny particles and only seltle after a long time from still water. Add a little alum solution to this cloudy arater and see irhat acill happen.

2. Eivaporate clear spring water in a clean dish, and notice the deposit left in the dish. This deposit is made up of the salts which the spring acater confains and which it has dissolved from the soil. Rain water if etaporated in a cleun dish leaves almost no deposit.

\section{Questions}

1. How are rain clouds formed? 2. With what does the rain supply us? 3. How do rains affect exposed lards? 4. How is a gully formed? 5. Where does the soil go which is washed fiom hillsides by the rains? 6 . Why is the soil of creek and 
river bottoms usually richer than the soil of hillsides? 7 . When you stir up soil in water, which particles settle first after you stop stirring? 8. Why does not the water become perfectly clear at once? 9. Where does the sea get its salt? 10. How are salts corried from the land to the sea? 11. Does rain water contain any salt? 12. What is a hard water? 13. What is a soft water?

\section{PROBLEM}

An acre of soil one foot deep contains 43,560 cubic feet. The Mississippi River carries annually to the ocean about 3,702,758,400 cubic feet of solid material. How many acres of soil one foot deep would this amount of material form? 


\section{CHAPTER IV.-The ATMOSPHeRE}

19. Extent of the Atmosphere.-The earth is completely surrounded by a mixture of several gases, which is called the ATMOSPHERE, or AIR. The quantity of air becomes less and less as the distance from the earth's surface increases, until finally there is no more air, and what is called outer space begins. No one knows just how far the atmosphere extends above the earth, but it is rariously estimated at from 200 to 500 miles. Persons climbing high mountains all notice how the quantity of air diminishes as they ascend, and how the cold increases. In the thin air of high mountain tops breathing becomes difficult, and finally, owing to a lack of air and to the intense cold, a point is reached beyond which man cannot climb. It is probable that more than 90 per cent of the atmosphere is included in the first fifteen miles above the earth.

While the thin upper air will not furnish breath for man or beast, it serves the useful purpose of protecting the earth from the vast number of meteors-shooting stars as they are called-which are constantly falling into it. The number of metenrs striking the upper air in twenty-four hours has been estimated at two million. Meteors travel with enormous speed, and when they strike the upper air the friction produced is so great that it causes enough heat to burn them up. Most meteors are small bodies, and are burned up 80 far 
above the earth that the little light they give off is not visible. Few meteors ever reach the earth.

20. Composition of the Air.-Chemists tell us that air is a mixture, consisting principally of two gases, nitrogen and oxygen, but containing in addition to these two main elements small quantities of several other gases, and even some liquids and solids. A gas called carbonic acid, or, more properly, carbon dioxide, another gas, ammonia, and water vapor are three important gases found in small quantities in the air. Water in the rain clouds and mist make up the liquid portion of the air, and dust particles and bacteria make up the solid portions. Now, what are these various substances-nitrogen, oxygen, ammonia, etc.? They are what chemists call elements and compounds.

21. Elements.-Nitrogen and oxygen are elements. They are called ELEMen's because they cannot be divided into anything else. Iron is an element; it may be divided into the finest possible pieces, but it is still iron. There is no known way of dividing iron into anything but iron, and this is true of nitrogen and oxygen. All substances that cannot be divided into anything else are called elements. There are something over 70 elements known, but we shall be concerned in this book with not more than 16 or $1 \%$ of them.

22. Compounds.-Two or more elements may unite with each other to form substances entirely different in appearance or behavior from either of the two elements themselves. Substances made up of two or more elements are called compounds. Water is a compound, for it can be divided into two gases, oxygen and hydro- 
gen, neither of which resembles water. All compounds can be divided into two or more elements.

23. Mixtures.-Two or more elements, or compounds, may be mixed and still retain all their individual properties. When this takes place the result is a Mixture. Salt is mixed with flour to make bread, and in the mixture we cannot see any salt, but we can taste it and know from its taste that the salt is unchanged.

Now, air is a mixture of several elements and compounds. Let us see what these various substances are that go to make up air.

24. 0xygen,-This element is a gas, and makes up nearly 23 per cent by weight of the air. It is the most abundant substance on earth, making up eight-ninths of the weight of water and about 50 per cent of the weight of sand. About one-third of the weight of soil and rocks is made up of oxygen, and all plants and animals contain large quantities of the gas. Oxygen is a very active gas, always ready to combine with other zubstanees, which, when the union takes place, are said to become oxidized. When substances combine with nxygen the action produces heat. Thus the carbon in coal when it burns unites with oxygen to form a gas ealled carbon dioxide, and gires off much heat. Combined with another gas called hydrogen, oxygen forms a liquid which we know as water. Combined with iron, it forms a solid called iron ore. In plants and animals it occurs in combination as water, and also combined with some other substances to form solids. We breathe oxygen in the air, we drink oxygen in water, and we eat 
oxygen in our food. We could not live for a moment without it.

Oxygen alone is too active to support properly the growth of plants and animals. In the air it is mixed with a slow, inactive sort of gas called nitrogen.

25. Nitrogen.-In its habits this element is very much the reverse of oxygen. It makes up nearly four- fifths of the volume of the air, or $7 \%$ per cent by weight, but does not readily combine with other substances. It is, however, very useful in agriculture, as no plant or animal can grow without a supply of nitrogen. But a few plants have the power of obtaining nitrogen from the air, and animals obtain their nitrogen only from plants. Small quantities of oxygen and nitrogen are found in the air, combined with two other elements called hydrogen and carbon.

26. Hydrogen.-This element is a gas, and is the lightest of all known substances. All of the hydrogen found in the air is combined with other elements. Combined with oxygen it forms WATER; combined with nitrogen it forms AMMONIA.

27. Carbon.-This element is a solid substance, and is well known in the shape of mineral coal, which is nearly all carbon. The diamond is also very nearly pure carbon, and so is the lead of an ordinary lead pencil. Carbon when heated in excess of air unites very readily with oxygen, forming the compound, CARBON DIOXIDE. Thus when coal is burned most of it disappears into the atmosphere as a gas, carbon dioxide, leaving behind only a few ashes. A large part of all plant and animal bodies is made up of carbon. 


\section{Questions}

1. About how far above the earth is the atmosphere believed to extend? 2. Where is the air densest? 3. How does the thin upper air protect the earth? 4. What is an element? 5. What is a compound? 6. What is a mixture? 7 . Is air an element, eompound or mixture? 8. Name four gases foumd in the atmosphere. 8. Deseribe oxygen. 10. Deseribe nitrogen. 11. Describe hydrogen. 12. Name three well-known forms of carbon.

\section{PROBIFI}

Resting on each acre of land are ahout 46,200 tons of air. If this amount of air contains 23 per cent hy weight of oxygen, fincl the weight of oxygen gas resting on each acre. 


\section{CHAPTER V.-The ATMosphere}

\section{(CONTINUED)}

28. Carbon Dioxide.-Though this gas makes up a relatively small proportion of the atmosphere, it is very important, as it supplies a large part of the food of all growing plants. The air about cities usually contains more of this gas than the air of the country. The many fires which are constantly kept going in cities give off great quantities of this gas. Ordinary air contains about .035 per cent by volume, or about 0.06 per cent by weight of carbon dioxide. This seems a very small amount, but when multiplied by the vast oceans of air it becomes a large sum. It is estimated that the air covering every acre of ground contains about 28 tons of carbon dioxide, which give $101 / 2$ tons of pure carbon. The supply of earbon dioxide in the air remains always about. the same. The amount taken up by plants during their season of growth is replaced by the gas from fires, the breath of man and beast, and other sources.

29. Ammonia.-This compound, often calied hartshorn, is made up of nitrogen and hydrogen. It has a very powerful odor, but the air contains so little of it that it is not perceptible. This gas is very easily dissolved in water, and rain washes it from the air and. carries it to the soil, where it may become plant food. 
Though the amount in the air is very small, it is of some importance to plants.

30. Moisture.-Water is found in the air as a gas known as WATER VAPOR. 'I'he amount of water vapor in the air is very variable, but warm air contains more than cold air. In cold air the water vapor condenses to form clouds or mist, in which form it is no longer a gas, but a liquid. Notice how drops of water collect on the outside of a glass of ice-cold water; the warm air which contains water vapor comes in contact with the cold suriace of the glass, is cooled down, and the water vapor condenses to form drops of water. This is a good example of how dew is formed. At night when no heat comes from the sun the air becomes quite cool-cooler than the earth, which is warmed by the heat it has stored up during the day. Now, when the air becomes cool cnough, the water vapor it contains condenses to form drops of water, which are gently deposited on the surface of the carth and form DFw. Dew is rain, formed near the earth's surface. When the air becomes suffciently cold, the dew freezes and forms Frost.

Moisture in the air enrves a useful purpose in helping to keep the earth warm. 'The heat waves which come to us from the sun move with wonderful rapidity, about 186,000 miles in a second of time, and pass through the atmosphere as easily as water through a sieve. Striking the earth's surface, these heat waves warm it up; in other words, they start up other heat waves among the surface molecules of the earth. The hent waves thus started in the earth's surface move muci more slowly than the heat waves from the sun, and they in time 
start up other slow-moving heat waves in the air pressing against the earth's surface. The heat waves started in the air tend to rise, but the moist, dense air near the earth's surfące checks their upward progress and holds them till the air becomes thoroughly warmed by their motion. Rising slowly through the dense air near the earth, the heat waves finally reach the thin upper air through which they pass very casily, and are soon lost in outer space. High mountain tops are surrounded by thin air, through which the heat waves from the earth pass so rapidly that it never becomes thoroughly warm, consequently they are always cold. The dense layer of air near the earth's surface acts like a heavy blanket or-covering; the thin air of mountain tops is a very poor covering.

Dew and frost seldom occur on cloudy nights, because the moisture in the clouds holds the heat waves from the earth, which keep the air warm and prevent the condensation of water vapor. Dust and smoke have much the same effect as clouds, and for this reason smoke is sometimes used to prevent frost. Wind also prevents frost, the air being kept in such rapid motion that little or no moisture is deposited. Moisture, dust, and smoke all tend to prevent radiation. In dry air radiation takes place rapidly, and consequently descrt countries are nearly always cold at night, though warm in the day.

31. Solid Substances in Air.-Dust particles may often be seen in the air, and especially is this true in dry weather, when they beeome so numerous as to be very disagreeable. Rain washes most of the dust from 
the atmosphere, leaving the air fresh, clear, and cool. Along with the dust particles, and often carried by them, are many small bodies called Bacteria. They are living bodies, but such small ones that they can be seen only by means of a good microscope. Some bacteria cause disease in plants and animals, but others are very beneficial to both, as you will learn later on. Notice the mold which forms on starch paste when it is left open to the air. This mold is caused by bacteria, which feed on the paste. If some substance poisonous to bacteria be mixed with paste no mold will form, and the paste keeps till it dries up. Oil of wintergreen is poisonous to certain bacteria, and is much used for preserving starch paste.

32. Meteorology.-Wind, rain, and sunshine do not come and go by chance; their movements are regulated by laws as exact as those changing day to night and night. back to day again. By studying these laws we may learn when to expect a change of weather. Scattered over our country are many weather bureaus, where men employed by the government are constantly watching and recording the changes and movements of sunshine, wind and rain, which changes go to make up what we call weatura. It is very true that man cannot control the coming and going of sunshine, wind, and rain, but the successful farmer knows how to regulate his farming to suit the weather, and is always prepared to meet the changes which are eonstantly occurring. Some knowledge of METEOROLOG-the seience of the weather-is necessary in successful farming. This knowledge usually comes from years of experience and 
observation on the part of the farmer, but now the weather bureaus supply, for the asking, information which has been collected as the result of years of patient labor. Each farmer should, however, keep a record for his own farm or locality, and if the work be done carefully and systematically, it will prove of value not only to him, but to his community and to his children after him.

\section{Questions}

1. Why is carbon dioxide important to growing plants? 2. Why is there usually more carbon dioxide. in the air of cities than in the air of the country? 3. What is ammonia? 4. What is water vapor? 5. Which contains the more water vapor, warm or cold air? 6. When the water vapor in the air condenses on the surface of the earth, what is it called? 7. How is frost formed? 8. How does dense, moist air behave towards the heat waves from the earth? 9. Why are the tops of high mountains colder than the country below? 10. What do the dust particles in the air often carry with them? 11. What is meteorology? 


\section{PAR'T II.-PIAAN'TS}

\section{CHAPTER VI.-Plasts AND TheIr Sred}

33. Annuals, Biennials, and Perennials.-Most of the plants cultivated on the farm are grown from seed; a few grow from cuttings, and a few from roots, but the more important farm crops all grow from seed. Plants are often divided into three groups-annuals, biennials, and perennials. These words refer to the length of the plant's life. Axvuals are plants living about one year; BIENNIALs, plants living about two years; and PERrNvials, plants which live on year after year for an indefinite period. Annuals grow rapidly to their full size, produce a crop of seed, and die all in about onc year's timic. Bicnnials often reach their full size in one year, but do not produce seed till the second year. After producing a crcp of seed they also die. These two classes of plants produce only one crop of seed. Perennials have no fixed lifetime-some such as oak trees live to be hundreds of years old, others live only a few years. Most perennials produce seed each year; others only at longer intervals.

34. Seed.-Most farm crops grow from seed; corn, oats, wheat, cotton, rice, and tobacco all come from the planting of seed. Each crop produces but one kind of seed, and this seed when planted in turn produces 
again the crop. There is never a mistake-corn comes from corn seed and wheat from wheat seed with abso-. lute certainty.

A seed is the egg from which a plant is hatched. An ordinary seed may well be compared to an egg. It consists usually of an outer shell protecting the soft inner portion, which is really the young plant folded up. A sitting hen warms her eggs with the heat of her body till the necessary changes have taken place in the egg, then the chick begins to stir, and soon bursting the shell comes into the world a living animal. The apparently lifeless egg, when warmed by the hen, is changed into a living chicken. The equally dead-looking seed, when warmed in the soil by the sun's heat waves, bursts its shell and becomes a living plant. Most plants drop their seeds late in the fall, when a comparatively small number of heat waves come to the earth from the sun, and the earth is in consequence cool. The seed lies on the surface of the ground all winter, the soft little plant folded up within being protected from the cold and wet by the hard outer shell. In the spring, when the heat waves begin to strike with more and more force on the earth's surface, the plant folded up in the seed begins to feel their effect, and soon bursts its shell and begins its life as a young plant. The warmth of the hen's body seems all that is necessary to hatch the egg, but other things besides heat are necessary to hatch out a seed. Seeds may be kept in a warm, dry place for years, and yet never sprout; but so soon as they are moistened they will, if alive, begin to sprout and grow. Water, then, as well as heat, is necessary for the sprouting of 
seeds. A seed planted deep in the soil will not grow, no matter if supplied with water and heat; but on or near the surface it sprouts. Air, then, must also. be necessary for the sprouting of seeds. By means of a few simple experiments, described at the end of this chapter, any one may prove for his own satisfaction that. water, heat, and air are necessary to sprouting seeds.

$A$ sced contains not only the young plant or embryo, but a sufficient. store of food to nourish it until it can take its food from the soil. Take a fresh bean and notice how it is divided into two equal parts, joined at one end by a small stem. 'These two parts arc called the SEED LEAVus, and contain a store of food suflicient to nourish the growing plant until it ean feed itself through its roots. lig. 1 shows a young bean plant recently spronted; $c$ c are thic seed leaves, and as the plant grows larger they grow smaller till they are finally.

used up and only a wilted slicll re-centlysprouterl. Young used up and only a wilted sliell re- plant just whowing mains, which soon falls off from above ground. ce sevel the stem.

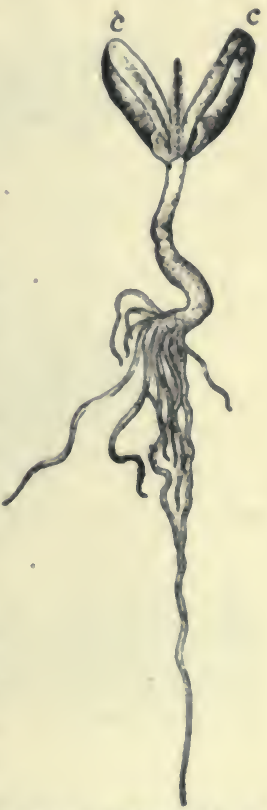
ins from pliotokraph.)

All seeds are provided with a store of food for the use of the young plant, for young plants, like young animale, are not able to take care of themselves just at first. 
The nourishment for the young plant is not always stored in the seed leaves as it is in the bean, but often surrounds the young plant, as in the corn seed. as shown in Fig. 2.
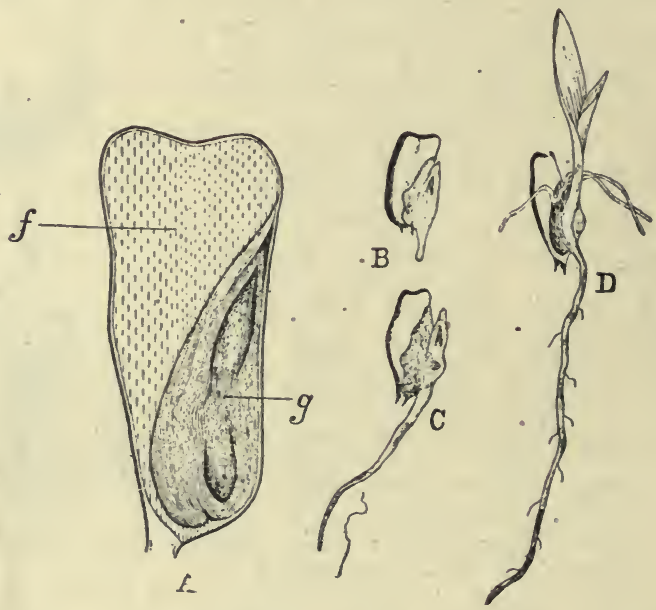

FIG. 2.-Grain of corn showing stages of germination: $A$, section of ripe seed enlarged; $f$, seed-food, the portion that nourishes the young plant; $g$. germ of seed. $B$, showing seed just sprouted; $C$, showing sprouting further advanced. $\Gamma$, showing spronting still further advanced; young plant just showing above ground. (Original drawing from photographs.)

\section{E.TIERIMENT}

Fill an ordinary decp plate with sand or common soil, and moisten it thoroughly with water. Then cut a piece of flannel cloth just large enough to fit in the plate, and morsten thoroughly. Cover the soil with the damp flannel cloth, and over it scatter the seeds to be tested. Cover with another piece of damp cloth. Finally cover the whole with another plate, and set auay in a uarm place, where the temperature is about $80^{\circ}$. Fig. 3 shous a cut of this arrangement. Keep the flannel and soil damp but not uet; if too much water is addod, the seeds will rot. If the cloths are kept dry, the seeds will not sprout at all, 
nor will they sprout if the temperature is kept below $40^{\circ}$ or above $116^{\circ}$. If some of these same secds be plinted decp below the surfuce of the soil, a foot or more, they will never come up,
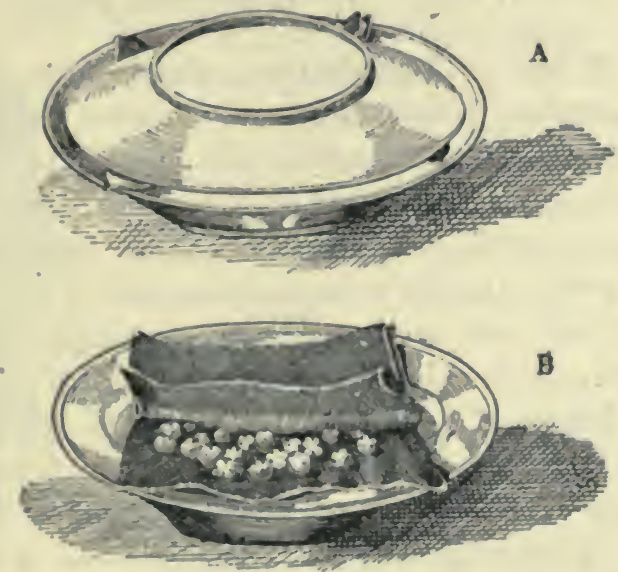

Fig. 8, - simple apparatus for rermlnatlug send: $A$, eluesd ; $B$, open

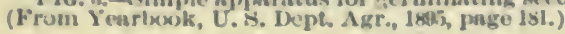

but on the surface they sprout readily. From experiments such as this sce learn that sceds must be supplied uith certain quantities of heat, water, and air before they can sprout.

\section{Questions}

1. What is an annual? 2. What is a biennial? 3. What is a perennial? 4. How many crops of seed does a biennial plant produce? 5. How often do most perennials produce seed? 6. How is a hen's egg changed to a chicken? 7. How does heat affect most seeds ? 8. What is necessary besides heat to sprout seeds ?

\section{PROBL.EM}

Make a list of all the plants you know in you neighborhood, and divide them into annals, biennials and perennials. 


\section{CHAPTER VIİ-PARTS of a Plant}

35. Organs of Reproduction.-Many plants, as you know, produce flowers, fruit, and seed; but these parts, or organs, as they are called, have nothing to do with feeding the plants which produce them. From the flowers come the fruit and sceds; the seeds produce other plants like the ones producing them; hence, the flower, fruit, and seed are called the ORGANs OF REPRODUCTION, because they reproduce other plants.

36. Organs of Vegetation.-Most plants which grow on the farm have three distinct parts, two of which, the stem and leaves, are above ground and may be readily seen. The third part of the plant-its roots-is buried beneath the surface of the soil, and can only be seen by digging down in the earth or ly pulling the plant up. These three parts, or organs, are necessary to the health and growth of a plant. Cut off a plant's roots and it soon withers and dies. Cut off all its leaves and its growth is checked, and often the plant is killed. Cut away the stem and the leaves soon die; the roots, however, if left in the ground, may put forth a new stem. Each of these three organs has its work to do in feeding the growing plant. They are called organs of VEGETATION.

When the young plant bursts its shell and begins to grow, one part, the root, grows down into the earth; the other, the stem, grows in the opposite direction, towards the light. Fig. 2, page 36, shows how a grain of corn 
sprouts. The plant never makes a mistake in starting to grow; the roots always go into the soil and the stem and leaves to the light and air above. Why they do this we do not know, but we do know that the roots keep on growing into the soil, spreading out in search of food

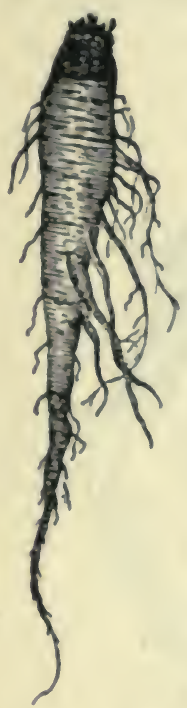

- Fic. t.-Tup). root of salslfy: flewhy roue. (Orl: glnal drawing from photo: graph.) and water and taking a firm hold to support the stem and leaves above. It first, as you have been told, the food. stored up in the seed feeds the young plant. Iater on, when the plant becomes stronger, it feeds itself through the roots and leaves.

37. Roots.-We all recognize the great variety of leaves produced by different kinds of plants, but the roots buried beneath the ground are less familiar, and while not nearly so varied in appearance as the leaves, are of many kinds and shapes. Many plants are provided with one large main root, which goes deep into the soil. This root is called the TArroot, and its branches are called natrin roots. Fig. 4 shows the taproot of a salsify plant. When the taproot is enlarged, as in the salsify and turnip, it is called a FLESHY noor.

Instead of one main root, many plants have a number of roots of equal size. Fig. 5 shows the roots of a corn plant. Such roots are known as CLUstrened or crows roots. When they are enlarged, as in the sweet potato, Fig. 6, they are called tuBtrous. Iateral, or side 
roots, and the younger portions of main roots are covered with fine thread-like branches that are called nоoт HAIRs. The little roots are so small and delicate that they are difficult to find. But they may be seen by sprouting radish seed as described in experiment on

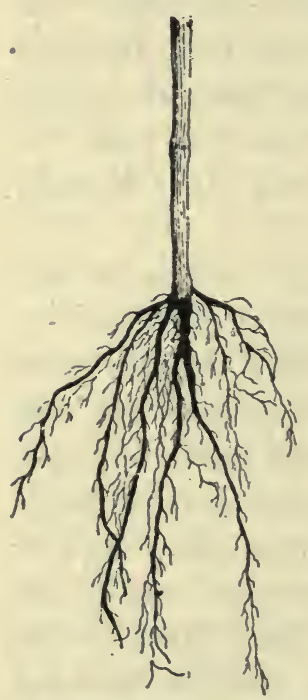

FIG. 5.- Roots of a young corn plant; clustered or crown roots. (O riginal drawing from photograph.)

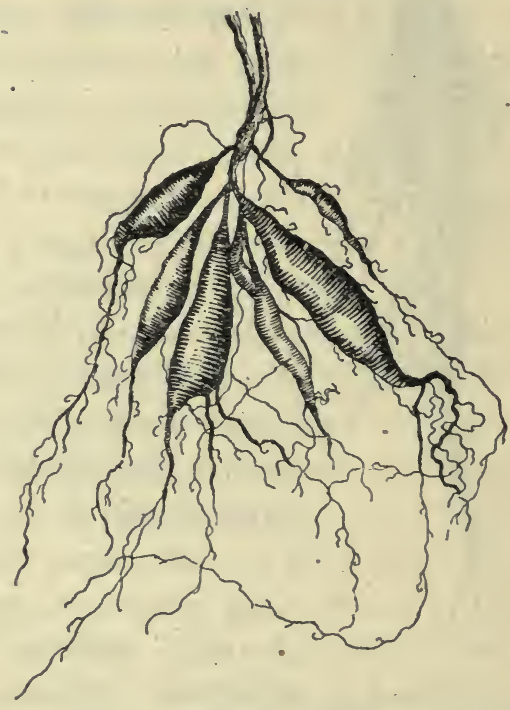

Fig. 6.-Tuberous roots of the sweet potato. (Original drawing from photograph.)

page 36. Fig. $7 \mathrm{~A}$ șhows a young radish plant sprouted in this way; the root hairs show like fine threads. Fig. 7B shows a young radish plant pulled from the soil: Here the root hairs are covered by particles of soil, and if they are washed off the ront hairs are destroyed. The root hairs are delicate tubes through which the plant draws much of its food and water. Fig. 8 shows the 
root hairs of an oat plant highly magnified. Water easily passes through the walls of the root hairs, and from them passes on into the main roots, and finally into the plant stem. Each root hair is like a miniature well, through which water rises into the main roots of the plant. When a growing plant is taken from the soil

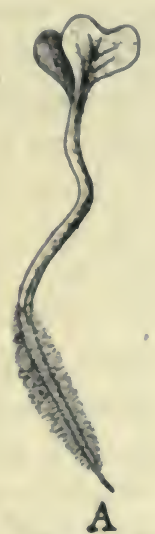

Fir. 7.-Young radish plasst: $A$, younk plant мpтииted ax dекс rlbed In experlment, p. sess; $B$, young plant pulled from the woll. (O) rlate nal drawlinge from photo. kraphx.)

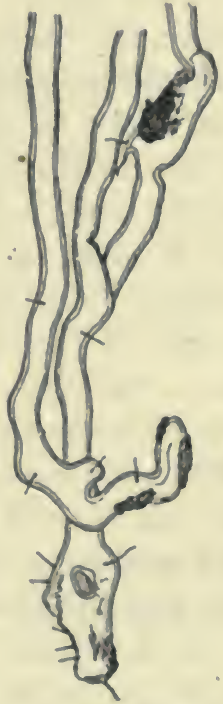

Fig, 8-IRout hadrs of txat plant magnifled wo llines: show:s anall $x$ a) helng diswolven! hy waje of the roots. (From Siscline's Fixp. Pliys. d. l'flarzen.

and replanted it nearly always wilts, taking several days to revive. It wilts because many of its root hairs are destroyed, and consequently its water supply is lessened. In time new root hairs are formed and the plant revives.

Roots are useful to plants in two ways: First, they 
supply the porticn of the plant growing above the ground with a firm support. Second, they supply the plant with much of its food and water.

The root hairs and smaller roots supply most of the food and water. The larger and stronger roots serve as carriers of food and support the growing plant.

38. Stems.-Stems are more varied in appearance than roots. In large plants, such as trees and shrubs, the stem consists of a main upright portion called the TRUNK, which is provided with a number of branches ealled LIMBS, and they in turn are provided with branches called Twigs. In most plants the stems are upright, and the general dircetion of the limbs is the same. But there are many plants provided with horizontal stems growing along the surface of the soil; other plants are provided with drooping stems, which, after reaching a certain height, turn towards the earth again. Still others are provided with twining stems, and can only grow upward when provided with a support around which they grow. But whatever the shape and size of stems they all serve the same purpose. They bear the leaves, flowers, fruit, and seed of the plant, and they serve to distribute the food and water taken in by the roots and leaves.

39. Leaves.-Leaves are more varied in size and shape than either the stems or roots, but most leaves have one striking point in common-namely, their color. With a few exceptions all living leaves are green, and a loss of this color only occurs through disease or death. The stems of young plants and the tender twigs of older plants are often as green as the leaves. The veins 
of leaves are really a continuation of the stem. Fig. 9 shows veins in a leaf of beetleweed.

The green color of leaves is due to the presence of a substance called CHLOROPHYL, or LEAF-GREEN, which

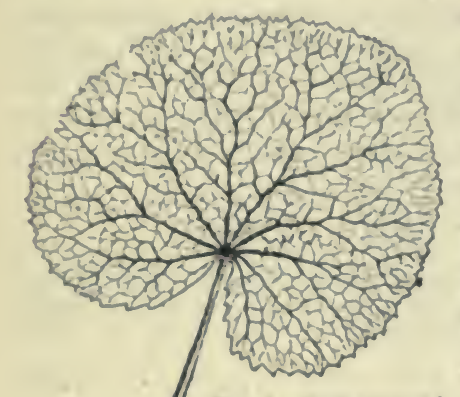

Firs. 0.-Veins In lone of beetleweerl (fininx n phylla. J.o) (Orlglnul drawing from unture.) is found in the leaves of all living plants that draw their food from the soil. This green coloring matter, chlorophyll, has much to do with making the different compounds which go to make up the plant. In the autumn, when the first frost falls, the leaves of plants lose their green color, taking many shades of red and brown. This change in color is an indication that their life is orer and that they are of no more use to the plant. When the leaves die plant-growth ceases till a new crop is formed in the spring.

\section{HXIPERIMENT}

Fill a small box with earth and in it plant a feio secds. After the plants have begun to grove, cover them with a box having an opening to the light on one side only. After a time notice how the young plants groie toucarls the light. Remote the box and the plants change their dircetion and grose upurards.

\section{Questions}

1. Into what three parts may a plant be divided? 2. What are these parts called? 3. How many of these parts can you 
see on a young plant? 4. Suppose the roots of a plant are cut off, what happens to the plant? 5. What are the flowers, fruit, and seed of a plant called? 6. Why are they so named? 7. When a young plant begins to grow, do all oi its parts grow in the same direction? 8. Which part grows into the soil and which towards the light? 9. What is the main root called? fo. What are its branches called? 11. What sort of roots have turnips? 12. What do we call roots like the sweet potato? 13. What are the stems of trees called? 14. 'T'ell in what different ways the stems of plants grow. 15. What purpose do they serve? 16. In what ways are all leaves alike?

\section{PROBLEM}

Make a list of all the plants you know that have fleshy roots. Make a list of all the plants you know that have fibrous roots. 


\section{CHAP'TER VIII.-CoMposition of Plants}

40. Moisture.-When fresh; green grass is cut and dried in the sun it withers and dies, losing much of its original weight, and forms what is called hay. If dry hay is ground up fine and carefully dried in an oven or over a slow fire, it loses still more weight, and in time becomes perfectly dry. Plants dried by the sun and air are said to be AIR-DRIED, and those dried by artificial heat are said to be CHEMICALLY-DIRIED. The reason plants lose weight when they are dried is because the moisture in the plants is driven off by the heat. To prove that this is true take any convenient dish, fill it with green plants, and heat it gently over a slow fire. When the dish becomes thoroughly warm hold some cool object, such as a cold, clean plate, over it and seo how the moisture condenses on the surface.

Fresh grass eut and dried in the sun loses threrfourtls or more of its original weight, and when artificially dried loses 80 per cent or more of its original weight. Most farm crops and trees are made up of from three-fourths to four-fifths water, and some plants contain even as much as 90 per cent water. Different plants, and different parts of the same plants, contain different amounts of water. The seeds appear to be perfectly dry, yet if they are ground up and heated they lose about one-tenth of their weight, which is moisture. Wood when first cut is said to be green, and though apparently dry, contains moisture, most of which is lost. 
when the wood becomes seasoned. Fresh young plants and the leaves of trees contain large amounts of water, 75 per cent or more. The trunks of trees and the stems of older plants contain less moisture, usually less than 50 per cent. Seeds contain less moisture than any other part of the plant, usually from 10 to 20 per cent.

41. Dry Matter.-The part of the plant that remains after it is dried is called DRY MATTER, and makes up, as we have seen, from one-tenth to one-fourth of the original weight of young plants. If dried plants are set on fire they burn, and only a little gray powder remains. This powder is called ASH or MINERAL MATTER. When plants are burned, most of the dry matter disappears as smoke and gas, and this part is called the volatile or CombUstible aratter. The amount of dry matter in different parts of the plant depends on the amount of water. The more moisture a plant contains the less dry matter, and the less water the more dry matter.

42. Volatile Matter.-This is the portion of the plant that is changed into gas when the plant is burned, and is often called ORGANIC MATrER. Volatile matter is made up of a number of substances, which we may divide into two groups, those containing nitrogen and. those without nitrogen. There are a number of nitrogen-containing substances in plants, but we shall call them all by one name, proteis. There are also a great many substances in the plant which contain no nitrogen, and those we shall call NoN-Nitrogevous. The amounts of protein and non-nitrogenous substances vary in different plants, and in different parts of the 
same plant, to as great an extent as do the water and dry matter. Peas, beans, and clover contain more protein than hay or straw. The seeds of beans and peas contain large quantities of protein, while the seeds of wheat and corn are made up principally of non-nitrogenous matters.

43. Protein.-The nitrogen-eontaining substances of plants are all compounds which are made up of five elements-carbon, hydrogen, (aygen, nitrogen, and sulphur-with sometimes the addition of very small quantitics of another element called phosphorus. The first five of these elements are called the organic elements, beause they make up such a large part of all organic matter. 'Their names are often abbreviated by writing simply the first letter of the name, thus: C for carbon, II for hydrogen, O for oxygen, $N$ for nitrogen, and $S$ for sulphur. 'These five letters make a word, CHONS, which may help one to remember how the nitrogenous matter of plants is made up. 'There are a number of different nitrogen compounds in most plants, but they are somewhat alike, and we may properly call them by one name, protein; just as we call the inhabitants of this country by one name, Americans. Albumen may be mentioned as one of the most valuable compounds that make up protein. The white of an $\mathrm{egg}$ is pure albumen, and is the best example of an silbuminoid.

Four of the organic elements, C, H. $\mathrm{O}$, and $\mathrm{N}$, were described in Chapter III. 'The fifth element is suLगHบี.

44. Sulphur.-This element is a solid substance, and is probably better known as brimstone. Sulphur is 
widely distributed both in the vegetable and minera?. kingdoms; all plants contain sulphur, and it occurs in large deposits in some parts of the earth. When eggs decay the sulphur in the protein unites with hydrogen and forms a gas called hydrogen sulphide, which has a very disagreeable odor. It is the formation of this gas that makes decaying eggs so disagreeable.

\section{Non-Nitrogenous Compounds.-In all plants} there are a number of organic compounds that contain no nitrogen; such compounds are largely CARBoHYDRATES. They are made up of carbon, hydrogen, and oxygen. The word carbohydrate means carbon combined with hydrogen and oxygen in the proportion to form water. 'The Greek word for water is hydor, so we speak of a substance combined with water as a IiYDRATE. Here we have carbouhydrate or carbohydrate: Starch, sugar, gum, and woody matter (cellulose) are all substances containing no nitrogen, and are made up of $\mathrm{C}, \mathrm{H}$, and $\mathrm{O}$. They are consequently carbohydrates. These four compounds make up a large part of all plants, and are found in varying quantities in different plants and different parts of the same plant. Sugar is found in the stem of sugar cane and sorghum, in the roots of sweet potatoes and beets, in the fruit of many plants, and small quantities are found in the seeds of most plants. Starch is found in the leaves of trees and the stems of young plants, in the roots of many plants, notably the sweet potato, and in the tubers of the Irish potato. The grains of many seeds contain quantities of starch; corn and wheat contain about 70 per cent starch. Woody matter makes up the stem and 
bark of most plants. Besides the carbohydrates, fat or oil is found in plants, principally in the seeds: for instance, the castor-oil bean and cottonseed

\section{EXPERIMENT}

Cut some fresh grass; weigh it and dry it in the sun. After it is dry treigh again and notice hor much it has tost in weight. Now set it on fire and allow if to burn; reeigh the ash. Calculate the per cent of both moisture and ash

\section{Questions}

1. How is hay formed? 2. Why does hay weigh less than the grass from which it was cut? 3. What happens to hay when heated by fire? 4. Which contains the more moisture, a plant or its seed? 5. When moisture is dried out from a plant, what is the remainder called? 6. How is dry matter made up? 7. That part of a plant which disappears when the plant is burned is called what? 8. Into what two classes of substances ean organic matter be divided? 9. Of what five elements is the nitrogenous matter of plants made up? 10. What are these five elements ealled? 11. In what parts of the p'ant is protein usually found? 12. Give an example of a nitrogenous substance. 13. What are the best known non-nitrogenous substances found in plants? 14. What three elements make up carbohydrates ?

\section{PROBI.FMS}

1. If a certain hay contains 10 per cent of water, how many pounds of dry matter does a ton of such hay contain?

2. Five hundred pounds of corn contains 350 pounds of starch, what is the per cent of starch?

3. Five hundred pounds of oats contains 50 pounds of protein, ealculate the per cent of protein. 


\section{CHAPTER IX.-Composition of Plants} (Continued)

46. Mineral Matters or Ash.-The ashes of plants are - made up of a number of elements, which are combined - into various compounds. Of the organic elements, carbon, oxygen, sulphur, and phosphorus are often found in the ashes of plants and sometimes nitrogen and hydrogen. Besides these elements the ash contains silicon, chlorine, potassium, sodium, calcium, magnesium, iron, manganese, and minute quantities of several other elements. These elements are all combined in various ways with each other, none of them being found alone.

47. Phosphorus.-This element, which is a solid substance, has such a tendency to combine with oxygen that it is never found alone. Ordinary phosphorus must be kept under water to prevent its oxidizing. When phosphorus and oxygen unite, the union produces much heat, and this fact is taken advantage of in the manufacture of matches. Phosphorus is usually found combined with calcium and oxygen, in which form it is variously called CALCIUM PHOSPHATE, PHosPHA'TE OF LIME, and BONE PHOSPHATE. This compound makes up a large part of the phosphate deposits of the world. Some form of phosphorus exists in the bodies of all plants and animals, and neither can grow without a supply of this element. The combined phosphorus in 
soils and plants is usually spoken of as pHospuoric ACID.

48. Silicon.-This is a solid element, which, combined with oxygen, makes sand, or quartz rock. Silicon never occurs free, but always combined with some other element, usually oxygen. Its compounds are called siLic.ITEs. Corinbined with oxygen and other elements, notably potassium and sodium, it is found in the ashes of plants.

49. Chlorine.-This element is a gas with a very disagreeable odor. It is very active, combining readily with many other elements. With sodium it forms salt, which is widely distributed over the earth. Compounds of chlorine with other elements are called chLorides, and they are found in the ashes of all plants.

50. Potassium.-This is a solid element, which always occurs in combination. It combines very readily with water, and forms what we know as LYE or POTASH LYE. It also combines with chlorine, forming a compound resembling salt and known as potassium chuonide, commonly called muriate of potash. On the farm this compound is much used as a fertilizer. It combines with oxygen and carbon to form rorassium carbonatr. In some form it is found in the ashes of all plants.

51. Sodium.-This is another solid element, which closely resembles potassium. It never occurs free, but always in combination. It forms compounds very similar to those formed by potassium. With water it forms SODA LYE; with chlorine, salt; and with carbon and oxygen, SODIUM CARBONATE. It uccurs in some form in 
the ashes of all plants. Wood ashes are often leached with water and the compounds of potassium and sodium which dissolve out, form common lye, which is used to make soap.

52. Calcium.-A solid element which never occurs in a free state, but always combined with some other element. With earbon and oxygen it forms a compound which is properly known as CALCIUM CARBONATE. When this compound is heated very hot the carbon and part of the oxygen are driven off as carbon dioxide, and the calcium and part of the oxygen remain as QUICK LIME. Quick lime takes up water very rapidly and changes to SLACKED LIME. Calcium in some form is found in the ashes of all plants.

53. Magnesium.-This element is a metal of a light silver color. It unites with oxygen when heated, and the union gives a very brilliant light, known as MAGNEsiUm LIGHT. This light is used for making photographs at night, and the magnesium used for this purpose is called FLASHLIGHT POWDER. In the ashes of plants magnesium always occurs combined with some other element, and never as a metal.

54. Iron.-This element is so well known that it scarcely needs a description. It is found in the ashes of all plants combined with some other element. The green coloring matter of plants contains iron.

55. Manganese.-This is a metal that somewhat resembles iron. It is seldom found alone, but usually in combination with oxygen. Its compounds are similar to those of iron, and occur in small auantities in the ashes of all plants. 
Minute quantities of a number of other elements are found in the ashes of plants, but they are of no importance in agriculture, and need not be mentioned.

The following diagram shows in a condensed form how the plant is built up:

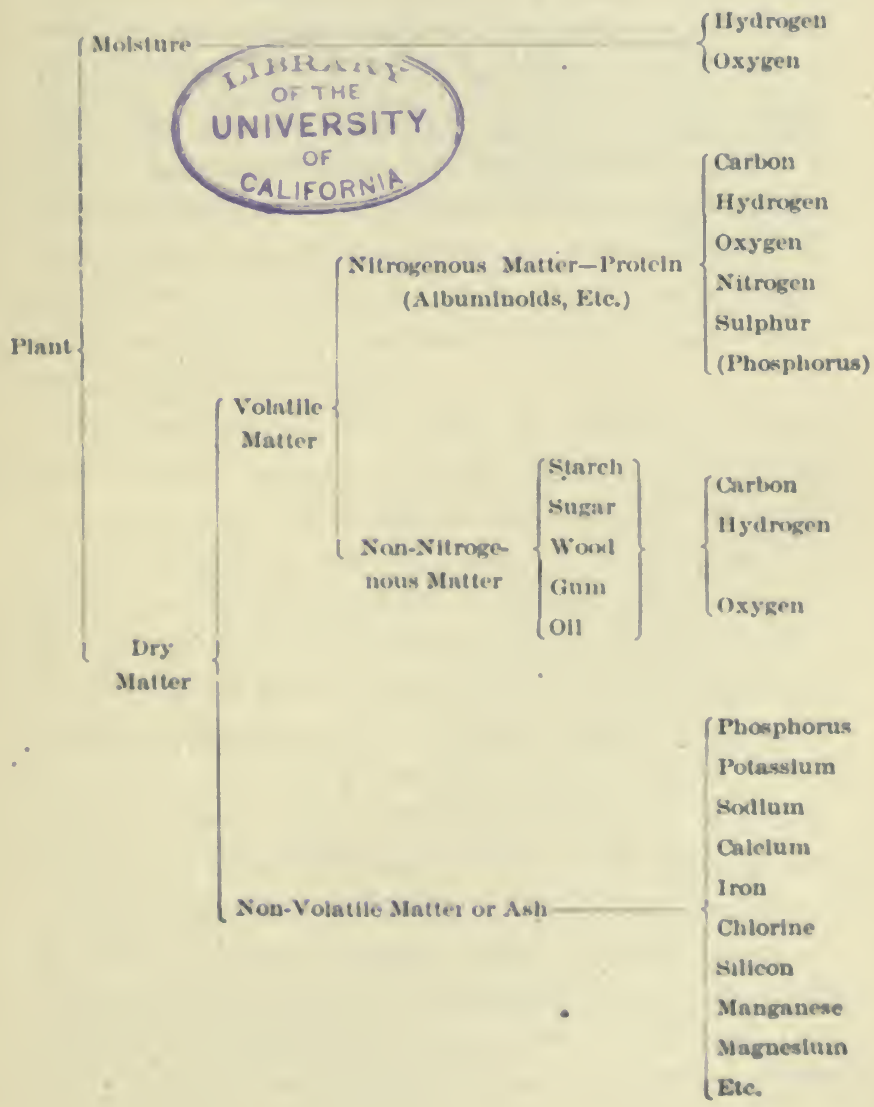




\section{Questions}

1. In what form are elements found in plants? 2. Name twelve elements that make up most of the compounds in plant ashes. 3. Is phosphorus a liquid, solid or gas? 4. What household article is made up in part of phosphorus? 5. With what two elements is phosphorus usually found combined, and what is the compound called? 6. When silicon is combined with oxygen, what is formed? 7 . What are compounds containing chlorine called? 8. In what combinations is potassium found? 9. Describe another element that resembles potassium. 10. Describe calcium. 11. What is the compound of calcium with oxygen called? 
CHapter X.-The Food the Plant Takes from THE SOIL

56. Water.-Most plants have only two sources from which to draw their food-namely, the soil and the air. From which of these sources do they draw their water? Seed will not sprout in a perfectly dry soil. Deserts produce almost no plants, and in time of continued drought plants droop and finally die. It is evident that soil to spront seed and grow plants must contain water; and from thise facts we learn that plants draw their water supply from the soil.

By remembering that about is per cent of most young plants is moisture, we may form some idea of the vast amount of water taken from the soil by many crops. Suppose an acre of groun. produces a crop of green clover weighing 12,000 pounds, or 6 tons; about 80 per cent of this is water, or 9,600 pounds or 4.8 tons. But this is not all the water an acre of clover requires while it is growing. You may drink a glass of water in the morning, but in a few hours you are again thirsty and want more water. So with the elover; it is constantly drinking more water, and if not supplied the crop withers and in time dies. Now, what becomes of all the water which plants drink up from the soil? They can hold only a certain amount, and as they are constantly drinking it in, some must be given off. If you will notice carefully the leaves of plants you will 
find that the upper side, which is the one turned towards the sun, is different from the lower side. By examining the lower side with a good magnifying glass you will notice many small openings in the leaf. These little mouth-like openings are called sтomata, and have the power of opening or contracting. Fig. 10 shows some
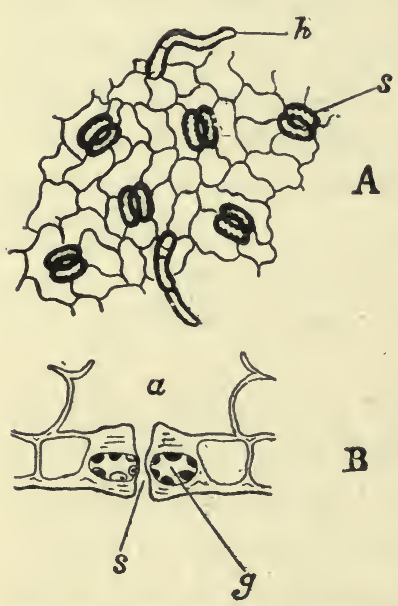

FiG. 10.-Stomata, or breathing pores: $A$, under side of leaf highly magnified; stomata shown at $s$; small hairs in leaf at $h$.

$B$, section through stom ata, highly magnified; 8 , mouth of stomata; $a$, air space in the leaf; $g$, cells which as they expand or contract, open or close the stomata. of course, varies, but most growing crops give off large quantities of water. On a dry, hot day grass plants have been known to exhale their own weight of water in twenty-four hours. Experiments conducted in Germany have shown that plants, for every pound of dry matter, require, during the time they are growing, 
about the following amounts of water: Oats, $3 \gamma 6$ pounds of water to one pound of dry matter; wheat, 338 pounds of water to one pound of dry matter; red clover, 310 pounds of water to one pound of dry matter. Take as an example the clover crop already mentioned, which weighed 12,000 pounds. As 80 per cent of this is water, we have 20 per cent dry matter, or 2,400 pounds. If one pound of dry matter requires 310 pounds of water, the 2,400 pounds must require 744,000 pounds of water, or $3 \% 2$ tons, or about 75,000 gallons. At this rate, to produce about one ton of elover hay more than 300 tons of water are needed.

The moisture in the atmosphere cannot be taken up by plants unless it first passes into the soil.

A plant wilts because the leaves give off more water than the ronts can supply.

57. Nitrogen.-From the soil plants draw most of their supplies of nitrogen which is combined in the organic matter of the soil. Nitrogen, if not the most important, is one of the most important of all the plant foods, and we shall have more to say about it when we come to write of soils.

58. Mineral Matter.-The clements which make up the ashes of plants come, of course, from the soil, as they are not found in the atmosphere or largely in water. Although the amount of mineral matter contained in plants is very small, a proper supply is absolutely necessary. All soils contain the necessary elements of plant food, but in many soils the supply is small, and in some soils the elements are so combined. as to be unfit for plant food. When such is the case 
they are said to be unavailable. For instance, nitrogen, which makes up four-fifths of the air, is a very important plant food, but plants cannot take in free nitrogen gas; it must first be combined with some other elements, usually hydrogen and oxygen, before it can become plant food. Phosphorus is another valuable plant food, and when combined with certain quantities of calcium and oxygen, is readily taken up by plants, but alone or combined with larger quantities of calcium and oxygen it is not fit for plant food.

Nitrogen, phosphorus, and potash are three important foods that the plant takes up from the soil. A proper supply of these foods is often lacking in soils, so they are added in the form of fertilizers. Iron is another important plant food. It is necessary for the formation of chlorophyll, the green coloring matter of plants, which utilizes the carbon dioxide of the air in the formation of starch. As all soils contain a great abundance of iron it is not necessary to add it as a fertilizer. Calcium is still another important plant food. Soils usually contain an abundant supply of this element, but it is sometimes found necessary to add it to the soil in the form of lime. These foods-nitrogen, phosphoric acid, potash, lime, and iron-are necessary to the growth of plants, and no crop can be grown without a proper supply of them. Nitrogen, phosphoric acid, potash, and lime are the four most often lacking in soils, and to make up any deficiency they are added in the form of fertilizers. 


\section{Questions}

1. From what two sourees do plants draw their food? 2. What will becosne of a seed in a perfuctly dry soil? 3. Where do plants get their water? 4. What per cent of growing plants is water? 5. What becomes of the excess of water taken by the plant? 6. How is this water given off? 7. What is this process called? 8 . What are the openings in the leares called? 9. Where does the mineral matter in plants come from? 10. From what source does a dant draw most of its nitrogen? 11. What supplies mineral matter for plants? 12. What is chlorophyll? 13. Why are fertilizers sometimes added to soils? 14. When are plant foods said to be unavail. able? 15. When are plant foods said to be available?

\section{PROBLEMI}

If a crop of oats contains 1,000 pounds of dry matter, about how many pounds of water has the crop used during the time it was growing? 
Chapter XI.-The Food the Plant Takes from TIIE AIR

59. Carbon.-Plants, as you have scen, get their water and mineral matter from the soil. You would then naturally inquire whether plants get their carbon from the soil. Carbon in some form is present in all soils, but plants do not use this.carbon for food. It has been proven by experiments that plants cannot grow unless their leaves are supplied with air containing carbon dioxide gas, which you remember makes up a small part of the atmosphere. - Other experiments have shown that the leaves of plants absorb carbon dioxide from the air, take from the gas the carbon, and give off the oxygen. Men and animals reverse this process; they draw air into their lungs, where the oxygen of the air unites with the carbon in the blood, and is given off as carbon dioxide gas. Men and animals inhale oxygen and exhale carbon dioxide. Plants inhale carbon dioxide and rgive off oxygen. Animals cannot live in air containing much carbon dioxide. Plants cannot live without a supply of this gas. Leaves have often been called the lungs of plants, and in their manner of taking up food from the air they do resemble the lungs of animals. Breathing animals are constantly adding to the supply of carbon dioxide in the air; the leaves of plants are constantly absorbing it and returning to the air free oxygen. In this way plants aid in maintaining a balance, 
which means that the amount of carbon dioxide in the air remains always about the same.

The leaves of plants absorb carbon dioxide oniy in direct sunlight; on cloudy days the amount of gas absorbed is small, and at night the plant not only does not absorb any gas, but actually gives off carbon dioxide just as animals do in breathing. The amount of carbon dioxide thus given off is, however, very small compared with what is taken up under the influence of light.

60. Oxygen.-While the leaves of plants under the influence of sunlight take up carbon dioxide and give off oxygen, the roots of growing plants require a constant supply of free oxygen in order that they may grow. Seeds, you remember, require a supply of air before they will sprout, and it is the oxygen of the air that enables them to begin to grow. A seed supplied with only nitrogen gas will not sprout, no matter how perfect the other conditions. When plants are in bloom, and later on when they are forming seed, a constant supply of oxygen is necessary. Oxygen is then necessary for all growing plants from the beginning of their life to the end. The air, of course, contains an abundant supply of oxygen for all the needs of the plant above ground-that is, for the buds, flowers, and leaves. The spaces in soils, as you will prescntly learn, contain air, which supplies oxygen to the roots of plants. If for any renson the supply of air in the soil becomes exhausted the plant growth is checked.

61. Ammonia Gas.-Air contains minute quantities of this gas, which supplies to plants a small part of 
their nitrogen. This gas is not taken up through the leaves or stem, but through the roots. Rain water washes the ammonia from the air into the soil, where it may be changed to a form suitable for plant food. The amount of nitrogen thus supplied to plants is, however, quite small.

62. Nitrogen.-Some plants have the power of using the nitrogen of the air for food. There are, however, only a few varieties of plants that have this power, and of them we shall have more to say later on.

\section{Questions}

1. From what source do plants draw their supply of earbon? 2. How does carbon occur in the air? 3. In what form is earbon taken in by plants? 4. In breathing, what element is taken from the air by men and animals, and what returned to it? 5. What element is taken from the air by the leaves of plants, and what returned? 6. Why are the leaves sometimes called the lungs of plante? 7. Why is it necessary to loosen up the giound when planting seed? 8 . What parts of plants take up oxygen? 9. Does the air supply plants with any part of their nitrogen? 


\section{CHAPTER XII.-How Plants Grow}

\section{Water Enters the Plant Through Its Roots.-We} have learned in the, last chapters what kind of food plants require and where they get it. Now the question arises, How does the plant take up its food from the soil and air? 'Through its roots and leaves, of course, but how? The roots have the power of sucking the moisture from the soil, through their root hairs, as described on page 39. Each little root hair is a miniature well from which the water rises into the plant:

64. Mineral Matter Enters the Plant Through Its Roots.-Inst of the mineral matter in the soil is in the form of solids, and, before it ean enter the plant, must be dissolved. Under the head of leaching you were told how rain water dissolves various substances in the soil and carries them off to the sca. The water which the. roots of plants take in contains dissolved in it much mineral matter, usually in the form of salts. In this way the plant can drink in its food dissolved in water. But not all of the mineral matter is taken up by the plant in this manner. All plants, you know, contain a liquid called sap. No doubt you have all seen it oozing out of a cut in some tree or plant. The sap which goes. down into the roots can dissolve some minerals which water cannot, and it acts on the small fragments of mineral with which the root hairs come in contact. Fig. 8 , page 41 , shows how the root hairs are covered by fine particles of mineral matter, which are being dissolved 
by the sap. Oxygen is also taken up by the roots of plants, and nitrogen compounds dissolved in water also enter the plant through its roots.

65. Compounds are Manufactured in the Leaves.Through their leaves plants draw from the air supplies of carbon dioxide; through their roots they pump water and the salts it contains in solution; and from these compounds are made many substances that go to build up plants. Chief among these is starch, a substance with which every child is familiar, as it makes up a large part of many foods; wheat flour, corn meal, rice, and potatoes are mostly starch, every grain of which is manufactured in the leaves of the plant which grows them. The so-called starch factories of the world never make an ounce of starch. All they can do is to separate from the other substances with which it is mixed the starch that is actually made in the leaves of plants, and afterwards concentrated in the seed, root, or stem. The real starch factories are the green leaves of plants. Starch is made up of carbon, hydrogen, and oxygen-6 parts of carbon, 10 parts of hydrogen, and 5 parts of oxygen, or, as the chemist writes it, $\mathrm{C}_{6} \mathrm{H}_{10} \mathrm{O}_{5}$. Carbon dioxide the chemist writes $\mathrm{CO}_{2}$, two parts of oxygen to one of carbon; and water he writes $\mathrm{HO}_{2}$, two parts of hydrogen to one of oxygen. Il is evident that these two compounds contain all the elements necessary to form starch, and it is from them that the plant manufactures it. But how? We may mix water and carbon dioxide in varying proportions and under all sorts of conditions, but no starch results; we may mix six parts of carbon, ten parts of hydrogen, and five parts of oxygen, and 
subject them to all sorts of conditions, but no starch results. No chemist, however skillful, has ever succeeded in making starch. But the simplest little plant that grows knows the process, and every day in spring and summer, when the sun shines, is busy producing this useful substance. The chlorophyll in the green leaves of planits is the starch manufacturer, the leaf is the factory, and sunlight its power. When the waves of sunlight strike on the surface of green leaves the chlorophyll is busy converting water and carbon dioxide into starch; when the sunshine ecases the chlorophyll stops work. But stareh is not the only substance that is formed in plants. Sugar, oil, woody matter, protein, and various other compounds are likewise formed in the plant. No one knows exactly how these various compounds are formed in the plant, but it is very probable that most of them are formed in the leaf under the influence of sunshine. 'The various carbohydrates are probably made from starch. The protein compounds, besides carbon, hydrogen and oxygen, contain nitrogen and sulphur, which elements are drawn from the soil. But as to just how they are made into the various compounds found in plants we do not at present know.

66. Sap and Its Work.-The compounds formed in the leaves of plants are distributed by the sap to various parts of the plant as they are needed to build it up. As the plant grows older its various parts change in composition. 'The stems of most young plants contain starch, sugar, and nitrogenous substances, which, as the plant 
grows older, are found concentrated in the seed, and the stem is then composed almost entircly of woody matter.

\section{EXPERIMENTS}

Over a patch of green grass place a box or any other covering to exclude the sunlight. In a few days the grass vegins to lose its color and in time becomes white. If exposed to the sun again it in time regains its color and continues to grow.

- Select a growing leaf of bright green color, and without taking it from the plant cover a portion of the surface exposed to the light with black paper. The paper may be pinned or sewed on and should.fit close enough to cut off. all the light. In time the portion of the leaf under the paper loses its color, turning white. By cutting the paper into proper shapes, figures or letters may be formed on the leaf.

\section{Questions}

1. How do plants take up water from the soil? 2. How do plants take up their mineral food from the soil?. 3. What is the juice found in the stems of plants called? 4. In what way does sap aid in the growth of a plant? 5. In what form does the plant take its food from the air? 6. What well known substance is formed in the leaves of plants? 7. Of what is starch formed? 8. How are the compounds formed in the leaves distributed? 9. Are all parts of plants of the same composition? 10. As the plant grows, in what respect does it change in composition? 11. Where is múch of the plant food finally concentrated? 


\section{PART III.-SOILS}

\section{CHAPTER XIII.-How Solls are Made}

67. General Definition of Soils.-Many persons improperly speak of soil as "dirt." Sorl may be defined as the finely pulverized portions of the earth's surface in which plants may grow. Dirt means something unclean or filthy, and the rord should never be applied to soil. Soil, it is truc, may bccome dirty, but fresh, pure soil is clean and destroys clirt avd filth.

Soil, as the word is ordinarily used, refers to only the first 6 to 12 inches of the earth's surface. The portion below this depth is called the subsorl. There is usually a marked difference between the soil and subsoil.

Land is made up of soils, rocks, stones, and beds of mineral ore. Rocks are the great beds of hard minerals which may often be seen projecting through the soil and sometimes making up whole mountain ranges. Beds of granite, marble, sandstone. and limestone are called rocks.

Scattered through the soil are coarse, broken fragments of the rock masses called stones. Rocks and stones are made up almost exclusirely of mineral matter, and when they decay they form soils. It is hard to realize that the surfaces of rocks, which appear to be almost everlasting, are constantly being worn away to 
form soils, but such is undoubtedly the case. If a soil is examined with a good magnifying glass it is found to be made up of many small fragments of various shapes and sizes. The fragments resemble those which are formed when a coarse stone is pulverized, and this is just what has happened. Coarser fragments of stone have been broken up by various agencies, and the small particles resulting have formed the soil. We may put it down as an accepted fact that the mineral matter of all soils has resulted from the breaking up of rocks and stones.

68. Formation of Mineral Fragments in Soils.-Now, how is it that these apparently indestructible rock masses have been so broken up as.to form the great soil areas of the world? Soils are formed so slowly and quietly that we are not aware that such a work is going on about us, but soils are forming to-day just as they have been for thousands of years. The great soil-maker of the world is water, and it has several different methods of making soil.

69. Mechanical Action of Water.-More soils are formed by the mechanical action of water than by any other agency, so we may best consider it first.

The surfaces of all rocks, however smooth apparently, are filled with minute cracks. The surfaces of rocks long exposed to the weather are particularly full of irregularities; an apparently smooth rock, if examined with a magnifying glass, will show many cracks and joints. In io these cracks and joints water penetrates, and if the temperature becomes low enough; the water freezes, the cracks become enlarged, and often pieces of rock break off. Water always expands when freezing, 
and the force excrted is tremendous. Strong glass bottles are burt by freezing water, and even iron vessels are torn to pieces. The surfaces of rocks exposed to the weather in temperate climates are gradually being broken to pieces by freezing water. This action of water is called mechanical to distinguish it from the chemical action, which we shall consider presently. 'The mechani(al action of freezing water cannot, of course, form soils in warm countries.

Running water also helps to form soils. Notice thie stones in a creck or river bed. 'They are all worn smooth by the action of the water. Once these stones were rough and jagged in shape, but the running water has tumbled them about, grinding them together until all the rough edges are worn off. The small particles which result from the grinding are deposited by the water and go to form soils.

70. Chemical Action of Water.-Rain water dissolves many salts from the soil and washes the soil from exposed hillsides, but it compensates for this mischief by aiding in the formation of fresh soil. Rain water falling on the surface of rocks gradually dissolves away the portions soluble in water, and the insoluble parts crumble away and form soils. The great caves in limestone regions are the result of chemical action of water. Limestone is not very soluble in ordinary water, but water that has carbon dioxide gas dissolved in it-soda water is ordinary water containing carbon dioxide gas-dissolves limestone much better than ordinary water. Rain water dissolves the carbon disxide of the air, and also some that is formed from the organic matter in the soil. 
This water, containing carbon dioxide, enters the cracks and joints in limestone rocks, and, dissolving portions of them, gradually forms larger cracks and fissurcs which in time.grow into caves.

71. Other Soil Builders.-Plants also aid in the formation of soils. The fine root hairs of plants penetrate the cracks and crevices of rocks, and the root sap dissolves away portions of the rocks' surfaces. 'The small plants which grow on the surface of rocks. mosses and lichens, are especially active in forming soils. Their roots draw all their mineral food from the rock, and so gradually wear away the surface.

The oxygen and carbon dioxide of the air combine with many substances contained in rocks and, forming other compounds, help to wear away the original rock.

The minute bacteria in the soil also aid in breaking up rocks, but their action is chiefly on the organic matter which all soils contain.

72. Organic Matter in Soils.-So far we have considered only the mineral matter of soils, but it is by no means all of the soil. A soil made up exclusively of mineral fragments could no more grow crops than the original rocks from which the fragments came. Mixed with the mineral matter of soils are the decaying portions of plants and animals which make up its organic matter. As the organic matter of soil decays it forms a dark substance called HUMUs, which gives to many soils their dark color. The organic matter of soils is of great importance, and we shall have more to say of it.

Soils are then made up of two kinds of matter-organic and inorganic. The organic matter results from 
the decay of plants and animals; the mineral matter from the decay of rocks.

\section{EXPERIMENT}

When the weather is sufficiently cold, fill some glass bottle of concenient size with water an old ink bottle will ansicer. Stop up the mouth of the bottle and set it out to freeze. By the expansion of the water in freezing the bottle wiil bo broken.

\section{Questions}

1. What do we mean by the term soil? 2. 1s it proper to spenk of soil as dirt? Why? 3. To what part of the earth's surface does the word soil refer? 4. What is the difference between a rock and a stone? 5. What sort of fragments make up the greater part of all soils? 6. How are soils formed? 7. What substance is most active in making soils? 8. Describe the mechanical action of water in forming soils. 9. How does the chemical action of water help to form soils? 10. What other agents besides water form soils? 11. From what sources do soils draw their supply. of organic matter? 


\section{CHAPTER XIV.-Classification OF SOILS}

73. Transported Soils.-Soils seldom remain just where they are formed, for the same forces that form them also move them about. Water, the chief soil former, is also the chief soil transporter. Its

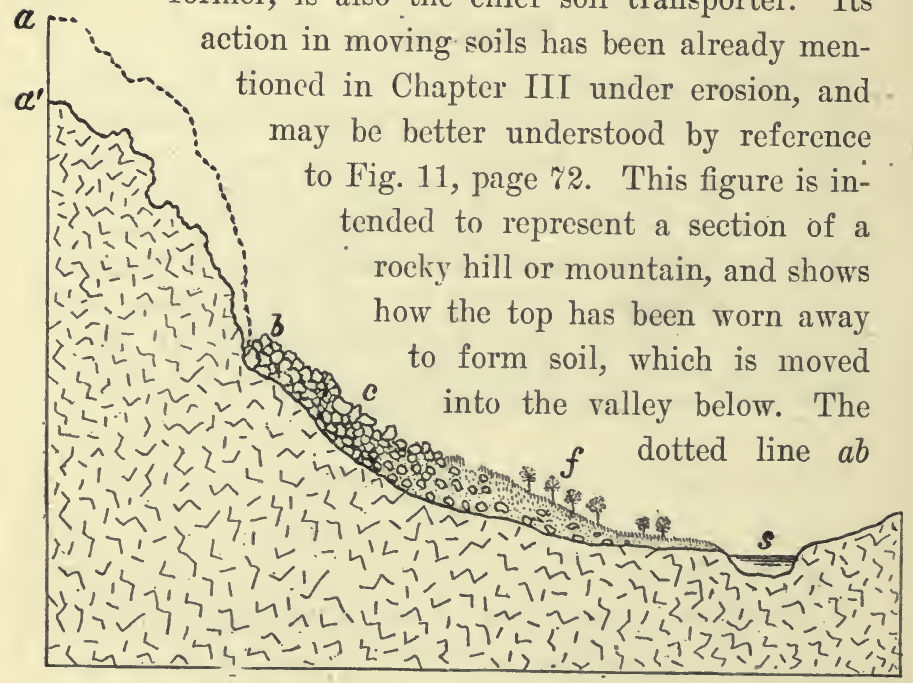

FIG. 11.-Erosion of hill or mountain side. The soil between the lines $a h$ and $a^{\prime} b$ has been washed away. $c$ shows coarse fragments; $f$, finer soil ; s, stream.

shows the original shape of the hilltop; $a^{\prime} b$ its present shape. 'The portion between $a b$ and $a^{\prime} b$ has been gradually worn away by frost and rain, and the particles washed by rain to the more level land below. The coarse fragments are the first to stop, and-as the ground becomes more level the finer particles are deposited from 
the running water and form the fertile soils of the river bottom. Many of the finest particles are washed into the river or ereek, shown at $s$, and are carried of to be deposited probably hundreds of miles away. Whenerer a river rises and floods the bottom lands, quantities of mud and sand are deposited on the flooded area. The mud and sand have come from hillsides, possibly many miles away, and in time they become part of the soil of the river bottom. Soils that have been moved from the place of formation are called TRANSPORTED SOILS, and are often a mixture of soils from many localities.

Wind storms also move soils about to a limited extent. You have all noticed the great clouds of dust blown about by high winds; and in very dry countries, such as the northern portions of Africa, the amount of soil moved is considerable. In our country, with the exception of one or two Western States, the amount of soil moved by winds is of small consequence.

In some parts of the world much soil has been moved, and is even now being moved, by glaciers, which are nothing more than rivers of icc. But glacial action is at present limited to a very small part of the inhabited world, and need not concern us.

74. Soils in Place.-Soils that remain where they are formed are called solLS IN PLACE. The soils that cover the slopes of hills and mountains for the most part belong to this class. Soils in place are seldom mixed with the soils of other localities, but result simply from the decay of the rocks about them.

75. Soils Classified According to Composition.-Soils, whether transported or soils in place, vary in the way 
they are made up. Different kinds of rocks when they decay make different kinds of soil. For convenience. the various kinds of soils have been given different names to indicate how they are made up. For instance, we have sandy soils, clay soils, muck, etc.

1. SANDy solls include all soils that contain large amounts of sand. Such soils are no doubt familiar to most of us.

2. Clay Soils include all those containing large amounts of clay. They may be easily recognized by their sticky character. Soils that are made up somewhat equally of sand and clay are called loams.

3. SANDY LOAMS are soils made up principally of sand and clay, but containing considerably more sand than clay.

4.. CLAY LOAMs are also soils made up principally of sand and elay, but containing more clay than sand.

5. Soils that contain much decaying organic matter are variously called HUMUS soILs, WOODS MOLD, or GARDEN SOIL. If this variety of soil also contains much moisture it is called PEATY SOIL, SWAMP MUCK, etc.

These five classes include all the soils commonly cultivated on the farm. There are other kinds of soil different from any of these, but they are not the ordinary farm soils.

76. Light and Heavy Soils.-Soils are often spoken of as LIGHT or HEAVY, but these words have no reference to the actual weight of the soil; they refer simply to the way these soils behare when cultivated. A light soil is one that is easy to cultivate; such soils are porous, and 
the plow or other implement of cultiration moves through then easily. A heavy soil is one that is more difficult to cultivate; it is stiff and offers more resistance to the plow or spade than a light soil. The socalled light soil, as a rule, contains much sand, and is by weight the heariest of all soils. The heary soils contain much clay, which is lighter than sand. Soils that contain much organic matter, peaty soils, are often light in both senses of the word. The following figures give approximately the weights of the different soils:

Dry Sand.... 100 to 120 pounds per cubic foot. Loam ....... 90 to 100 pounds per cubic foot. Clay ...... $\pi 8$ to $\$ 0$ pounds per cubic foot. Peat, etc.... 30 to 50 pounds per cubic foot.

77. Warm and Cold Soils.-According to their power of retaining the sun's heat, soils are ealled WMARM or cOLD. The amount of heat absorbed varies greatly in different soils, and depends on several conditions, but may be to some exfent regulated by careful sultivation. Plants for their proper development require a certain amount of heat in the soil. Seed will not sprout until the soil has become warmed to the required temperature, and most farm crops attain their most perfect development only in warm soils. Controlling, as far as possible, the amount of heat absorbed by soils is then a matter of the greatest importance, and with this end in view it is well to consider some of the conditions which infuence the sinount of heat in soils.

Water has the greatest influence on soil temperature; it is, in fact, the great temperature regulator of the 
world. In the second chapter the influence of the evaporation of surface moisture on the earth's temperature is discussed. This action may be compared to the evaporation of perspiration from the human body. The temperature of the human body is prevented from becoming too high by the evaporation of moisture given off through the skin. So it is with the surface of the earth, which may be called the skin; when it becomes too warm moisture is given off and its evaporation cools the soil. In very wet soils moisture is continually cvaporating, and in consequence such soils are usually cold. In dry soils, on the other hand, there is but little evaporation, and the soil through the sun's heat becomes warm. As a rule, the dryer the soil the greater the amount of heat absorbed. When no moisture is found the soil is turned into a desert.

The color of soils also influences the temperature. It is a well-known fact that dark clothes are warmer than white. So it is with soils-a dark soil is warmer than a light one:

The composition of soils also has an effect on the amount of heat absorbed. As a rule, sandy soils are warmer than clay soils.

The fineness of the soil particles has also a marked influence on its temperature. Coarse, rocky soils suffer from extremes of temperature. In fine, well-cultivated soils the temperature is almost uniform.

\section{Questions}

1. Soils that have been moved from their place of formation are called what? 2. Soils that remain where they are formed are called what? 3. By what means are soils usually 
transported? 4. Name the several classes into which solls may be divided? 5. What is a sandy soll? 6. What is a loam? 7. What is a clay soll? 8 . What is meant by a light soll? 9. What is meant by a heavy soll? 10. What is meant by a warm soll? 11. Name a well known compound having a great influence on soll temperature? 12. How may the presence of water prevent a soll from becoming too warm?

\section{PROBLEMS}

1. If a soll welghs 78 pounds to the cublc foot, how many pounds in an acre of such soll one foot deep?

2. If a soll welghs 90 pounds to the cublc foot ard contains 75 per cent of sand, what is the weight of the sand in one acre of such soll one loot deep? 


\section{CHAPTER XV.-CoMposition of SOILS}

78. Water.-All fertile soils contain water, though the amount varies greatly under varying conditions. The desert soil contains no water; the soil of the swamp contains an excess of water; and between these two extremes are the great areas of cultivated soils. Water is a necessary part of all fertile soils.

79. Organic Matter.-Besides water there are two kinds of matter making up soils-organic and inorganic. If a sample of soil be gently heated in an oven it loses in weight, and the loss is due to the evaporation of moisture. If the sample be burned at a dull, red heat it loses more in weight and changes color; this loss is due to the burning of organic matter, which passes off as gas and smoke just as it does when a plant is burned. See page 46 .

The organic matter of soils results from the decay of plants and animals. In cultivated fields the organic matter comes mainly from the stubble of harvested crops, the decay of dead weeds, and from the addition of stable manure. In wood land it results from the decay of dead leaves and the fallen branches and trunks of trees. As the organic matter of plants is made up of $\mathrm{C}, \mathrm{H}, \mathrm{O}, \mathrm{N}, \mathrm{S}$, so :he organic matter in the soil must be made up of the same elements; and as organic matter decays these elements form compounds which serve in time to build up other plants. Thus the organic 
mațter of plants may be used over and over again for plant food.

The decay or rotting of organic matter in soils is due to the action of bacteria which inhabit the soil. 'These bacteria feed on the organic matter and eause decay. They are sensitive to heat and cold. and require a constant supply of fresh air and water. That these statements are true is shown by the rollowing well-known facts: Dead organic matter does not decay when irozen; thus frozen meat or vegetables may be kept for years and show no sign of decay. Dead organic matter may be dried and kept for a long time, but when moistened it decays. Dried or smoked meat is a good example of this. If sealed up from the air, organic matter keeps indefinitely. Canned goods are an example of this fact. The conditions under which the bacteria of decay act best are the same as those necessary for the sprouting of seed. They require heat, moisture, and air, and, as in the case of the seed, it is the oxygen of the air that is used.

- As we have already learned, the decay of the dead organic matter of the soil results in the formation of a substance called huinus. Humus is a dark, almost black, product, which gives to garden soil its rich, dark color. It is a mixture of many different compounds, all of which are made up of the four elements-carbon, hydrogen, oxygen, and nitrogen. Humus iz of great importance in the soil, and we shall have more to say of it later on.

80. Inorganic Matter.-The mineral matter which makes up more than $) 0$ per cent of most soils is a mix- 
ture of many different compounds. But there are two compounds which are common to all soils and which serve as a basis for their classification. These two compounds are sand and clay.

81. Sand.-The element silicon, when combined with oxvgen, forms a hard compound, which we know as quartz rock. Quartz often forms small crystals, and in this form makes up a large part of many kinds of rocks, such as granite, sandstone, and some forms of limestone. When these rocks decay, the quartz particles being very hard and insoluble, remain behind and form what is known as SAND. Besides quartz grains, sand contains fragments of other minerals, such as mica, particles of iron, and lime. Sand is seldom, if ever, made up exclusively of quartz. Silica, as quartz is called, makes up more than one-half of the dry land. It is found in many rocks, and makes up a large part of most soils. It is one of the most abundant substances on earth. Silica is almost insoluble in water; the sand of river and creek beds being practically unaffected by the running water. Water runs through sand easily, and after being wet the sand dries out quite rapidly. Sand has no tendency to become sticky, and though wet sand may stick to one's clothes or person, it is easily brushed off. Sand absorbs much of the sun's heat, as any one who has walked through warm sand with his bare feet can testify. Sand alone makes a poor soil for growing plants; besides supplying little food itself, it holds little or no moisture and becomes very hot when exposed to the sun.

82. Clay.-This substance in its properties is very different from sand, though it is what chemists call a 
silicate; that is, it contains the two elements which make sand, combined with another called aluminum. Aluminum is a light metal, much like silver in appearance, and much used for manufacturing small articles, such as combs, penholders, etc. The metal aluminum is made from clay. Aluminum, silicon, and oxygen make CLAY.

Clay is a very soft substance, smooth and almost greasy to the touch. When dry it may be easily pulverized, falling into a powder as fine as the finest flour. Pure clay, such as the fine grades of kaolin, has no sand or grit in it, and may be easily cut with a knife. When wet it becomes sticky like dough or putty, and may be moulded into any desired shape. Kaolin or pure clay is used to manufacture pottery and chinaware.

In the soil, clay exists as a fine powder, and it is the clay particles that make soil sticky. Clay when once wet dries out slowly, hence clay soils retain water. $\Lambda \mathrm{s}$ clay soils retain much water, which evaporates slowly, they are, as a rule, cooler than sandy soils. Clay and sand have almost opposite effects in a soil. Clay in soils holds water, making the soil cool and moist. It is sticky, and serves to bind the particles of soil together. Sand, on the other hand, holds little moisture, and its presence tends to make the soil warm and dry. Its particles are not sticky; hence sandy soils are loose and easy to work.

\section{FXPERTMENT}

Thike some clan sand, wet it and mould it into any desired shape. Notice hous soon is dries out and crumbles to pieces. Pour vouter on 6 
dry sand and notice how quickly it runs through, and how soon the surface of the sand dries out. Treat some ordinary clay in the same way and notice how differently it behaves. Mix the sand and clay in varying proportions and find the proportions of each required to furnish a mixture resembling the soils in your neighborhood.

\section{Questions}

1. Of what two kinds of matter besides water are solis made up? 2. The organic matter in soils comes from what two sources? 3. What elements make up the organic matter of soils? 4. What causes the decay of organic matter in soils, and what substance is produced by this decay? 5. Why is it that frozen meat or vegetables keep so well? 6. Why is it that smoked or dried meats keep? 7. Why is it that canned meats keep? 8. From what source is the mineral matter of soils derived? 9. Name the three principal constituents of soil. 10. Of what two elements is sand made up? 11. What are large rocks made up of these two elements called? 12. How is sand formed? 13. How does clay behave when wet? 14. How would figures moulded of wet sand behave when dry? 


\section{CHAPTER XVI.-CoMposition of SoILS}

(CoNTINUED)

83. Plant Food in Soils.-In the last chapter we considered four substances-water, organic matter, sand, and clay, which make up so large a part of all soils. But while these substances make up a large part of all soils, they furnish the plant with but a small part of its mineral matter. Water and organic matter are both indispensable as plant foods, but sand is of almost no value, and pure clay is little better than sand. Sand and clay are not of much use as plant foods, but they serve as a sort of storehouse for the plant supply of food and water, and they also make up the soil in which the plant roots grow and develop. The clay particles in the soil hold water from which the plant may draw its supply. They also hold certain valuable plant foods which they give up to growing plants. Sand prevents the soil from becoming too wet and sticky, and also absorbs much heat from the sun. Mixed in with the sand, clay, and organic matter are small quantities of various mineral compounds that make up the ashes of plants. Four mineral elements are absolutely necessary to the growth of plants; they are phosphorus, potassium, calcium, and iron. Many others are found in the ash of plants, but they do not seem to be as necessary as the four mentioned.

84. Phosphorus in Soils.-This element in some form 
of combination is found in all soils, and comes from the decay of rocks which contain phosphorus compounds. It is in some instances found combined with lime, in which form it is called BONE PHOSPHATE, making up, as it does, a large part of the bones of all animals. Often it is found combined with iron and aluminum, when it is called IRON AND ALUMINUM PHOSPHATE. Most soils contain comparatively small quantities of phosphates, .1 per cent. being a fair supply; some rich soils may contain as much as .5 per cent, but this is unusual. Poor soils contain not more than .05 per cent. Besides the phosphates mixed with the finer soil particles, many of the coarse fragments in the soil centain a small quantity of phosphates, which, as the fragments decay, is added to the fine soil.

85. Potassium in Soils.-Compounds of this element are found in all soils, and come from the decay of rocks containing potash. The rocks which supply most of the potash of soils are called FELDSPARs, and are found all over the earth. The potash in the soil is usually combined with silica to form compounds known as POTASSIUM SILICATES.

Clay comes largely from the decay of the same rocks that supply potash to the soil, and as clay is also a silicate it is often united with potash to form DOUBLE silicates. The amount of potash in different soils, of course, varies greatly; in some soils it reaches as high as 2 per cent; in poor soils it often falls below .1 per cent.

86. Calcium in Soils.-Compounds of this element make up a small part of all fertile soils, and are the 
result of the decay of rocks containing some form of calcium. The compounds of calcium found in soils are popularly called Limf. In regions where limestone rocks are abundant the soil is well supplied with lime; but where the soil has been formed by the decay of such rocks as sandstone but little lime will be found. The amount of lime in the soils is, of course, dependent on the amount of lime in the rocks from which they are formed, and for this reason the supply of lime in various soils is very different. As already mentioned, the soils of limestone regions are well supplied, and are, as a rule, very fertile. The soils of the famous bluegrass regions of Virginia, Tennessee, and Kentucky are formed from limestone rocks, and are noted for their fertility. Besides forming plant food, lime has a decided influence on the supply of nitrogen in the soils and also on their mechanical condition.

The quantity of lime in soils varies greatly; in some rich limestone soils it. may reach 2 to 3 per cent, and in poor, sandy soils fall as low as .1 per cent. The calcium in soils is usually combined with carbon and oxygen to form a carbonate, or with phosphorus and oxygen to form phosphates. Sometimes it is combined with sulphur and oxygen to form a sulphate.

87. Iron in Soils.-This element occurs abundantly in all soils, however poor. It is usually found combined with oxygen, forming an oxide, or with oxygen and water to form a hydrate; at times it is combined with phosphorus and aluminum. Nearly all rocks contain iron, which becomes a part of the soil when the rocks decay. Iron gives to soils their various colors 
of red or yellow. The amount of iron in most cultivated soils seldom falls below 1 per cent.

88. Other Elements in Soils.-Sodium, magnesium, chlorine, aluminum, and a number of other elements besides those already mentioned are found in soils; but they are of little importance as plant foods, so need only be mentioned.

89. Analyses of Soils.-To analyze a soil means to determine the various elements and compounds it contains. The following figures show the comparative composition of samples of rich and poor soils. These figures are from actual analyses, the rich loam being a sample of soil from a rich bluegrass region, and the poor sand a soil from a very poor region of country:

Rich Loam.

Limestone Soil.

Organic matter......... 5 per cent.

Sand ............ 75 per cent.

Clay .............. 20 per cent.

With the sand and clay:

Potash ........... 0.5 per cent.

Phosphoric acid...... 0.2 per cent.

Lime ............ 0.5 per cent.

Iron $\ldots \ldots \ldots \ldots \ldots \ldots 2$. per cent.
Poor Sand. Sandstone Soil. 2 per cent. 90 per cent. 8 per cent.

\section{Questions}

1. How do sand and clay aid the growth of plants? 2. Name four mineral elements nernssary to plant growth. 3. From what does the phosphorus in soil come? 4. With what other compounds is it usually combined? 5. Give some idea of the amount of phosphoric acid found in soils. 6. From what rocks does the soil's supply of potash come? 7. With what substance is the potash of soils usually combined? 8. What rocks form soils rich in lime? 9. Why do 
sandstono solls contain little lime? 10. What is a general characteristic of limestone solls? 11. With what element is the calcium in solls usually combined?

\section{PROBLEMS}

1. A sandy soll weighs 110 pounds to the cubic foot, and contains 0.04 per cent of lime. Calculate the total weight of lime in an acre of such soll one foot deep.

2. A rich loamy soil welghs 90 pounds to the cubic foot and contains 0.60 per cent of lime. Calculate the weight of lime in an acre of such soll one foot deep. 


\section{CHAPTER XVII.-WATER IN SOILS.}

90. Importance of Water in Soils.-Water and nitrogen have both been mentioned as making up a part of all fertile soils, but so far we have devoted little space to them. These two plant foods are of so much importance that they each require a separate chapter for their consideration, and we shall begin with water. In order that any soil may grow plants a supply of water is absolutely necessary; therefore it is of the first importance.

91. Film Moisture.-Soils are made up of a great number of particles of various shapes and sizes piled loosely together. A pile of broken rocks or stones may serve to illustrate on a large scale how soils are made up. The spaces between the soil particles are filled with air or water, as the case may be. In dry soils most of the spaces are filled with air; but when the soil becomes wet the air is driven out, and they become filled with water, and at the same time each soil particle becomes surrounded with a film of water. Dip a marble in water and notice how it comes out wet all over; it is surrounded by a layer or film of water. When soil becomes thoroughly wet each soil particle is surrounded by a film of moisture, like the wet marble. The water fllling the air spaces soon sinks deep into the soil and part of it drains off, leaving in the upper soil only the moisture surrounding each particle of soil, or what 
is called the FILM Moisture. This does not drain off and serves to keep the soil moist, supplying water for growing plants. The amount of water held as film moisture varies greatly in different soils.

Pour water over a pile of broken stones or coarse gravel. Each stone soon becomes surrounded by a film of water; then the pile will hold no more water, and if more is added it simply runs off. Exposed to the air or sun, the pile of stones soon dries out, and the moisture disappears, leaving the stones as dry as before they were wet. Now, pour water on a lump or two of dry clay, of about the same weight as the stones, and notice how much more water it absorbs than the stones. After the clay becomes thoroughly wet, it may be exposed to the air and sun a long time before it dries out. The elay consists of a great number of small particles, each of which, when wet, becomes covered with water; most of the air spaces between the particles are also filled, and in this way much water is taken up. As only the outer particles are exposed to the air and sun the lumy dries out slowly. The pile of stones, on the other hand, consists of a small number of coarse particles, and consequently holds less film moisture. The water quickly drains from the air spaces, leaving each particle exposed to the air, which quickly evaporates the film moisture.

The Cornell Fxperiment Station has published two interesting drawings illustrating the anount of water held by different soils. This experiment was made by the Station Chemist, and is described as follows:

"He put small marbles in a tumbler, as shown by 
Fig. 12, and the total amount of film moisture that the marbles would carry is represented in the tube placed ii beside the tumbler. The soil in the other tumbler (Fig. 13) is of the same weight as the marbles in Fig. 12, and it represents the marbles reduced to the fineness of common sand. Its capacity for holding film moisture is represented by the water in the standing tube (Fig. 1乏). The weight of material is the same in each tumbler, and the reason why one holds three times more film moisture than the other is due to the increase of surface that comes by dividing a coarse lump into fine particles."*

This experiment seems to prove conclusively that the power of a soil to hold water depends in a large measure upon the fine-

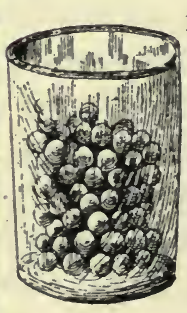
ness of its particles.

92. Free Water.When rain falls on the surface of the earth, part of it sinks into the soil unti! it reaches some hard layer of

Fil m mig. 12 -Fil m marbles. (From Bullelin No. 174, Cornell Experiment Station.) earth or rock, through which it cannot pass. The water that has drained down from

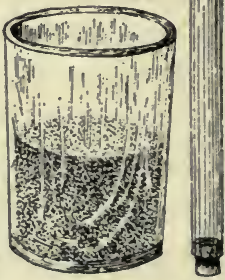

FIG. 13.-Film moisture held by marbles when reduced to powder. (From Bulletin No. 174 Cornell Experiment Station.)

the soil above rests on this layer, and follows it until it comes out as a spring or well. Fig. 14 shows how

*Cornell Experiment Station Bulletin, No. 174. 
springs and wells are formed. 'The water that follows this impervious layer is called FREE or GROUND WATER, to distinguish it from, the film moisture surrounding each soil particle. It must not be supposed that the ground water flows in a regular stream along this impervious stratum, for it does not. It fills all the spaces in the soil lying directly above the stratum, and drains gradually towards the spring (Fig. 14). We have, then, as shown in the figure, first, a layer of soil containing only film moisture, then a layer of wet soil, containing free or ground water, and, finally, the

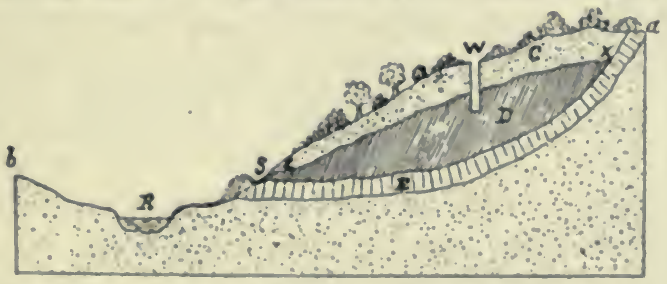

F16.11. - Water table in soll. a b. surface of ground: $C$, soll eontalning film molsture; $D$, soll contalning free water; $F_{1}$ Impervlous stratum; s, spring; $K$, stream; $W$. well. $x z$, IIne of water table.

impervious layer. The digging of a well proves the truth of these statements; the well first passes through a comparatively dry soil which carries only film moisture. Finally, the well reaches a layer of soil which is wet, and as it sinks into this layer it fills with water to the point where the wet soil begins. If carried deep enough, below this wet soil will be found a layer of hard clay or stone. There is usually a well marked line where the soil containing. film moisture ends and the free water begins; the line $x y z$ in Fig. 14 shows where the change occurs, and it is called the WATER 
TABLE. The water table is the beginning of the free water in the soil. Below the water table the soil is like a great sponge filled with water, and it is from this supply of free water that the soil above draws its supply . in dry weather. The bottom of wells must always go below the water table. As film moisture evaporates from the surface soil, more rises from the free water below to take its place. Dip the end of a dry towel in water, and notice how the water rises through the towel towards the dry end; a dry sponge sucks up water in the same way and illustrates perfectly how film water rises towards the surface of the soil. Part of the free water drains from the soil at some spring or well, and the remainder rises to supply the film moisture in the soil above. The supply of water in soils is renewed from time to time by rain, and as more rain falls the water table rises; in very wet weather it may reach the surface of the ground, and when such is the case. the soil is completely saturated with water. In dry weather as the water drains from the soil, the water table sinks lower and lower, till finally it sinks so low that almost no film moisture reaches the soil above. Then a drought is at hand, and plants growing in the soil suffer for water.

93. Deep and Shallow Soils.-When the impervious stratum is near the surface of the soil the water table is also near the surface, and consequently in rainy weather the soil becomes very wet; on the other hand, in dry weather the small quantity of film moisture in the soil evaporates quickly, and leaves the soil very dry. Such soils are said to be shallow. When the imper- 
vous stratum is far below the surface the soil is said to be deep.

Water, then, is found in the soil in two forms; in the soil near the surface it ordinarily exists as film moisture. In the lower soil it is found as free water, which, rising in the soil, forms the film moisture above.

\section{EXPERIMENT}

To illustrate how free ualer rises in soil and becomes film moisture, the following simple experiment is useful:

Take an ordinary glass tube of any convenient size and stop up one end with a plug of loosely filting cotton. Then fill the tube with dry soil. Dip the end with the colton plug in water just decp enough to cover the end of the tube. Water rises through the dry soil until it is all thoroughly moistened. Fig. 15 illustrales this experiment.

\section{Questions}

1. When a marble is dipped into water what happens to it? 2. When water is poured on a pile of stones with what does each stone become surrounded? 3. When rain water soaks into the soll with what is each little soll particle

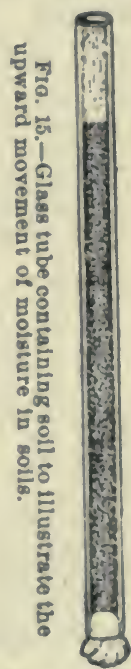
surrounded? 4. What is the moisture surrounding each soll particle called? 5. Which absorbs the more moisture, a plle of fine earth or a plle of stones, and which dries out the more rapldiy? 6. When water which soaks through the soll reaches a hard layer of soll or rock through which it cannot pass what happens to It? 7. What is the water that flls the soll just above the impervlous stratum ealled? 8. The dividing line between the soll flled with iree water and that containing film molsture is called what? 9. Why does the level of a water table change? 10. How deep does a well have to go in the soll belore it reaches water? 11. How does the free water supply $\mathrm{flm}$ moisture to the soll above? 12. In wet weather how does the water table bebave? 


\section{CHAPTER XVIII.-NitrogEN IN SoILS}

94. Importance of Nitrogen in Soils.-We have already mentioned the fact that nitrogen is one of the most important of all plant foods. It is important because no plant can grow without a supply of this element, and, furthermore, because the supply in the soil is easily exhausted through careless cultivation, and, when once exhausted, is with difficulty replaced. It seems strange that plants should ever want for nitrogen when they are surrounded by air which is fourfifths nitrogen. But there are only a few kinds of plants that can make any use of the nitrogen of the air, and even for them the nitrogen must first enter the soil and there be changed into the proper compounds. All of the plant's nitrogen supply is taken in through its roots.

95. Sources of the Soil's Supply of Nitrogen.-The soil's supply of nitrogen comes from three sources. First, and most important, is the nitrogen combined in the organic matter in the soil; second, the nitrogen contained in the air which fills many of the spaces between the soil particles; third, the compounds of nitrogen, ammonia and nitrates, which are washed from the air by rain water. The amount of nitrogen brought to the soil by rain water is insignificant compared with the amount supplied by organic matter. The nitrogen held by the air in the soil is useful to only certain kinds of plants, and by far the most im- 
portant compounds of nitrogen are those contained in the organic matter.

96. Nitrification.-All the nitrogen compounds of plants are, as stated before, called by one nameprotein. When plants decay in the soil the protein compounds are destroyed by the bacteria which feed on the organic matter. Most of the nitrogen of the protein compounds is finally changed by the processes of decay into other compounds of nitrogen, which are known as nitrates, and this change is called NITRIFIcation.

All of the changes which the protein compounds undergo in being converted into nitrates are caused by bacteria, which work only under certain conditions. These conditions have already been stated on page 78 , and they show that in temperate regions of the earth nitrification can only take place during the summer months. This is fortunate, for the nitrogen compounds formed by this process are very easily dissolved in water, and if not taken up by growing plants would be quickly washed from the soil by rain water and so lost. Nitrification can only take place in moist soils well supplied with air, and is most active when the temperature is between $95^{\circ}$ and $100^{\circ} \mathrm{F}$. Nitrification ceases when the temperature rises above $130^{\circ} \mathrm{F}$. or falls below $53^{\circ} \mathrm{F}$. The nitrates are easily dissolved in water, and in this condition pass into the roots of plants and are finally built up by the growing plant into fresh protein compounds. By this process of nitrification the same nitrogen is used over and over again. But, of course, there is always some loss of 
nitrogen. During the process of decay some of the nitrogen escapes into the air in the form of ammonia; the smell of ammonia may often be noticed rising from decaying organic matter. Then some of the nitrates are washed from the soil by rain water. In some way this loss must be made good, else the store of nitrogen in time becomes exhausted. The nitrogen compounds washed from the air are not in sufficient quantity to make good this loss, the minerals in the soil can supply no nitrogen, and the only remaining source is the free nitrogen of the air.

It is only within the last few years that we have learned that some plants make use of the nitrogen of the air for food. Beans, peas, clover and other plants of the botanical family which is known as the LEGUMINOSA or PULSE FAMILY, all contain notably large quantities of protein. Yet these crops often grow and flourish on soils which will not produce crops of wheat, corn, or oats until some nitrogeneous fertilizer is added. That the plants of the leguminous family could draw on some supply of nitrogen which was not available to other crops has been a recognized fact for many years. But how or where they got their nitrogen was not known until recently. Now, we know that leguminous plants obtain parts of their nitrogen from the air, and that it is supplied to them by bacteria. On the roots of clover, beans, peas, and other plants of this family are found, ordinarily, small enlargements or knots which are called TUBERCI.ES. These tubercles are the homes of the bacteria which make the nitrogen compounds from the nitrogen of 
the air. 'They fix themselves on the roots, and cause the tubereles to grow. This has been proven by growing clover or beans in soil known to be free from all bacteria. When this was done no tubercles were formed on the roots, and the plants made a very poor growth. Fig. 16 shows the tubercles formed on the roots of a soy or soja bean plant, which belongs to the pulse family. The bacteria which inhabit the roots of

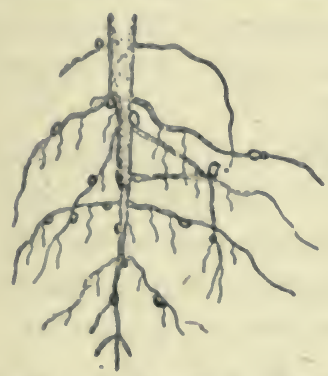

F10. 16.-Roots of yelluw soy bean, grown at the Kan. eas Agricultural kxperiment station in 1860, on land inoculated with an extract contalning the tubercle-forming hacterla. (From Yearbook. U. S. Dept. Agr., 1997.)

leguminous plants have the power of ehanging the free nitrogen of the air into the compounds of nitrogen known as nitrates-and these compounds are readily taken up by the plant roots. In this way, as it were, the bacteria pay rent to the plant for their homes on its roots. Why it is that these nitrifying bacteria live only on the roots of one family of plants is not known, but they evidently prefer these plants, for so far as we know at present they do not inhapit the roots of any other family. The family of leguminous plants is a large one, and some of these plants are found in all soils and climates. In this way nature renews the store of nitrogen in the soil, but in cultivated fields the conditions are very different.

Many soils do not contain any of the bacteria which change the nitrogen of the air into nitrates. In such soils no tubercles form on the roots of legumes, which 
plants are in consequence forced to draw their supplies of nitrogen from the soil, like wheat, oats, or any crop having no power to use the nitrogen of the air. Without the proper kind of bacteria legumes are unable to make any use of the nitrogen of the air. To supply deficient soils, these bacteria are now prepared for sale, and they may also be supplied by adding to the deficient soils quantities of another soil known to contain them. It is probable that in a few years the various nitrifying bacteria will be sold in the market much as fertilizers are sold to-day.

97. Forms of Nitrogen in Soils.-We have learned the sources from which the soil is supplied with nitrogen; now, how are these compounds held in the soil? A part of the nitrogen is held in the undecayed organic matter, some is combined in the humus, and the air in the soil contains free nitrogen. In all of these forms the nitrogen is unavailable to plants for food, and must first be converted into nitrates by the bacteria before it may be used. The soil contains some nitrates, as does the soil water, but these compounds are in small quantities because they are so easily washed from the soil.

\section{Questions}

1. Why is nitrogen particularly important as a plant food? 2. From what three sources is the soil's supply of nitrogen derived? 3 . What happens to the protein compounds when the plant decays in the soil? ${ }^{\circ} 4$. What causes the decay of plants in the soil? 5. What nitrogen compounds are formed when plants decay in the soil? 6. What is the process of the formation of nitrates called? 7. When is nitrification most active? 8. When plants decay is there 
ever any loss of nitrogen? 9. Name a family of plants contalning large amounts of protein. 10. Have leguminous plants the power of obtaining nitrogen from any other source than the soll? 11. How do leguminous plants obtaln nitrogen from the air? 


\section{CHAPTER XIX.-How SoILs Lose WateR}

98. How Soils Become Poor.-The fact that cultivated soils lose their fertility, becoming poor and producing small crops, is only too well known. But how this loss of fertility occurs is not so well known, and the answer is not easy to find.

Growing plants are very particular about their food. They require a number of different compounds, which must be supplied them in certain combinations, else the plant will have none of them. If the soil should fail to supply the plant with only-one of the many foods it requires, the plant starves, or if the food be supplied in a form not acceptable to the plant, it will not take it. For instance, a soil that contains no nitrogen, even though it contains every other plant food, cannot grow crops. A soil that contains only nitrogen combined in organic matter and provided with no means of forming nitrates will be as barren as a desert. Fertile soils are soils that supply all kinds of plant foods and supply them in the form most acceptable to plants. When the supply of any one or more of the foods becomes, from any cause, exhausted, the soil is called poor or worn, which means that it cannot feed growing plants. The supply of plant food in most soils is rarely excessive, and is often small. It is an easy matter to exhaust, by improper methods 
of cultiration, one or more of the different foods, but to renew the supply is not so easy. The two plant foods most easily exhausted and most difficult to replace are water and nitrogen, and as they are to a certain extent dependent on each other, a soil lacking in one is apt to be lacking in both.

99. Moisture Often Lacking in Soils.-The plant food most often lacking in soils is moisture. The great areas of land known as deserts are deserts because they have no supply of water. The oases of deserts owe their existence to a supply of water from some spring or well. Provide a desert with a supply of water, and it ceases to be a desert, and in time may become fertile. In many parts of our country are great stretches of land, which, while not reduced to the condition of a desert, are so poor that the crops produced are hardly worth the gathering. These lands were once clothed with a dense growth of magnificent forest trees; now they produce for those who cultivete them the most meagre crops. What has eaused the change? Has the mineral food of the soil become exhausted? Has the nitrogen supply been used up, or has the water supply failed? If left uncultivated these lands grow up again in trees, and as time passes they become elothed again in great forests. Fvidently there is enongh plant food aceumulated to produce great crops of trees: then why not enough for farm crops? There is an ample store of mineral plant food in these poor soils, but two things are lacking - water and organic matter. But if they are lacking how ean great crops of trees grow up? Growing trees add to the soil's 
supply of both water and organic matter, and so increase its fertility. How they do this is explained in succeeding paragraphs.

100. How the Water Supply of Soils is Renewed.The supply of water in soils is renewed from tine to time by rains, much of the rain water being held in the deep soil as free or ground water. From the deep - soil it rises into the surface soil as film moisture which provides growing plants with a constant supply. The more free water a soil holds the greater the store for growing plants. If for any reason the free water of a soil becomes exhausted the plants growing in the soil wilt and die. Growing plants require a constant supply of water, which they can obtain. only from the film moisture of the soil. Rains are often weeks apart, and unless water is held by the soil plants suffer. The soil below the water table may be considered as a reservoir which holds rain water, much as a sponge, and supplies it as needed to growing plants. If there be a leak in the reservoir the water supply is lost. The depth of the soil and the number and size of the soil particles in a measure determine the amount of film moisture a soil is capable of holding. But in order that a soil may contain film moisture water must be first absorbed and held below as free water. If rain water runs off the surface, the soil can contain but little moisture. In bare fields this is often the case; the rain water runs off the surface, cutting great gullies and doing much damage to the land. On land covered with growing plants or the litter of dead plants, rain water is prevented from running off, and gradually 
soaks into the soil, where much of it is held as film moisture. To use a homely illustration, let us suppose water is poured on the head of a perfectly bald person; it quickly runs off from his head, falling on his face and person, leaving the head scarcely wet. If, on the other hand, water is poured on the head of a person with a heavy suit of hair, but little runs off till the hair is thoroughly wet. This, in a way, illustrates how growing plants protect lapd from washing, and cause rain water to enter the soil.

\section{How Growing Plants Stop Surface Evaporation.} Growing plants, besides protecting the soil from washing, prevent excessive surface evaporation, which carries off much moisture from exposed soils. Sunshine and winds are constantly at work eraporating great quantities of water from exposed fields, leaving the soil dry and hard. On bare fields the loss of water through surface evaporation is enormous. To illustrate how this loss takes place, let us suppose we have an ordinary bucket half filled with wate::; if left open to sunshine and wind the water in the bucket quickly evaporates; it passes through the air which fills the upper half of the bucket and disappears into the outer air as water vapor. If the bucket be covered over to protect it from the wind and sun, much of the eraporation is stopped. Now, the soil is much like a bucket half full of water. We have first a layer of comparatively dry soil, that is soil containing only film inoisture. This corresponds to the air in the upper half of the water bucket. Then we have a layer of soil filled with water, and the whole rests on a bottom formed by the imper- 
vious stratum or layer. If the soil is bare and uncovered to the sun and wind, the water from below rises through the upper layer of soil and evaporates. Cover the soil with either growing or dead plants to protect its surface, and the evaporation is stopped, as it is in the bucket. Anything used to cover the surface of the soil to prevent evaporation, or washing, is called a mulch, and the process is known as MULCHING.

It is in the winter and early spring months that most of the rains fall, and in protected soils the excess of moisture is stored up for the use of plants during the drier months of summer. If, however, the soil be left bare, the winds and sunshine of spring evaporate vast quantities, and when summer comes with its hot, dry days the growing plants find but a poor supply of water stored up for their use.

102. Condition of Cultivated Fields.-Now, what is the condition of many cultivated fields during the season of heaviest rainfall? Take the tobacco lands, for example; after a crop of tobacco is gathered the soil is left almost perfectly bare. Tobacco is gathercd so late in the season that no weeds can grow, and the only protection the soil has from the washing rains of winter is the scattered stubble from the crop itself. The cotton lands of the South fare but little better than the tobacco lands; their only protection being the dry, dead stalks scattered over the fields. Often these are collected and burned, leaving the soil with no protection for the winter. Wheat and oat lands fare much better; for after these crops are cut heavy growths of weeds spring up, and these, when plowed under, supply 
the soil with a great mass of decaying organic matter, which serves to hold much of the winter's rain, and checks surface evaporation. Cultivated soils that have any tendeney to wash or leach should never be left bare to the action of the winter rains.

\section{Questions}

1. What are fertile soils? 2. If a soll falls to supply any one of the essential plant foods what is It called? 3. How does a soil become poor? 4. Name two important plant foods often lacking in soils. 5. Why is it that deserts produce no plants? 6. How are the oases of deserts formed and how may they become fertile? 7 . If worn lands are left uncultivated for any length of time what sort of crops spring up? 8. How is the supply of water in solls renewed? 9. How is rain water. held in soils? 10 . How are plants constantly supplied with water? 11. Why do solls covered with growing plants or the litter of dead plants contain more film moisture than bare fields? 12. Give an fllustration of how plants protect solls from washing. 13. Why do lands that have been cropped in tobacco or cotton suffer from washing and leaching? 14. Which as a rule contain more film molsture, lands left bare all winter or lands covered with vegetation? 


\section{CHAPTER XX.-How SoILs Lose Nitrogen}

\section{Nitrogen Necessary to Fertile Soils.-Many} cultivated soils become worn and unfit to produce profitable crops through the loss of their supply of organic matter which contains nearly all the nitrogen. A supply of nitrogen is just as necessary for growing crops as a supply of water; and the nitrogen supply of soils is to a certain extent dependent upon the watcr supply, because the bacteria which change the protein into soluble compounds of nitrogen cannot work in perfectly dry soils. In order, then, that soils may contain nitrogen, they must contain a supply of moisture. As cultivated lands are robbed of their water supply, becoming hard and dry, they are at the same time being robbed of their nitrogen. A dry soil can supply the plant with neither water nor nitrogen, and is said to be deficient in these two plant foods.

104. Decay of Organic Matter Necessary to Form Nitrogen.-To contain a supply of nitrogen soils must, in the first place, contain some form of decaying vegetable or animal.matter; and, in the second place, in order that the organic matter may decay and other compounds of nitrogen be formed, the conditions in the soil must be favorable to the bacteria which cause the changes.

105. Loss of Nitrogen Through Cultivation.-On wooded lands the leaves of the trees die, fall to the ground and go to form humus in the soil; the trees 
themselves in their turn die, decay, and pass back into the soil; and by this process of gradual growth and decay but little nitrogen is lost. But the conditions are very different in cultivated fields. Here quantities of nitrogen-containing organic matter are each year taken from the soil, and but little returned. $\Lambda$ crop of hay, for instance, weighing about 2,000 pounds, takes from the soil about $1, \tilde{r} 00$ pounds of organic matter, which contains about twenty-five pounds of nitrogen. And so each crop taken from the soil removes a certain amount of nitrogen. Nearly all of this nitrogen comes from the decay of organic matter in the soil, and unless fresh organic matter be added to replace that used up, the supply must in time become exhausted, and the bacteria of decay be left without material from which to manufacture compounds of nitrogen. Suppose a crop removes from the soil twentyfive pounds of nitrogen; if the organic matter in the soil contains about 1 per cent of nitrogen, such a crop would require 2,500 pounds to supply its nitrogen. The roots and stubble from crops decay in the soil, and are converted into humus and some compounds of nitrogen, bit they cannot supply enough nitrogen to replace that removed by the crops. After each crop is removed the soil should be supplied with organic matter which may be converted by the basteria into fresh supplies of humus. After some crops, such as wheat and oats, crops of weeds spring up, which, when plowed under, supply fresh quantities of organic matter. But other crops, such as tobaceo and cotton, leave the soil with only a few scattered roots and stubble. When 
crops of tobacio or cotton are removed year after year from the same field and no organic matter is added, the soil's store of nitrogen soon becomes exhausted.

106. Denitrification.-But the loss of nitrogen in soils occurs not only from a decrease in the supply of organic matter. The influence of moisture on nitrogen compounds in soils has already been mentioned. Nitrification takes place only in moist soils; in very dry soils not only does nitrification cease, but there is actually a loss of nitrogen or what is called DENITRIFICATION. By a process of dry decay the nitrogen. compounds in the soil are broken up and the nitrogen passes into the air as free nitrogen gas. A loss of nitrogen also takes place from very wet soils and from soils poorly supplied with air. The water in wet soils drives out the air, and without a supply of oxygen no nitrates can be formed from the decaying organic matter. Some nitrogen compounds are also washed from the soil in the drainage water, and some escape as ammonia gas. And while the loss in this way from ordinary soils is not great, still it is enough to affect the total supply.

Is it any wonder, then, that the cotton and tobacco lands become poor, and fail to produce crops? Washed and leached by the winter rains, scorched by the sun, parched by the winds, robbed of their water and organic matter, how can they produce crops?

\section{Questions}

1. How does the loss of organic matter affect soils? 2. Name two very important plant foods. 3. How does 
the water supply of solls affect the supply of nitrogen? 4. What three things are necessary for the formation of nitrogen compounds in solls? 5. What becomes of the dead leaves of trees? 6. What effect do crops have on the supply of nitrogen in solls? 7. What is denitrification? 8. How do dry solls lose nitrogen? 9. How do wet soils lose their nitrogen? 10. Why do tobacco lands often suffer a greater loss of nitrogen than wheat lands? 11. Why do cotton lands suffer a loss of nitrogen? 


\section{CHAPTER XXI.-How SoIls Lose Mineral Matter}

\section{How Cultivation Removes Mineral Matter from} the Soil.-Soils. become impoverished from careless cultivation, which causes a loss of water and nitrogen. They may also become impoverished through the exhaustion of their supply of phosphoric acid, potash and lime. How this occurs may be understood from the fact that each crop gathered from the soil uses up for its growth and takes with it just so much phosphoric acid, potash and lime. A crop of cotton, lint and seed, weighing about 1,000 pounds, takes from the soil about $6 \frac{3}{4}$ pounds of phosphoric acid and 10 pounds of potash. One thousand pounds of tobacco leaves take from the soil about 3.4 pounds of phosphoric acid and 40 pounds of potash. One thousand pounds of hay take about 3 pounds of phosphoric acid and $12 \frac{1}{2}$ pounds of potash; and so each crop takes from the soil varying amounts of mineral plant food.

If year after year so much of these plant foods are taken away and none returned, the supply must become exhausted. As a matter of fact, the available supply does often become exhausied.

108. Phosphates in the Soil.-Phosphorus exists in the soil in several forms; combined with certain proportions of calcium and oxygen it forms a compound soluble in water, and in this form is available as plant food. Were all the phosphorus in the soil in this form, 
what the plants did not use would soon be washed out by rains and the soil left with none at all. Fortunately, most of the phosphorus in the soil is combined with iron and aluminum, in which form it is nearly insoluble in water and unavailable for plants. By some processes in the soil, probably the action of the acids in humus, the insoluble phosphates are gradually being converted into soluble compounds which become food for growing plants. This change is so gradual that just about enough soluble phosphates are made each year to supply the demand of the yearly growth ol nature's crops. Nature allows her crops to go on growing year after year, but little in the way of plant food being removed from the soil; so each year only enough plant food is required to supply the season's growth, and the supply is always abundant.

On cultivated lands a crop is usually gathered each year, and with it go from the soil the soluble phosphates it has taken up in growing. 'The next year the soii must supply more plant food for the season's crop, and so this goes on each year. The formation of solıble phosphates in many soils is so slow that there is not sufficient to supply this constant demand, and such soils are said to be deficient in phosphoric acid. Very often they have a large store of insoluble phosphates, but are unable to manufacture the soluble compounds fast enough to supply the demand of the crops. The great store of phosphates contained in most soils is shown by the following figures: An acre covers 43,560 square feet; then if the soil be twelve inches deep, we have for an acre of ground 43,560 cubic feet of surface 
soil. Now, ordinary soil weighs about 90 pounds to the cubic foot. In other words, an acre of soil twelve inches deep weighs $3,920,409$ pounds. If such a soil contains .1 per cent of phosphoric acid it would yield 3,920 pounds to the acre. Poor, sandy soil contains sometimes only 0.05 per cent phosphoric acid, or 1,960 pounds to the acre. Now, a crop of 1,000 pounds of tobacco removes 3.4 pounds of phosphoric acid. So an acre of good soil contains enough phosphoric acid to supply about 1,150 crops, of 1,000 pounds each, of tobacco, and poor sandy soil has enough for about 575 crops of the same size. These figures do not mean that the soil containing .1 per cent of phosphoric acid could be cropped in tobacco, continuously, for 1,150 years without becoming exhausted, for tobacco requires other elements besides phosphoric acid; but they do show what a great store of phosphates the soil contains which, if properly used, will furnish many crops with food. But we have considered only the first twelve inches of soil; the roots of most crops penetrate to greater depths than twelve inches; the roots of the cotton plant have been known to reach into the subsoil between seven and eight feet. The roots of wheat plants often reach a depth of four or even five feet. As the subsoil often contains nearly as much of phosphates as the soil, such crops have much larger supplies of this food to draw on than are contained in the first twelve inches. There is, of course, some phosphoric acid lost from the soil through leaching, but as most of the phosphates are very insoluble this loss in well cultivated soil is but small. An ordinary soil, if carefully cultivated, may be steadily 
cropped for many generations without exhausting its total supply of phosphoric acid, but its supply of available phosphates may be exlausted with one or two crops. The question, then, is how must the soil be treated in order that its store of phosphates may become available as food for cultivated crops. It is diflicult to answer this question satisfactorily, for the solubility of the soil phosphates is influenced by a number of different conditions in the soil, none of which is perfectly understood. But it is known that the amount of soluble phosphoric acid in soils is influenced to a great extent by the amount of humus it contains. The so-called insoluble phosphates, though almost insoluble in water, are acted on by even weak acids, and by them converted into compounds soluble in water. Humus contains a number of weak acids, and they undoubtedly act on the insoluble phosphates in the soil, converting them into forms suitable for plant food. Here we have another illustration of the value of soil bacteria, and the importance of enreful cultivation. Soil bacteria supply nitrogen for growing crops; they also have much to do with supplying the available phosphates. Some salts in the soil probably affect the supply of soluble phosphates, but their action is not so important as the aetion of humus.

109. Potash in the Soil.-The supply of potash in the soil comes, as we have already learned, principally from the decay of rocks ealled feldspars, in which the potash is combined with silica to form what are called potassium silicates. When these rocks decay and form soils, some of the silicates combine with clay and form 
what are called double silicates, which are much less soluble in water than the ordinary silicates. In this form they are preserved in the soil, and are said to be fixed. A good clay loam contains about .5 per cent of potash and sandy soils about .1 per cent. This would give for the clay soil 19,602 pounds of potash per acre of surface soil, and for the sandy soil 3,920 pounds of potash. Such a clay soil could furnish enough potash for nearly 500 crops of tobacco of 1,000 pounds per acre, or 390 crops of hay of two tons per acre. The sandy soil could supply potash for about 100 such crops of tobacco and nearly eighty such crops of hay. But this store of potash is not all available for crops; a large part of it is locked up just as the phosphates are, and the soil parts with it very slowly. These unavailable compounds of potash become available for plants in much the same way as the phosphates, that is, by the action of the weak acids of humus. These acids form compounds with the potash which are called HUMATES, and which are readily taken up by plants. Here again, through manufacture of humus, the soil bacteria are of great importance.

110. Lime in the Soil.-Sóme soils may be deficient in their supply of lime, which is an essential plant food. Besides being an essential plant food, lime is of great value in soils because of its action upon humus. Humus, as you have already been told, contains a number of weak acids which act on the phosphates and potash compounds in the soil. These humus acids also combine with the lime in the soil, and by their action on the lime, the phosphates and the potash com- 
pounds, the acid properties of humus are destroyed. If a soil contains no lime the small quantities of phosphates or potash compounds usually present are not sufficient to combine with all the acids of humus, which in consequence go on accumulating until the soil becomes decidedly acid. Now, an excess of these humus acids are harmful to the roots of growing plants, retarding their growth. Not only are they injurious to growing plants, but they are harmful to the bacteria that form humus. An animal compelled to live in an accumulation of its own manure suffers in health. So these bacteria of decay, if compelled to live in an excess of the acids which they form, suffer and cease to work. Lime acts as a cleansing agent for the bacteria of decay, by absorbing and destroying the waste products they produce in the form of acids. A noticeable defieiency of lime in soils is shown by an accumulation of acids.

111. Life in the Soil.-Most persons look on the soil as simply a mass of dead mineral matter and decaying parts of plants and animals. But the soil is far from being a dead mass. It is the home of countless millions of busy workers, bacteria, earth worms and insect forms of many kinds. It is a great workshop in which the chief workers are the little soil bacteria. It is their business to destroy the dead organic matter, manufacturing therefrom valuable compounds of humus and nitrogen, and producing acids which change insoluble compounds of phosphorus and potash into plant food; in short, to keep the soil alive. The materials with which the bacterin work are dend organic matter, water, 
air and heat; and from these they supply the world with food. Like all good workers they demand a good supply of material, and a comfortable shop well supplied with fresh air and water. A soil without bacteria is as dead as a desert, and incapable of producing plants.

\section{Questions}

1. How does the loss of mineral matter affect the fertility of soil? 2. Name three mineral elements which sometimes become exhausted. 3. About how much phosphoric acid is removed from the soil by 500 pounds of ordinary hay? 4. How are the unavailable phosphates changed into plant food? 5. Why is it an easy matter to exhaust the supply of available phosphates in ordinary soil? 6 . Why is it that available phosphates are not held in the soil? 7. Explain why the supply of phosphates in the soil is not exhausted. 8. Why do cultivated crops take from the soil more plant food than crops growing naturally? 9. How far do the roots of most plants penetrate the soil? 10. How does potash in the soil become available to plants? 11. What changes the unavailable potash into available compounds? 12. How is lime useful to the bacteria in the soil?

\section{PROBLEMS}

1. If a soil weighs 100 pounds to the cubic foot and contains 0.15 per cent of phosphoric acid, how many, pounds of phosphoric acid are contained in an acre of such soil 12 inches deep?

2. Calculate the-amount of potash in an acre of soil 12 inches deep when it weighs 95 pounds per cubic foot and contains 0.3 per cent potash? 


\section{CHAPTER XXII.CULtivation of SoILS}

112. Why Soils are Cultivated.-All fertile soils produce naturally an abundant growth of plants. This growth comes from the seed or roots of the many plants which grow naturally in the soil. The seed of such plants are scattered over the surface of the soil by various means. Many rot, many are eaten by birds and animals, and only a few of the total number ever grow; but the supply of seed is so great that even after allowing for all that are destroyed there are enough left to produce many plants. Man grows for his use crops of many kinds of plants, most of which come from seed. If the seed of these crops useful to man are merely scattered over the surface of uncultivated soil, many of them grow, but most of them are destroyed, and such methods of crop growing are seldom profitable. It has been found much better to bury the seed below the surface of the ground. where they are better protected from the agents which destroy them. In order to plant seed successfully the surface of the ground must be prepared to receive them, and the more thorough the preparation the greater the number of seed that grow and the better the plants they produce. The various methods of preparing soils for seed planting are known as culTIVATION. Not only are soils cultivated to prepare them for seed planting, but they are often cultivated to aid growing crops in obtaining their food. 
We usually think of cultivation as meaning the process of pulverizing the soil's surface by plowing, spading, rolling, etc., and these are the ordinary methods employed. But there are other methods of cultivation besides mere surface cultivation, and two that are oftentimes of great importance are DRAINAGE and IRRIGATION. They both affect the water supply of soils, and water is probably the most important of all plant foods.

113. Drainage.-In Chapter XIX you were told how soils lose their water supply, becoming dry and barren; on the other hand, there are soils that contain too much water. In many places the impervious stratum lies near the surface of the soil, and the soil being shallow, becomes quickly. filled with free water. If now the impervious stratum has little slope the free water drains away very slowly, and the only way the soil is freed from it is through surface evaporation, which, if the soil be covered with vegetation, is slow. The drainage of the soil being poor and the surface evaporation small, water accumulates and keeps the soil constantly wet. It is in this way that swamps and marshes are formed. The excessive amount of water may be drained from such soils by digging ditches through which the water may flow into some creek or river. As open ditches interfere with surface cultivation, they are usually made into what are called underdrains. In the bottom of the ditch a little culvert is built of stone, brick or wood, the joints being left open. The ditch is then filled in with earth, and the underdrain is completed. The free water in the soil enters 
the drains through the eracks and joints, which are properly-left open. Underdrains are often called blind-drains. In place of a built-up ḋrain coarsc tiles are often used. Tiles are short pieces of clay pipe, which are loosely fitted together in the bottom of the drain. Such drains are called tile-drains, and, as in the ordinary drain, the water enters through the joints.

Fig. $1 \%$ shows an ordi-

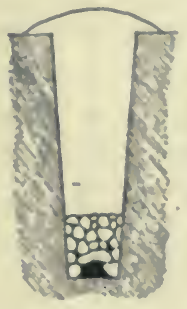

F10. 17.-Stonedraln.

nary blind-drain and Fig. 18 a tile-drain.

Besides removing thl: excess of water and renlering the soil fit for surface cultivation, drainage is of benefit to the soil in several Fig. 18.-Tile. ways. It makes the soil

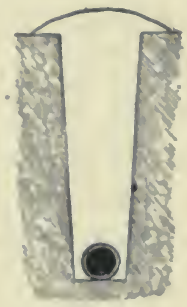
drain.

warmer by preventing the excessire surface evaporation. It allows the roots of plants to penetrate the soil to greater depths; for the roots of most cultivated crops cannot grow in a soil saturated with water. It opens up the soil to the air which supplies the roots of growing plants with oxygen, and sometimes with nitrogen.

In many parts of our country are great areas of swampy lands which, when properly drained, may become fertile farming lands. By establishing a thorough drainage system the small country of Holland has added to its territorv over 12,000 square miles of rich farming land that was once an uninhabitable swamp.

114. Irrigation.-Irrigation is the reverse of drainage, as, it is the addition, by artificial means, of 
water to dry soils. The water is usually added to the soil by means of open ditches. One main channel may supply a number of smaller ditches intersecting the field to be irrigated, and which need be only a few inches deep-little more than an ordinary furrow. These irrigation ditches are filled with water from some tank or pond, much of which soaks into the soil. It is not necessary that these ditches should be kept filled with water, for they may be filled from time to time, and the water allowed to soak out. This practice is called surface irrigation to distinguish it from sub-irrigation, by means of which the water is added to the subsoil. Underdrains, usually tile, are put in with the slope running in the opposite direction to ordinary drains, and they are occasionally flooded with water, which soaks through the joints into the soil. This is the most perfect system of irrigation, because there is little or no loss of water through surface craporation. Unfortunately, it is much more costly than surface irrigation, and for this reason but little practiced except in gardens or hothouses.

The flooding of the Nile Valley is an illustration of natural irrigation. This great river annually rises far beyond its banks, flooding a great stretch of country; the mud it brings with it enriches the soil, and much water is at the same time added. The river bottoms are thoroughly irrigated once a year, and are noted for their fertility. There are in our own county great areas of soil that have been robbed of their moisture. The rainfall is too uncertain to make good the loss, and it is only by irrigation that most of the soil may. 
be made fertile. In many parts of the West large traets of country once parched deserts are being converted into fine farming land by means of irrigation.

\section{Questions}

1. What becomes of most seed simply scattered on the surface of the soll? 2. Why is it usually found more profitable to bury the seed? 3 . Why is it better to prepare the soil beiore planting seed? 4 . By what name do we call the process of preparing the soll for planting? 5. What is meant by cultivation? 6. Name two important methods of culilvation that influenco the water supply in solls. 7. What is meant by drainage? 8. Explain how a swamp or marsh is formed. 9. How are open drains made? 10. What is an underdrain? 11. What is a tile-drain? 12. How does drainage benefit the soll? 13. What is irrigation? 14. How does surface irrigation differ from subIrrigation? 15. Which is the more perfect system? 16. Why is it less useci? 17. In what part of the United States is Irrigation most practiced? 


\section{CHAPTER XXIII.-Cultivation of Soils}

\section{(Contineted)}

115. Surface Cultivation of Soils.-Surface cultivation means the pulverizing of the surface soil preparatory to planting seed, or else the working of the crop after it has begun to grow. The preparation of the soil for seed planting is usually accomplished by plowing. Spading, while it is more efficient than plowing, is too expensive to practice on a large scale, and is resirted to only for gardens.

116. Plowing.-Some form of plowing is almost the universal method of cultivation, and the plow most generally used in this country is the turn plow; that is, a plow which turns over the first four to six inches of soil. One disadvantage of this fnrm of plow is that it cuts usually to the same depth, and after many plowings the soil over which the bottom of the plow is dragged is apt to become packed, forming what is salled a HARD-PAN. This hardened layer of earth is difficult for the roots of plants to penetrate, and also interferes with the movement of water in the soil. It may be broken up by changing the depth of plowing, which can be most easily effected by the use of the subsoil plow. The subsoil plow follows immediately in the furrow of the ordinary plow, and breaks up and loosens the subsoil. Subsoil plowing is of benefit when the subsoil has a tendency to become hard. 
The plow does not always put the soil into proper condition for planting. After plowing, some soils are full of lumps and clods, which, unless broken up, serionsly interfere with the growth of the roots of young plants. Such soils are harrowed or rolled for the purpose of breaking up the clods and producing an even surface.

\section{Cultivating the Soil for Planting.-The pri-}

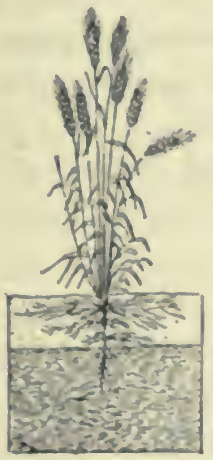

FIO. 19.-Plant growing in shal. low. porly culte. vated sull. mary object in surface cultivation is to prepare the soil for seed planting. The pulverized surface offers a safe place for the germination of the seed, and is easily penetrated by the young roots. A hard, lumpy soil, on the other hand, offers a poor shelter for seed, toll.

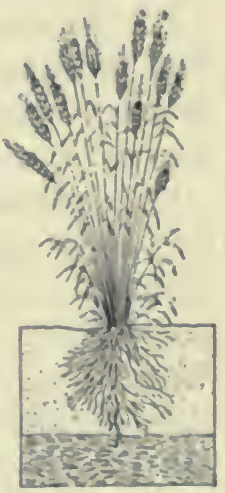

F I 0. 20,-P I \& $n$ t growing in deep, frell-cultivatod

and retards the development of the roots, prodncing weak, sickly plants. The roots of most cultivated plants are soft and delicate, and are entirely nnable to penetrate hard soils; under such eonditions they grow slowly and fail to supply the plant with the food necessary for its perfect development. Fig. 19 represents a plant growing in a shallow, poorly cultirated soil, and Fig. 20 represents the same kind of plant in a deep, well-cultivated soil. 


\section{Effect of Cultivation on the Water Supply of} Soils.-Besides-preparing the soil for the development of plant roots, cultivation has a marked effect on the water supply of soils by increasing the number and reducing the size of the soil particles. The effect of the number and size of the soil particles on film moisture has already been described in Chapter XVII, and the effect of drainage on the free water in Chapter XXII.

119. Aeration.-Surface cultivation also admits a freer circulation of air in the soil, by making the surface more open or porous, thus supplying oxygen for the roots of plants and for the soil bacteria.

120. Cultivation Destroys Insects and Weeds.-Of the many kinds of insects that feed on cultivated crops there are a number that build their nests in the ground, where their eggs are deposited to be hatched out by the spring sunshine. Cultivation destroys these nests, bringing many insects and their eggs to the sur-• face, where they are eagerly devoured by birds or killed by exposure to the weather.

Many soils are covered by a growth of weeds which, when plowed under, rot and add to the soil a supply of humus and nitrogen. If left to grow these weeds seriously interfere with the growing crops.

121. When to Cultivate.-There is great difference of opinion as to whether soils to be planted in the spring should be plowed in the fall and allowed to lie bare all winter, or else plowed a short time before planting the crop. As a matter of fact, the time of plowing should be regulated by the character of the soil. Soils that have a tendency to wash should never 
be left bare during the winter, but should be by some mens protected from the winter rains. There are few soils that will not be improved by having their surface protected during the winter months by growing crops or mulches. Heavy elay soils may, however, be improved by fall plowing; as they often have a tendency to form clods or lumps which are broken up during the winter by the action of the weather. Fall plowing is also of benefit by destroying insects and weeds.

122. Cultivating the Crop.-After crops have begun to grow they are often cultivated for the purpose of destroying weeds which spring up along with the crop and rob the soil of much food. Such cultivation should consist in frequently stirring the surface of the soil with a cultivator, harrow, or hoe, care being taken not to cultivate deep enough to injure the roots of the growing crop. Plowing corn and hoeing tobacco or cotton are familiar operations to all who have spent any time on a farm. Now, besides destroying weeds, this surface cultivation is of much benefit to the crop in another way. Surface evaporation of film moisture, you remember, takes place rapidly from exposed soils, and the method of cultivation of the three crops just mentioned leares the soil somewhat bare; at least such is the ease during the first few months of the crops' growth. The surface cultiration stirs up the first few inches of soil, which dry ont rapidly and form a sort of natural covering or mulch for the soil. It thus serres as a check on surface eraporation, and has the 
same effect as covering the soil with a layer of dry earth.

Crop cultivation also serves to open up the soil to a freer circulation of the air which supplies oxygen. to the growing roots.

123. Terracing.-There are two methods of treating soils to prevent excessive surface washing that are especially applicable to steep hillsides. Terracing means that the hillside is so cultivated as to form a series of large steps or terraces, and the slope between

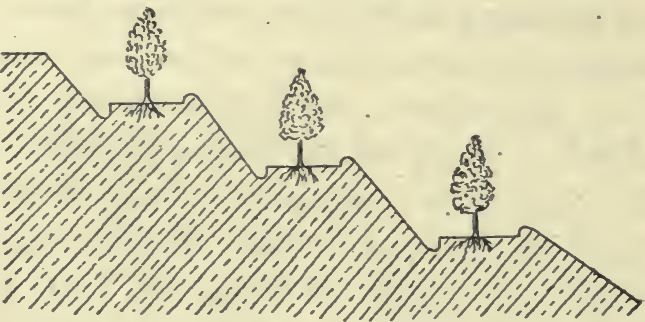

FIG. 21.-Terraced hillside, with ditches for irrigating; fruit trees planted on the terraces.

the terraces planted in grass or some thick-growing crop to prevent.washing. Fig. 21 shows how a hillside may be terraced and planted in trees. This is of course an expensive method of protecting hills, and a simpler and equally as applicable method is to construct a succession of smaller terraces about the hill-two good furrows forming a terrace a foot or two wide are sufficient. These are allowed to grow up in grass and serve to check the formation of gullies.

\section{Questions}

1. What is meant by surface cultivation of soils? 2. What is the most common method of surface cultivation? 
3. What is the most common form of plow? 4. Explain one serious disadvantage of this form of plow. 5. How may this trouble be remedied? 6 . Why will not a plant grow well in a coarse, rough soll? 7 . Why do plants as a rule develop best in well cultivated solls? 8 . What effect has good cultivation on the film moisture in solls? 9. How does cultivation affect the oxygen supply of solls? 10. How does cultivation destroy weeds and insects? 11. How may fall plowing benefit heavy clay solts? 12. Under what condition is it advisable to plow in the fall solls that are to be planted in spring? 13. Why are young crops cultivated? 14. How does surface cultivation prevent surface evaporation? 15. What is meant by terracing? 16. How does terracing protect solls? 


\section{PART IV.-MANURTES}

\section{CHAPTER XXIV.-Classification of Manures}

124. Definition of Manures.-The dictionary defines a manure as anything that may be applied to a soil to make it more fertile.

Manures may be conveniently divided into two classes, Natural manUREs and manUfactured MANURES; the latter class being called COMMERCIAL FERTILIZERS.

125. Natural Manures.-These are substances occuring naturally, and which are not manufactured specially for use as manure. Marl, gypsum and some forms of potash salts are natural manures, as are wood ashes, swamp muck, dead leares or straw, and, best of all, stable manure. There are some by-products, such as cottonseed-meal and sulphate of ammonia, which, while not manufactured specially for fertilizers, are usually classed with other manufactured products.

1. Marl is a kind of soft earth, a mixture of sand with varying proportions of clay and carbonate of lime, with sometimes additions of potash and phosphoric acid. Some kinds found in New Jersey and Virginia are rich in phosphoric acid and potash, and are much used as a fertilizer. Marls, as a rule, are used.only in the immediate neighborhood of their occurrence. Being bulky, the cost of transporting them 
is too great to yield a profit from their sale. The chief use of marls is to supply lime to soils.

2. Gypsum, which when ground up is known as landplaster, is a compound of ealcium, oxygen and sulphur. It is a soft, white substance ensily ground up to a powder. Gypsum is used to supply lime to soils.

3. Wood ashes were formerly much used as a fertilizer, but now as wond has become more raluable less ashes are produced than formerly. Wood ashes are exceedingly valuable for manure, as they contain all the mineral elements necessary for plant food. Wood ashes all contain a notably large proportion of potash.

4. Swamp muck is the rich, dark mud that accumulates in the bottom of ponds and swamps. It is rich in organic matter, and is sometimes applied to soils poor in humus.

5. Wood's mold is formed by decaying leaves and branches from forest trees, and is used for enriching gardens and hotbeds.

6. Dead leares, straw and such waste products may all be used to supply organic matter to soils.

\%. Barnyard manure is often classed with stable manure, though really quite a different product. It is the manure that accumulates in small lots where eattle are kept and fed, and consists of the droppings of the eattle mixed with the bedding supplied them. The value of such manure depends both on the bedding and the drainage of the lot. When the bedding is thin, and the lot well drained, rain water washes away many valuable products from the manure. If, on the other 
hand, the lot is well bedded and undrained, the resulting manure is nearly equal in value to stable manure.

8. Stable manure accumulates in stables where animals are kept and fed, and, like barnyard manure, is made up of the droppings of animals and the bedding supplied them. In some stables the manure is allowed to accumulate, fresh bedding being added from time to time, until the proper season to apply it to the soil. The stables are cleaned out occasionally each year, and during the intervals the manure accumulates in the stalls: Manure formed in this. way has a high value; being kept in the stable it is protected from the leaching of rain, and, becoming well packed by the feet of the animals, is protected from destructive fermentation caused by bacteria. The value of stable manure depends in a large measure on the kind and amount of bedding used, the age and kind of animal, and the kinds and amount of food supplied them. Manure from young animals is, as a rule, less valuable than manure from maturer animals. As the liquid portion of manure contains most of the nitrogen it is important that enough bedding be used to absorb and retain it.

When stables are cleaned at short intervals, and it is found necessary to keep the manure some time before it is applied to the soil, some measure for protecting it from the action of the weather must be adopted or a loss of valuable compounds of nitrogen results. When manure is thrown out it quickly becomes hot, and a loss of ammonia results. Anyone familiar with stables has noticed how warm a manure pile may become, and 
that a smell of ammonia is often noticeable. This means a loss of much valuable nitrogen, and should, if possible, be prevented.

The loss of ammonia from manure piles is caused by the action of a certain class of bacteria, which destroys the organic matter of manure, forming ammonia which passes off as a gas. If the manure pile be properly protected the ammonia is retained and changed into nitrates. The best known method of protecting ranure is to compost it. In all cases the manure pile should be under a shed or covering of some sort to protect it from the weather.

126. Composting.-The decay of manure is always caused by the action of bacteria, and as the manure is warmed the action of the bacteria becomes more rapid. If the manure pile be thoroughly moistened, nitrates are formed by the bacteria just as they are formed in the soil when nitrification takes place. If, however, the warm pile has been exposed to the sun and weather, and has dried out no nitrates are formed, but in their place compounds of ammonia which escape into the air. An unprotected manure pile may in this way become in a short time of almost no value. The nitrates which are formed are easily soluble, and unless absorbed in some way are rapidly drained away from the manure. When nitrates are formed in the soil, if not taken up by plant roots they are partly absorbed and retained by the soil itself; hence the practice of mixing ordinary earth with manure to form a compost heap. First a bed is provided from which no drainage can take place, and on this is spread a layer of manure. 
The manure is covered with a layer of earth, another layer of manure placed on the earth, and this in turn covered. The compost heap is made up of alternate layers of manure and earth, the earth layers absorbing the nitrogen compounds formed in the manure. For the earth may be substituted plaster, the old mortar from buildings, or swamp muck. The manure may have mixed with it old straw or hay, dead leaves and any other refuse matter that can be utilized. Before applying to the soil the compost heap should be thoroughly worked over and fermentation allowed to.start.

\section{Questions}

1. What is a manure? 2. Into what two classes are manures divided? 3. Name some well-known natural manures. 4. What is marl? 5. Why are marls applied to soils? 6. What is gypsum, and why is it used for a fertilizer? 7. Why are wood ashes valuable as a fertilizer? 8. What is swamp muck, and what makes it valuable as a fertilizer? 9. What part of wood's mold, rotting straw, or dead leaves is of value as a fertilizer? 10. What is barnyard manure? 11. On what does the value of barnyard manure mainly depend? 12. What is stable manure? 13. Why is stable manure which is allowed to accumulate in the stable of more value than that which is thrown out into the weather? 14. What causes the loss of ammonia from manure piles? 15. How may the loss of nitrogen be prevented? 16. Tell how a compost heap is made. 17. What substances besides manure may be used in forming a compost heap? 


\section{CHAPTER XXV.-Commercial Fertititers}

\section{Definition of Commercial Fertilizers.-Artificial} manures, or commercial fertilizers, are such sompounds as are manufactured expressly for use on soils. They may be divided into three classes: 1 . Nitrogexous fertilizers, including such eompounds as are used to supply nitrogen. 2. Potassic fertilizers, compounds supplying potash. 3. Pноsmates, compounds supplying phosphorus.

128. Nitrogenous Fertilizers.-Nitrogen compounds are the most expensive of all fertilizers, and as nitrogen is often lacking in soils these fertilizers are of the first importance. The nitrogen of fertilizers is supplied by a number of different compounds, and the more important of these will now be briefly described:

1. Sodium nitrate, often called Chile saltpetre, is a compound of nitrogen with sodium and oxygen, containing about 16 per cent of nitrogen. It is a salt and resembles in appearance ordinary table salt. It occurs naturally in great deposits, the best known of which are in Chile; hence its name. It is very impure when mined, and before it can be used as a fertilizer must be purified. The crude salt is dissolved in water which is afterwards evaporated, when the purified compounds deposit in the form of small crystals. Nitrate of soda is easily soluble in water, and as plants take up their nitrogen in the form of nitrates, it is ready for the use of plants as soon as dissolved in the soil water. 
2. Sulphate of ammonia is another salt containing* nitrogen, and is used to some extent as a fertilizer. It is made up of the elements nitrogen, hydrogen, sulphur and oxygen, and contains about 20 per cent of nitrogen. Sulphate of ammonia is produced as a byproduct by gas works which manufacture illuminating gas for cities and towns. It is easily soluble in water, but in the soil must be changed to a nitrate before it becomes plant food.

Nitrate of soda and sulphate of ammonia are the only salts of nitrogen used for fertilizers. A large part of the nitrogen of fertilizers comes from organic compounds, such as cottonseed-meal, bones, dried blood, fish scrap, etc.

3. Cottonseed-meal is a by-product from the manufaciure of oil from cottonseed, and is now produced in immense quantities. In the oil mills the cottonseed first have the hulls-the hard outer shell from which the lint grows-taken off by machinery. The soft inner portion of the seed, called the kernel, is then heated in immense kettles, after which process it is pressed much as apples are pressed for cider, only the presses are much more powerful. Host of the oil which the seed contains is pressed out by this process, and the remainder of the kernels formed into a flat cake which from the great pressure is as hard as a board. In this form it is called cottonseed-cake, and before it can be used must be ground up in mills, from which it comes as cottonseed-meal, a substance of a rich, golden yellow color, and about as coarse as corn-meal. Great quantities of cottonseed-meal are produced 
each year by the oil mills of the South, and each year more of it is being used for a fertilizer, especially in the cotton States. Cottonseed-meal contains from 7 to 8 per cent of nitrogen, and, besides this valuable plant food, contains 1 to 2 per cent of phosphoric acid, and $1 \frac{1}{2}$ to 3 per cent of potash. When applied to the soil it decays rapidly, and, besides the plant food it contains, it supplies the soil with much valuable organic matter which goes to form humus.

4. Bones of animals are another source of nitrogen for fertilizers. At the bone-yurds of large cities, where great numbers of dead animals are taken, and at the slaughter-houses, where animals are prepared for market, immense quantities of bones accumulate. A part of these bones is ground up and sold as a fertilizer under the name of RAW GROUND BONE. The raw bone decays very slowly, and requires a long time before it is fit for plant food. Bones are often steamed or cooked for the purpose of making glue or oil, and the portion remaining after this process is sold as STEAMED BONE. It decays more rapidly in the soil, and is of more value as a fertilizer. Raw ground bone contains $2 \frac{1}{2}$ to $4 \frac{1}{2}$ per cent of nitrogen, steamed bone $1 \frac{1}{2}$ to $2 \frac{1}{2}$ per cent. Besides nitrogen, bones contain much pliosphoric acid, and are classed as phosphatic fertilizers.

5. Dried blood is a product of the slaughter-house, where quantities of it are dried and sold as a fertilizer. Its value depends on its nitrogen, of which it contains from 10 to 12 per cent. It decays rapidly in the soil, and makes a valuable fertilizer.

6. Tankage is another product of the slaughter- 
house, and is made up of the refuse parts of the slaughtered animals. It contains from 10 to 12 per cent of nitrogen.

\%. Fish scrap is a by-product from the fish canneries, where large quantities of fish are preserved in cans for the market. The refuse parts of the fish are dried and sold as a fertilizer. It contains from 7 to 9 per cent of nitrogen.

129. Potash.-Until about forty years ago all the potash of fertilizers was supplied by wood ashes, stable manure, and waste products, such as rotting straw or. tobacco stems. About the year 1860 there were found in Germany, near the town of Stassfurt, great deposits of potash salts, which were probably left there by the evaporation of some inland sea or lake. Great quantities of these potash salts are now mined and sold, the Stassfurt mines supplying potash to the entire world. The potash salts as found.in the mines are mixed with various other compounds, such as common salt, magnesium chlorides, epsom salts, etc. From this mixture pure potash salts are prepared.

1. Kainit is the crude salt as it comes from the mine and contains a number of different compounds. Most of the potash in kainit is in the form of a sulphate; that is, it is combined with sulphur and oxygen. It contains only about 12 per cent of potash.

2. Sylvinit is another of the crude salts, and most of the potash it contains is in the form of a chloride. Sylvinit contains from 15 to 20 per cent of potash.

3. Muriate of potash, which is manufactured from the crude salts, such as kainit, is a compound of potas- 
sium with chlorine, and is more properly called potassium chloride. It is one of the best known potassium fertilizers, and contains about 50 per cent of potash. .

4. Sulphate of potash is a compound of potassium with sulphur and oxygen, and is also manufactured from the crude potash salts. It contains about the same amount of potash as the muriates, and is much used as a fertilizer.

\section{Questions}

1. What are commercial fertilizers? 2. Into what three classes may they be divided? 3. What two inorganic substances supply nitrogen compounds for fertlizers? 4. Why is nitrate of soda called Chlle saltpetre? 5. When is nitrate of soda sultable for plant food? 6. Tell what you know about sulphate of ammonia. 7. How is cottonseed-meal obtained from cottonseed? 8. About how much nitrogen does cottonseed-meal contain? 9. With what other valuable compound does it supply the soll? 10. Name four other organic substances used to supply nitrogen. 11. From what country do most potash salts come? 12. Name two of the crude products, and tell how much potash each contalus. 13. What is murlate of potash, and how much potash does it contaln? 14. What is sulphate of potash. and how much potash does it contain? 


\section{CHAPTER XX́VI.-Commercial Fertilizers}

\section{(Continued)}

130. Phosphates.-The phosphates of fertilizers comes from two sources: (1) The great deposits of rock ophosphate; (2) The bones of animals.

\section{Where Phosphates are Found.-Phosphate rock} is found in many parts of the world. In Canada there are large deposits of mineral phosphates called Apatite. In the United States great quantities of phosphates are found, the best known deposits occurring in the States of North Carolina, South Carolina, Florida and Tennessee. In the United States the deposits are known as PHOSPHATE ROCK.

Phosphate rock varies greatly in appearance and composition, and occurs sometimes as pebbles in bottoms of rivers, sometimes as boulders scattered through the soil, and again as great beds of rock resembling beds of limestone. In the States of South Carolina, North Carolina and Florida the deposits of phosphates are, as a rule, found near the coast. The so-called river rock is dredged from the bottom of rivers, some in the form of water-worn stones, and some in boulders of various sizes, which are taken from the mud of the river bottoms. "The land rock occurs in masses varying in size from small stones to boulders weighing many tons. 
132. Appearance of Phosphate Rock.-In appearance phosphate rock varies greatly. The soft, white phosphates of Florida resemble marl, and are nearly as soft. The Tennessee rock, as a rule, is hard and resembles in appearance ordinary limestone. The ordinary South Carolina rock is between these two extremes, being of a dirty gray color and moderately hard.

\section{Composition of Phosphate Rock.-All phos-} phate rock, wherever it occurs and whatever its appearance, contains some compounds of phosphorus, and its value as a fertilizer depends on the amount and condition of these compounds. Most of the rock used for fertilizers contains phosphorus combined with calcium and oxygen, which compound is known as calcium phosphate or bone phosphate. Some samples of phosphate rock contain as much as 98 per cent calcium phosphate, and some rock contains almost none at all. Good rock should contain at least 50 per cent of calcium phosphate. Part of the phosphorus may be combined with iron and aluminum, and is then known as iron and aluminum phospliate. The best grades of rock contain but little iron and aluminum, but in some varieties of rock all the phosphorus is combined with these two elements. Such rock, while of some ralue for fertilizers, is not nearly so valuable as the calcium phosphate rock.

Besides compounds of phosphorus, phosphate rock contains rarying quantities of sand, organic matter, iron and sulpl:ur, and minute quantities of several other substances. 


\section{Manufacture of Commercial Phosphates.-The} phosphorus compounds in phosphate rock are practically insoluble in water, and before they can become plant food must be changed into soluble compounds. Where phosphate rock is applied to soils the weak acids in the soil gradually change the insoluble phosphates into soluble compounds, but the change is slow at best. Now, strong mineral acids, such as sulphuric acidoil of vitrol-have the same effect as the weak soil acids on the insoluble phosphates, changing them into soluble compounds, and the stronger the acid the more rapid the change. This fact is taken advantage of in the manufacture of phosphates, and the process is briefly as follows: The phosphate rock, after being cleaned, is ground to a fine powder in powerful mills, and this powder mixed with strong sulphuric acid. When the acid is mixed with the dry powder it first forms a sticky mass like stiff mud; this is thoroughly worked up and allowed to stand in order to give the acid time to change all the insoluble compounds into soluble. The sulphuric acid in changing the phosphate compounds is itself changed into calcium sulphate, or gypsum. The change in the sulphuric acid is necessary, for the acid itself destroys all vegetation, and any unchanged acid would ruin the fertilizer. The amount of acid necessary to form the soluble phosphates is carefully determined beforehand, and the right amount added. After the mixture has stood the proper length of time it becomes about as dry as ordinary soil, and all the acid is neutralized, i.e., changed into sulphate. The phos- 
phate is now placed in sacks and sold as ACID PHOSPHATE, DISSOLVED BONE, DISSOLVED ROCK, etc.

There are three kinds of phosphorus eompounds in acid phosphate, and they are known as: (1) Soluble PHOSPHORIC ACID, which is easily soluble in water; (2) REVERTED PHOSPHORIC ACID, which is easily soluble in weak acids, such as are found in the soil; (3) INSOLCBLE PHOSPHORIC ACID, which is soluble in strong acids. The insoluble phosphoric acid is part of the original ground rock which has not been acted on by acids; it forms but a very small part of good fertilizers, seldom above 1 per cent. The soluble and reverted phosphoric acids are classed together as AVAILABLE PHOSPHORIC ACID. The sum of the available and insoluble gives what is called the TOTAL PHOSPHORIC ACID.

135. Bone Phosphate.-The bones of all animals contain large amounts of phosphate of lime, and are much used for fertilizers. When the bones are simply ground and sold for a fertilizer the product is known as raw bone, and nearly all of the phosphoric acid it contains is insoluble. The steamed bone, while it is made up principally of insoluble phosphoric acid, deeays much more rapidly in the soil, and for this reason is of more value as a fertilizer. As a large part of the organic matter has been removed by the process of cooking, steamed bone contains more phosphoric acid than raw bone. Raw bone contains 20 to 25 per cent of phosphoric acid, or 43 to 54 per cent of bone phosphate. Steamed bone contains 22 to 29 per cent of phosphoric acid, or 48 to 63 per cent of bone phosphate. 
136. Valuation of Fertilizers.-Commercial fertilizers are valued according to the amounts of nitrogen, phosphoric acid and potash they contain, and, in order to protect the consumer from dishonest manufacturers, most States have employed chemists whose business it is to examine all fertilizers sold in their State, to see if they contain what the manufacturers claim for them. Each package of fertilizer sold must have printed on it the amounts of nitrogen, phosphoric acid, and potash it contains, so that buyers may know what they are getting. Each State chemist fixes a value per pound for nitrogen, phosphoric acid and potash, and with them anyone may calculate the value of any commercial fertilizer. Suppose, for instance, that nitrogen is valued at 15 cents a pound; then if a fertilizer contains 2 per cent of nitrogen its supply is worth $\$ 6.00$ per ton. If the fertilizer contains also 8 per cent of available phosphoric acid which is valued at 4 cents a pound, its supply of phosphate is worth $\$ 6.40$ per ton. If, besides nitrogen and phosphoric acid, the fertilizer contains 1 per cent of potash valued at 5 cents a pound, its potash is worth $\$ 1.00$ per ton, making a ton of the fertilizer worth $\$ 13.40$.

Nitrogen, $2 \%$ of $2,000 \mathrm{lbs} .=40 \mathrm{lbs}$. at $15 \phi$ per $\mathrm{lb} .=\$ 600$ Phosphoric acid, $8 \%$ of $2,000 \mathrm{lbs} .=160 \mathrm{lbs}$. at $4 \xi$ per

$\mathrm{lb} .=$

Potash, $1 \%$ of $2,000 \mathrm{lbs} .=201 \mathrm{bs}$. at $5 \dot{\xi}$ per lb. $=\quad 100$

The valuations placed on nitrogen, phosphoric acid and potash by official chemists are bașed upon the 
wholesale prices of these substances at points of supply. For instance, if nitrate of soda sells for $\$ 48$ a ton, and contains 16 per cent of nitrogen, then its nitrogen is worth 15 cents a pound. If cottonseed-meal sells for $\$ 18$ a ton, and contains 6.75 per cent of nitrogen, then its nitrogen is worth 13.3 cents a pound. In the same way, values are fixed for the phosphoric acid and potash supplied by various substances. - These values are usually fixed once each season, and remain unchanged until the next season.

When the various substances supplying nitrogen, phosphoric acid and potash are mixed to form a complete fertilizer-that is, a fertilizer containing all of these plant foods-the valuations of the official chemists may be used to estimate the cost of the raw materials, as in the example already given. The selling price of the fertilizer is, howerer, often greater than the estimated value of the raw materials, because the manufacturer charges enough to insure himself a profit after paying the cost of manufacturing and of placing the fertilizer on the market.

Neither the valuation of the official chemist nor the market price indicates, however, the agricultural value of any fertilizer, for its agricultural value can be determined only by actual tests in the field. The published analyses and the official valuations of fertilizers are, however, of benefit to the farmer in several ways.

They show, first, what the composition of a fertilizer is, and whether it fulfills the claims of the manufacturer. Next, by showing the farmer how to calculate for himself the market value of the guaranteed con- 
stituents of a fertilizer, they enable him to tell whether the manufacturer is charging too much for his article, and what are the relative values of different brands of fertilizers. And, finally, they warn the farmer that there is very little in a name or brand, for in not a few instances manufacturers have been known to sell the same article under many different names or brands.

\section{Questions}

1. From what two sources are the phosphates of fertilizers derived? 2. Name the States in which the best known deposits of phosphate rock are found. 3. What is the difference between land rock and river rock? 4. How does the land rock usually occur in the soil? 5. How does the phosphate rock from different localities differ in appearance? 6. All phosphate rock contains compounds of what element? 7. With what two elements is the phosphorus of phosphate rock usually combined and what is the compound called? 8. On what does the value of phosphate rock principally depend? 9. About how much calcium phosphate should good rock contain? 10. With what other elements is a part of the phosphorus combined? 11. How are the insoluble phosphates changed into soluble compounds in the soil? 12. Describe the process of manufacturing soluble phosphates. 13. What becomes of the sulphuric acid used to make soluble phosphates? 14 . What are the soluble phosphates called? 15. What is meant by soluble phosphoric acid, what by available, and what by total? 16. What is the difference between raw bone and steamed bone? 17. About how much calcium phosphate does each contain? 18. How are fertilizers valued?

\section{PROBLEM}

Calculate the value of a ton of fertilizer containing 3 per cent nitrogen, 9 per cent available phosphoric acid, and 2 per cent potash; nitrogen being valued at 14 cents a pound, phosphoric acid at 4 cents, and potash at 5 cents. 


\section{CHAPTER XXVII.-Use of Manures}

137. Purpose of Manures.-The purpose of applying manures is always to increase the yield of cultivated crops. The manures may be applied to furnish food for some one particular crop, or they may be used to increase the fertility of the soil, but in each case the object is the same. Manures that are used to furnish plant food for some one particular crop are called SPECIAL ManUres. Manures that are used to improve the condition of the soil are called GENERAI MANURES. For special manures only such compounds as furnish easily available plant food are used. For general manures substances are used which increase the store of plant food in the soil, either by being gradually changed intn plant food themselves, or by forming available compounds with the unavailable plant food already in the soil. The process of increasing the fertility of worn soils is called sOIL RESTORATION.

138. Restoration of Worn Soils. - A worn soil is one that for some reason fails to produce profitable crops. This failure to produce crops may arise from poor cultivation, or it may be that one or all of the different compounds supplying available plant food are lacking; but whatever the cause, the trouble should be known before a cure is attempted. The successful physician always learns, if possible, the nature of his patient's illness before attempting a cure, and so should those 
who expect to cure sick soils know the cause of the trouble before applying remedies.

There are many ways in which a soil may become poor, but, as already pointed out, the loss of moisture and organic matter is the chief cause of poor soils. Therefore, in improving a poor soil, the first point to be inquired into should be its supply of water and organic matter. A soil well supplied with organic -matter is, if well cultivated, usually well supplied with water and plant food; so it is safe to begin the improvement of worn soils by looking to the supply of organic matter. Increase the soil's supply of organic matter, and you increase its supply of moisture and plant food. The usual method of increasing the soil's store of organic matter is to grow some crop and plow it under while it is growing. Leguminous crops, such as clover and beans, are the best for the purpose, as they gather from the air stores of nitrogen which, when they decay, are added to the store in the soil. The plowing under of growing crops is called GREEN MANURING, and is much practiced on worn soils. The green crops, decaying in the soil, form valuable compounds of nitrogen and humus. The humus increases the soil's power to hold water, and combining with the insoluble phosphates and potash compounds in the soil forms available plant foods. As the organic matter of the green manure decays slowly, and the humus which is formed acts slowly on the insoluble compounds, the good effects of one application of green manure may last throughout several years. For green manuring there is no better crop than the old-field pea, 
or cowpea. It will grow in a very poor soil and add greatly to its store of nitrogen.

The addition to the soil of stable manure accomplishes the same purpose as plowing under green crops; indeed it does more, for it adds to the soil some useful compounds of phosphorus and potash and a host of useful bacteria. Stable manure is both a special and general manure; it adds to the soil compounds that soon become available for plant food, and also gradually improves the condition of the soil. Stable manure is probably the most valuable of all manures, and may be used to great advantage on most soils. It should be regarded as one of the most valuable products of the farm, and should never be wasted.

Organic matter and moisture, however, are not the only plant foods that may be lacking in poor soils; some one or more of the mineral elements may be wanting. Thus there are soils in which the supply of lime has become exhausted, and where this is the case the soil, from the accumulation of humus acids, usually becomes sour. This acidity may be correeted by the application of lime. Soils rich in decaying organic matter are often improved by an application of lime.

The total supply of phosphoric acid and potash in soils is seldom exhausted, though such cases do occur. The arailable phosphoric acid and potash, on the other hand, are often exhausted, and must be renewed either. by the application of a fertilizer, or by treating the soil 80 as to render the insoluble compounds available.

When a soil becomes worn and poor it should be carefully examined, and, if possible, the cause of the 
trouble ascertained; then the proper course of treatment may be determined on. It is no simple matter to restore the fertility of a worn soil, and there are no fixed rules to be followed; each individual case must be carefully studied and treated. Very often the proper treatment can be determined only by experiment.

139. Special Manuring.-In using special manures the manure is added for the benefit of some one particular crop, and it is of more importance to know the needs of the crop in question than it is to know the needs of the soil. For instance, clover and cowpeas are crops which require large amounts of nitrogen compounds for their production, but which are able to draw on the atmosphere for a large part of their needs. It is therefore useless to supply such crops with nitrogenous manures. The soil may be very poor in nitrogen, but that is of little consequence so far as these crops are concerned; they are to a certain extent independent of the soil for their nitrogen supply. Again, 1,000 pounds of tobacco leaves require for their production 40 pounds of potash and only 3.4 pounds of phosphoric acid. It is evident that tobacco requires for its production more potash than phosphoric acid, and we may use this knowledge in preparing a fertilizer for use on this crop.

When manures are applied to increase the yield of any particular crop, it is the crop that is to be fed, and not the soil. By analyzing the crop in question we may learn the amounts of plant food it requires for its production. Now, it would seem an easy matter to analyze the soil and find out what it lacks in the way of plant 
food, and with this information and the knowleage of what the crop in question requires, apply the proper amounts of the fertilizers. The difficulty in the way is, that while it is possible to determine with considerable accuracy how much nitrogen, phosphoric acid, potash, lime, etc., a soil contains, there is no accurate method for determining just how much of each of these substances is in available form for plant food. We may find by analysis that a soil contains .5 per cent of potash, but for all we know from the-analysis, the total amount may be unavailable for plants. On the other hand, we do know from accurate analyses just how much plant food is required to produce any single crop, and can use the knowledge to advantage in applying fertilizers.

But different plants vary greatly in their power of procuring their food supplies from the soil; one, for example, requiring large amounts of potash may be able to obtain its supply of this constituent much more easily and readily than another requiring a smaller amount of it. In such cases analysis is not a safe guide.

No fixed rules can be laid down for the use of manures; different crops require very different treatment, and even the same crop under varying conditions of soil and climate takes up varying amounts of plant food. The only reliable way of determining what different crops require in the way of plant food is by experiment. Every farmer must determine for himself the kind and amount of fertilizer his crops require, and in doing this he may be greatly aided by a knowledge of the composition and habits of growth of the crops. 


\section{Questions}

1. What is the object in applying manures to soils? 2. What is meant by a general manure? 3. To what kind of soils are general manures usually applied? 4. When is a soil said to be worn? 5 . In restoring a worn soil what is the first thing to be considered? 6. Name two of the chief causes of poor soils. 7. What is the usual method of increasing the organic matter in the soil? 8. What is the process called? 9. How does the plowing under of a green crop improve a poor soil? 10. Why is stable manure of benefit to poor soils? 11. What are the best crops to use for green manure? 12. What effect does the loss of lime have on the soil? 13. How may acid soil be improved? 14. What is meant by a special manure? 15. Special manures should contain the plant food in what form? 16. How does a knowledge of the composition of crops aid in determining the application of special manures? 17 . Why can you not lay down fixed rules for the application of manures? 


\section{PART V.-FArM CROPS}

\section{CHAPTER XXVIII.-Seed 'Testing}

140. Primary Object of Agriculture.-Professor S. IV. Johnson, one of our foremost writers on agricultural subjects, thus defines the object of agriculture: "The object of agriculture is the production of certain plants and certain animals which are employed to feed, clothe and otherwise serve the human race. The first aim, in all cases, is the production of plants."* The successful farmer should then strive to produce, at the smallest possible cost, the largest crops of certain plants. In order to produce the largest erops he must know something of the habits and needs of the plants in question. It would be unwise to attempt to grow rice or cotton in Maine, or sugar beets in Florida; nor would it be advisable to attempt to grow celery in a dry, sandy soil, or swcet potatoes in a cool, damp soil. Each plant has its preference in regard to soil and climate, and each requires for its proper growth and development certain kinds of plant food. The study of agriculture among other things endeavors to find out the various requirements of different farm crops, and to make rules for their cultivation which, if properly observed, will produce the largest possible crop at the least cost.

- How Crops Grow, by S. W. Johnson, page 1. 


\section{General Farming and Special Farming.-On} many farms are produced each year several different kinds of crops; such as wheat, corn, tobacco, and oats. This practice is called general FARMing. But gradually the production of one main crop on each farm is becoming customary. In addition to such crops as are needed to feed themselves and their stock, many planters raise for the market only one main crop, as for example, cotton, rice, or tobacco. This is called SPECIAL FARMING. The kind of crops the farmer raises is usually. determined by his soil and climate, and by the demands of the market.

142. Selecting Seed.-After determining on the kind of crop to be planted, and after preparing the soil in which to plant it, the next important step is selecting the seed; and in doing this it is important to remember that poor seed produce poor crops. Select only good, pure seed for planting. Seed are unfit for planting: (1) When they come from diseased or illshaped plants, (2) when they are not fully matured, (3) when they are too old, (4) when they have been attacked by disease or insects, (5) when they are small and ill-shaped, (6) when they are mixed with other seed or trash.

143. How to Test the Purity of Seed.-The first thing to do is to weigh the seed. The seed of different crops vary in weight, and the weights per bushel for pure seed have been determined for most farm crops. These standard weights are given in a table in the appendix. If the sample of seed to be tested does not agree in weight with the standard, then it is reason- 
able to suppose that something is wrong, and further test should be made. Whatever the weight of the seed, it is well to take a small amount, say an ounce, examine it carefully and pick out all the trash, unsound seed, and foreign seed. Foreign seed mean any seed other than the kind called for by the sample. By weighing the impurities the per cent of pure seed may be determined.

144. Germinating Tests for Seed.-The most important test for sced is determining their power to germinate, that is, their power to grow when planted. The seed may be apparently sound and contain almost no trash or impure seed, and yet fail to grow when planted. Old seed often fail to grow. A simple method of germinating seed was described in the experiment on page 36 , and it is well to test all seed in this way before planting. Take say 50,100, or 200 seed, depending on their size, and germinate them as described in the experiment. By being careful to have all the conditions of temperature and moisture just right, and by noting the number sprouting, the per cent of sound seed may be determined.

145. Necessity for Testing Seed.-It is unfortunately true that many kinds of seed are adulterated, some by accident, others by design. Small seed, such as grass or clover seed, are easily adulterated, and the impurities are difficult to detect. The U.S. Department of Agriculture at Washington has made trials of many kinds of seed, and Fig. 22 shows the result of a test of red clorer seed. Only 46.2 per cent of the seed bought could be relied on to grow when 
planted. "More than one-half of the total was waste, or worse, making the actual cost of the good seed more than double the amount supposedly paid for it."* The maiket price of the seed was $\$ 3.50$ per bushel, but as more than half, 53.8 per cent, of this amount was waste, the good seed actually cost $\$ 7.56$ per bushel. Many examples of this kind might be given to show the necessity for seed testing. Of course all the seed

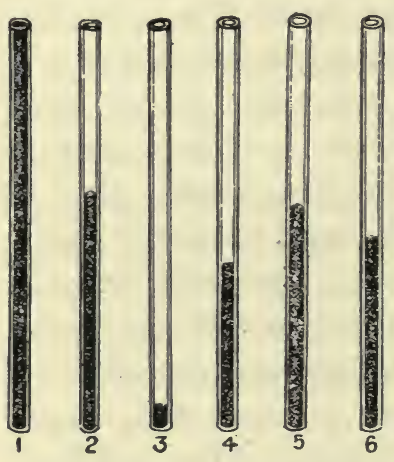

Frg. 22.-Red clover (Trifolium pratense): 1 , one pound of seed as bought; 2, pure seed; 3, broken seed and dirt; 4, spurious seed; 5 , total waste; 6 , pure and germinable seed (From Farmers'Bulletín, No. 111, U. S. Dept. Agr.)

sold on the market are not so bad as the sample used in this test. Some lots of seerl are very good, and contain almost no impurities. On the other hand, there are other lots of seed much worse than the one cited. For example, the U. S. Department of Agriculture found one sample of clover seed that contained only .S per cent of pure, germinable seed. The market price of this seed was $\$ 5.75$ per bushel, but the actual price for the good seed was at the rate of $\$ 703.80$ per bushel.

146. Deterioration of Secd.-Good seed as a rule produce good crops, which, in turn, produce good seed. But this is true only when the crop is grown under favorable conditions. Poorly cultivated crops produce a poorer quality of seed than those from which

*Farmers' Bulletin No. 111, U. S. Dept. Agr., 1900. 
they grow, and the quality is said to deteriorate. Seed from crops grown in a cold climate when planted in a warm climate often produce an improved quality of seed. On the other hand, seed taken from a warm climate to a cold often produce an inferior quality of seed. Good seed deteriorate when planted in unsuitable soils, or in soils not well supplied with the proper plant foods. All farms erops originally grew wild. Man found them useful and cultivated them. By great eare in selecting and planting only the best seed and by thorough cultivation, the quality has been steadily improved and is still being improved. But it is only by constant attention that they are kept up to their improved condition. If neglected they soon become as poor as they were originally.

\section{EXPERIMENT}

Purchase an ounce of grass or cluecr sced from some dealer. With the class, pick wer the seed carefully, squarating the good, sound seed from the trush and foreign seed. Weigh the sample and determine the per cent of sound seed. Sprout 100 of the sound seed and note the number germinating.

\section{Questions}

1. What is the primary object of agriculture? 2. Why is It advisable to know something of the habits of the plants grown for use on the farm? 3. What is general farming? 4. What is speclal farming? 5. After preparing the soll and determining on the kind of crop, what is the next step? 6. In selecting seed, what are some of the points to be considered? 7. How may seed be tested for purity? 8. How may the germinating power of seed be tested? 9. What 
was the result of the test of red clover seed by the United States Department of Agriculture? 10. What is meant by the deterioration of seed? 11. What are some of the causes of the deterioration of seed?

\section{PROBLEM}

Suppose we buy 10 pounds of seed at 14 cents a pound. After testing we find that the lot contains only 46 per cent of seed that will grow. What is the cost of the good seed a pound? 


\section{CHAPTER XXIX.-Classification of Crops:} Cereal and Fodder Crops

147. Classification.-There are so many kinds of crops grown on the different farms of this country that to attempt to describe each one separately would require too much space and time. Fortunately for our purpose many of these crops are alike in their manner of cultivation and growth, and we may arrange the more important farm crops into a few classes.

The grain crops, Indian corn, wheat, oats, rye, barley, etc., are all placed in one class and called CEREAL CROPS. Crops grown for hay, fodder, or pasture are all called FORAGE CROPS. Crops grown for their roots or tubers, such as potatoes, turnips, beets, etc., are called ROOT and TUBER CROPS; and the crops not included in any of these classes are deseribed as MISCEllaneous crops. We have then:

1. Cereal or Grain Crops: Indian corn, wheat, oats, rye, barley, rice, ete.

2. Forage Crops: clovers and grasses for hay, fodder, and pasture.

3. Root and Tuber Crops: beets, turnips, potatoes, etc.

4. Miscellaneous Crops: tobacco, cotton, fruit crops, garden crops, etc.

148. Cereals. - The three important cereal crops of this country are Indian corn, wheat, and oats. Rice 
is also an important grain crop, but its growth is limited to a small section of country. By the word corn in the United States is meant Indian corn or maize. In many foreign countries the word corn means the seed of all cereal plants-wheat, rye, oats, barley, and Indian corn. The word corn' as we shall use it always refers to Indian corn.

The cereal crops are grown for the seed they produce. It is true that both corn and oats are sometimes grown for fodder, but their chief value to man lies in their seed.

Corn, wheat, and oats are found growing in all the temperate regions of the earth, in many different kinds of soil and in many climates. The numerous soils and climates in which the crops grow have produced a number of different varieties; thus we have dent corn, flint corn, popcorn, etc.; red wheat, white wheat, bearded wheat, etc.; and many varieties of oats. But while these varieties differ somewhat in appearance they are very similar in habits of growth and food requirements.

All the cereals are annuals, and have clustered or crown roots, as shown in Fig. 5, page 40. These roots branch out near the surface and spread through the surface soil. Some of the roots penetrate to considerable depths in the subsoil; the roots of winter wheatplants have been known to penetrate the soil to a depth of four feet or more, but most of the roots draw their supplies of food and water from the upper soil. 
The cereal crops grow on almost any kind of soil, but they do best in deep, rich, clay loams which are well supplied with water, but not wet. The ideal soils for cereals are the rich prairie soils of the western United States and eastern Russia. Whatever the kind of soil in which these crops are to be grown, it should be well cultivated in order to give the roots a chance to spread. Hard, rough soils give the roots of cereals no chance to spread in search of food, and the crops suffer in consequence. Light, sandy soils contain neither sufficient food nor water for the cereals. The cereal crops are best planted in drills or rows. When planted in this way a better yield of grain per acre is obtained than if the seed be scattered over the surface.

The cereal crops require an abundant supply of nitrogen, phosphoric acid, and potash, all of which they draw from the soil. If the soil be poor in any one of these plant foods the deficiency must be made good by the use of fertilizers. Fertilizers containing arailable nitrogen, phosphoric acid, and potash compounds are usually found of benefit to the cereal crops. The proper amounts and proportions of these three different substances depend on such a rariety of circumstances that no rules for their use can be stated here.

While corn is classed as a cereal crop, it differs somewhat in its habits of growth from the small grains. Corn is planted in rows some distance apart, and the crop repuires thorough but shallow cultivation during its period of growth. The small grain crops require no cultivation. Corn can draw much of its food from 
the decaying organic matter in the soil, and in consequence stable manure is specially valuable as a manure for this crop.

149. Fodder Crops.-Instead of gathering the seed for food, the entire crop may be harvested and fed to animals. Crops harrested in this way make what is known as fodder. The crop may be gathered before it ripens, and may be fed at once, when it is known as GREEN FODDER; or it may be dried and made into DRY FODDER. The most important fodder crops are corn and oats. Thus corn and oats are important both as cereal and fodder crops.

150. Green Fodder.-When crops are cut before they ripen and are at once fed to cattle the process is known as solling. Any crop fit for cattle food may be used for this purpose-corn, oats, rye, clover, cowpeas, etc. It would require too much space to describe the many advantages claimed by its advocates for this method of feeding cattle; suffice it to say, the method is growing in favor, and when pasturage is scanty may be advantageously practiced.

151. Ensilage or Silage.-Another method of feeding green fodder is to preserve it as ensilage and feed it to stock during the winter months. Ensilage is made by packing away green fodder in buildings or compartments called silos, which are large pits dug in the ground, or air-tight rooms built above ground. The silo most generally used now is built above ground in the shape of an immense barrel. A round silo is shown in the cut of the model barn. (See frontispiece.) The best constructed silos have double walls, between which are layers of paper. The size of the silo is, of course, 
regulated by the amount of ensilage to be stored away. Before the fodder is put into the silo it should be cut up, as in this way a much greater quantity can be stored, and the air more thoroughly excluded. Almost any of the green crops may be used to make ensilage, but corn fodder cut green has been found to be the best crop for the purpose. The crop is best cut after the ears of corn have formed, but before the grains have become hard. If the crop is cut too early the ensilage is apt to become too acid or sour, and if cut when the crop is mature it is somewhat hard and dry.

Just how the ensilage is preserved in the silo is not thoroughly understood, but the simplest explanation is as follows: When the ensilage is first stored in the silo it begins to heat, and the whole mass in a comparatively short time becomes thoroughly warm. Heating always takes place when freshly cut green fodder of any kind is heaped together. Some of the countless bacteria that are present in the air or in the plants themselves are inevitably packed away with the ensilage, and when the mass begins to heat they begin to work, causing fermentation, the first step towards decay. These bacteria are supplied with oxygen by the air that fills the spaces in the mass of ensilage. But the heat generated expands this air and causes much of it to escape through the top of the mass. The ensilage settles and more air is driven out. Between the loss of escaping air and that used up by the bacteria themselves, the supply is soon exhausted, and owing to a lack of oxygen the bacteria cease to work and the ensilage is preserved from further decay. The mass of ensilage 
soon settles, becoming so tightly packed that little or no air can enter. The top of the silo, except for a covering from the rain, may be kept open to the air, and no harm will result. The first few inches of ensilage which are exposed to the air will rot, but the ensilage will be found perfectly preserved bẻlow. A covering of straw helps to preserve the top layer of ensilage. The slight fermentation that has taken place in the ensilage, it is claimed, improves it as a food for stock; but whether this is true or not, ensilage is much enjoyed as a food by all classes of stock.

Ensilage is very valuable as a stock food because it furnishes a supply of fresh food at a season when green food is unobtainable. It is also a very economical way to preserve food, for by this process great quantities of food may be stored in a very small space. The feeding of ensilage during the winter months is beneficial to the health of animals. While ensilage furnishes a valuable food for all classes of stock, it is especially valuable for milch cows. Feeding ensilage to milch cows causes the animals to give a greater supply of milk, and at the same time keeps them in better health.

We learn from Roman writers that the practice of preserving fodder as ensilage is a very old one. It is probable that the process was known to them hundreds of years before the birth of Christ. In this country ensilage is a comparatively new thing, the practice having been begun about 1875 , and was based upon the method then in vogue in France. It rapidly grew in faror until now a silo is part of the equipment of every first-class farm where stock is kept. The 
earlier silos were merely pits dug in the ground, some of them lined with cement; but it was troublesome to dig the ensilage from these pits, and to avoid this the silo built above ground came into use. The modern silo is usually built as a part of the feeding barn, and on a level with the feeding floor. It should always be situated as close as possible to the feeding stalls on account of the labor of handling the ensilage; for it is both heavy aad bulky, and to carry it by hand for long distances adds materially to its cost.

\section{Questions}

1. Name the three most important cereal erops of this country. 2. What part of the crop is of most value? 3. In what parts of the earth are corn, wheat, and oats grown? 4. How have the many different solls and cllmates affected these crops? 5. What sort of roots have the cereals? 6. Name two regions especlally noted for thetr production of grain. 7. What is meant by fodder? 8. What is the difference between green and dry fodder? 9. What is feedIng green fodder called? 10. What is ensllage? 11. What Is a 8110 ? 12. How should the crop be prepared for storage In the sllo? 13. Why should fodder be cut up before storing for ensllage? 14. What happens to the fodder when it is first stored in the sllo? 15. How is the fermentation of the ensilage stopped? 16. Give some reasons why ensllage is of value as a stock fond. 17. About how old is the practice of maklng ensllage? 18. About what year was ensilage first made in this country? 
CHAPTER XXX.-Fodder Crops and Pastures

152. Dry Fod̀der or Forage.-Dry fodder may be divided into three classes: DRY COARSE FODDER, STRAW, and HAY.

153. Dry Coarse Fodder.-After the corn crop has been cut and the ears gathered, the stalk, leaves, and shucks form what is generally known as CORN FODDER; a better name for it is CORN STOVER, to distinguish it from another kínd of corn fodder. When corn is planted thick like wheat or oats, the plants make a fine growth, but the ears do not develop as well as when the crop is planted with greater space between the plants. Corn for fodder is planted thick like wheat, and the crop is cut before the ears are fully ripe; it then makes the true corn fodder. Corn fodder is made from the whole plant, ears included; it is the hay of the corn plant. Corn stover is made from the plant without the ears; it is the straw of the corn plant. Sometimes the ripened leaves only are gathered for fodder; they make what is known as PULLED FODDER or BLADES. Oats, millet, and sorghum are all extensively used for making fodder.

154. Straw.-Straw is that part of the cereal crop which remains after the seed has been gathered. From the corn crop it is known as stover, but from wheat, oats, rice, rye, barley, etc., it is known as STRAw.

Straw is not of great value as a stock food. The 
seed which have been gathered take away most of the valuable food compounds, leaving the straw dry and hard. Straw can, however, be used to advantage as a food, as will be explained later, and is also valuable as a bedding for stock. Old or rotting straw forms a valuable mulch for poor soils.

155. Hay.-When grasses, clovers and similar crops are cut green and dried in the sun they form what we call нау. The hays formed by coarser grasses such as corn and sorghum are called fodder, though they are nothing more than hays. Hay differs from the original green fodder in having lost nearly all of its moisture. Hay, though apparently perfectly dry, contains on an average about 10 per cent of moisture. Of course there are many kinds of hay resulting from the many kinds of forage plants, but we may divide hays into two distinct classes, namely, the hay of grasses and the hay of legumes.

156. Hay of Grasses.-There are many kinds of grasses that may be grown for hay-grasses suitable to different soils and climates. Among the best known hay grasses are timothy, orchard grass, bluegrass, meadow grasses, and, in the South, Bermuda grass. Two or more kinds of grasses may be grown together, and clorer is often mixed with them. The hay from such a mixture is called hay of mixed grasses. Most of the grasses grown for hay are perennials; eacli year the top dies to.the surface soil, but the next spring a fresh growth is sent up by the roots. The grasses grown for hay have much the same kind of roots as the cereal crops and require for their production much the 
same kinds of soils and fertilizers, Fertilizers containing nitrogen often improve crops of grass. Grass crops are often grown immediately succeeding crops of wheat or oats. The soil is or should be already well prepared for the wheat or oats, and the dense growth of these crops checks the growth of weeds, leaving the soil in good condition for grass.

Grass that is mown for hay should not be exposed to the sun for days after being cut. The object in curing hay is merely to remove a part of the water contained in the fresh grass. This is accomplished by a few hours' exposure-to the sun. The hay should then be put into small heaps called cocks; after standing in them for a short time the hay should be stored away in barns or stacks. It is a great mistalie to allow cut hay to lie on the ground for days, or even to allow it to remain for any length of time in cocks. Through the action of the sun and weather the quality of the hay is much injured. The grass after being cut dries out very fast, and the entire process of curing and storing hay should not exceed two days.

Grasses should generally be cut for hay when in full bloom or just passing out of bloom, as at this time the protein and carbohydrates are more uniformly distributed throughout the plant.

157. Hay of Legumes.-Of the plants belonging to the legumes, there are a number that may be used for hay. There are several kinds of clover, a number of kinds of field peas or beans, some of which are known under the name of cowpea. Then there is another kind of pea called vetch, and a plant of the same order 
known as lucerne. There are still other kinds of legumes used for hay, but the two first mentioned, the clover and cowpea, are more generally used in this country than any other.

The leguminous crops used for hay grow in almost all soils and in many climates. Some, however, do best in one kind of soil and climate, while other varieties prefer very different conditions. Clover does not do well in hot climates, nor does it produce profitable crops from poor sandy soils; this crop prefers a good strong soil well supplied with moisture, lime, and potash. The cowpea, on the other hand, does not mature in cold climates, and flourishes best under the hot southern sun. It will make a good crop on soils too poor to produce clover. Light sandy loams, if well - supplied with moisture and mineral plant food, will produce large crops of cowpeas.

All the crops belonging to the pea family have, as you no doubt remember, the power of using the nitrogen of the air for food. They can therefore grow well in soils containing little nitrogen.

These crops are provided with very deep-growing roots which spread to a considerable depth through the subsoil, from which they draw much plant food. The legumes have the power of extracting more food from the soil than either the cereal crops or grasses, and their deep-growing roots enable them better to withstand drought. These crops improve the condition of the soil by adding to its store of plant food, and also make a very valuable hay which is much used as cattle food. The cowpea has been called the "poor 
man's bank"; it might more properly have been called "the poor soil's bank," for from it the poor soil draws fresh supplies of plant food.

Among the legumes are included annuals, biennials, and perennials: The variety of clover usually grown for hay, known as red clover, is in temperate regions a biennial. White clover, the small clover which grows in most pastures, is a perennial; and there is still another kind, known as crimson clover, which is an annual.

Clover should be eut for hay when in full bloom; the peas and beans should be cut when the pods are. formed, but before they become hard. If these crops are allowed to become too old before cutting, the leaves are liable to drop from the stem, and the value of the hay is thereby decreased.

After being cut, leguminous crops should be cured rapidly, for if they are allowed to remain in the sun for many hours they become hard and brittle so that when handled the leares drop away from the stem.

158. Pastures,-A pasture is a field planted in any crop on which animals are allowed to graze. Pastures are of two kinds, permanent and temporary.

159. Permanent Pastures.-Fields on which perennial forage crops are planted and allowed to grow year after year are called permanent pastures. The best kinds of pasture grasses form a very thick, dense growth on the surface of the soil, while below the surface their roots are so matted together that sections of a square foot or more may be lifted from the soil. Such a growth forms what is known as turf or sod. A good turf 
forms a perfect covering for the soil and protects it from surface evaporation, and from the leaching and washing of rains. All grasses will not make good turf; in fact there are comparatively few varieties that form a perfectly even turf suitable for a lawn. On pasture lands, however, while a good turf is an advantage it is not a necessity; any perennial crop that will cover the surface of the soil and furnish food for stock may be used. On many soils it is impossible except at great cost to establish a good iurf, but there are few soils on which some sort of a pasture cannot be established. Old fields that are now given over to weeds and gullies may, with proper care, be converted into excellent pastures. Only perennial plants should be used to form a permanent pasture; annuals and biennials should be avoided. There are many perennial plants suitable for permanent pastures, but it would require too much space to attempt a list of them in this little book. The various plants best suited to different soils and climates can be determined only by actual test. The United States Government has established a number of grass gardens for the purpose of determining the most valuable forage plants for different soils and climates. There are a number of such gardens scattered about in this country, and from them we may learn much in regard to the various kinds of forage plants.

160. Temporary Pastures. - When a field is planted in some crop to furnish grazing for only a limited time, six months or a year for instance, it is called a temporary pasture. For such pastures almost any forage 
crop may be used; annuals or biennials serve the purpose as well as perennials.

The growing of pasture crops is the least exhausting method of cultivating soils. In the first place, all the manure from the grazing animals goes directly back to the soil. In the second place, the soil is well protected from washing, leaching, and surface evaporation. The only plant food lost to the soil is that which goes to build up the bodies of the pastured animals. There are fields known to have been used continuously for pasture for one hundred years or more that are to-day as good as ever.

Pastures should never be allowed to grow up in weeds. The weeds should be kept down by cutting before they ripen seed; or, if they become too numerous, the field should be plowed and planted for a time in some cultivated crop such as corn or tobacco.

\section{Questions}

1. Into what three classes can dry fodders be divided? 2. What is corn stover? 3. What is pulled fodder? 4. What is corn fodder? 5. What is the difference between corn stover and corn fodder? 6. What is straw? 7. For what is straw useful? 8. What is hay? 9. How does hay differ from the original green forage? 10. What per cent of moisture does average hay contain? 11. Name the two classes into which hays are divided. 12. Name a few of the best grasses for hay. 13. For how many years do most of the grasses used for hay live? 14. What leguminous crops are grown for hay? 15. How do the roots of legumes differ from those of the cereals and grasses? 16. Why are they better able to stand dry weather than the grasses? 17. Why is the cowpea a good crop for poor soils? 18. What 
is meant by a pasture? 19. What is permanent pasture? 20. What sort of crops must be planted to form a permanent pasture? 21. What is meant by a turf? 22. How does turf protect the soll? 23. What is meant by a grass garden? 24. What is a temporary pasture? 25. Why does not pasturing exhaust the soll? 
CHAPTER XXXI.-Root ANd Tuber Crops: Miscellaneous Crops

161. Root Crops.-The roots of several different kinds of crops furnish valuable food for animals. Turnips, beets, and carrots are all grown to feed animals; and as they develop late in the fall, they furnish fresh food during the winter months, when other fresh food is scarce. Radishes, parsnips and salsify are much grown in gardens, but are not used as food for stock. All of these root crops are biennials, and their large roots serve mainly as a storehouse from which the plant draws its seed-forming materials during the second season's growth. Root crops require great quantities of water for their growth; and for their proper development need a well cultivated, deep, loamy soil in which the soft roots may expand and reach their full size. The fresh leaves and tops of root crops contain large amounts of mineral matter which the plant has stored up to aid in forming seed the second season. For this reason the leaves and tops should always be returned to the soil; if they are not returned much valuable plant food is lost.

The soil in which root crops are growing should be kept free from weeds, and must be well supplied with available plant food, especially with phosphates.

162. Tuber Crops.-The two important tuber crops are the sweet and the Irish potato. The sweet potato is really a root crop, but instead of having one enlarged 
taproot it has clustered roots which are enlarged. The enlarged portions of the roots are called tuberous roots. Fig. 6 (page 40) shows the enlarged roots of the sweet potato. The enlarged portions are provided with small rootlets which draw food from the soil. The tubers of the Irish potato, on the other hand, are not true roots; they are the enlarged parts of underground stems. Fig. 23 shows the tuber of the Irish potato, and you will notice that the tubers, unlike the tuberous roots of the sweet potato, have no rootlets. Both of these erops are perennials; but since they are grown for their tubers a fresh crop must be planted each year, and as cultivated crops they are practically annuals. Sweet potatoes aro sometimes grown for

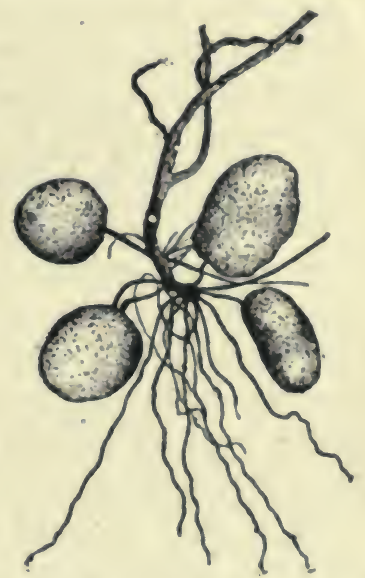

Fro. 28.-Tubers and roots of the Irish potato. (Original draw. ing from photograph.) cattle food, but Irish potatoes are used almost exclusirely for human food. The soil best suited to the sweet potato is a warm, well-drained, sandy loam. This crop will not do well in a heary or wet soil. The Irish potato requires for its best development richer soil than the sweet potato. For both crops the soil must be well drained and cultivated, and well supplied with moisture, though not wet. The sweet potato does best in a temperate or warm climate, and makes but 
a poor growth in a cold one. The Irish potato, on the other hand, does best in a cold climate, though it will grow well in the far South.

163. Tobacco.-Of the many crops grown on the farm besides those already described, we have space here to mention only a few, and among these tobacco is one of the more important.

Tobacco, which is an annual, can be grown in North America all the way from the equator to the southern part of Canada, and in many kinds of soil. This great diversity of soil and climate produces a number of varieties of tobacco, though the soil seems to have more influence on the variety of tobacco than the climate. Light sandy soils, as a rule, produce a small brightcolored leaf that is much esteemed for smoking tobacco. The heavier clay soils produce a large and darker leaf which is used for chewing tobacco and snuff. To produce a successful crop of tobacco the soil must be thoroughly cultivated and kept free from weeds, and the crop must be well supplied with available plant food. Because of the large amount of plant food it contains, and the clean method of cultivation necessary, tobacco is an exhausting crop to the soil. It should not be grown year after year on the same soil, but should be rotated with other crops, as will be described in the next chapter.

164. Cotton.-This is a distinctly Southern crop and cannot be grown profitably north of the southern parts of Virginia and Kentucky. Cotton is a very exhausting crop on the soil because of the way it is cultivated, and because, after the crop is gath- 
ered, the soil is left bare to the action of the weather. When the cottonseed or an equiralent amount of cottonseed-meal is returned to the soil as manure, the crop itself does not rapidly exhaust the supply of plant food in the soil. The lint or fibre of cotton contains such a small amount of plant food that many crops may be removed from the soil before it becomes exhausted. Cotton lint is almost pure cellulose, and contains very little ash. Three hundred pounds of lint cotton, considered a fair crop to the acre, contain about 1 pound of nitrogen, $\frac{1}{3}$ pound of phosphoric acid, and 21 pounds of potash. If the cotton crop removed plant food at this rate it would take a long time to impoverish a soil. But 300 pounds of lint take along with them 650 pounds of seed which contain about 20 pounds of nitrogen, 63 pounds of phosphoric acid, and $\tau_{\frac{2}{3}}$ pounds of potash. The lint and seed together remove from the soil considerable amounts of plant food which must be replaced else the soil will become poor. Cotton lands are much exposed to the weather during the winter months, and it is from this exposure rather than from any demands of the crop that they become exhausted. Land should not be cropped continuously in cotton year after year, but several crops should be rotated.

165. Garden and Fruit Crops.-These crops are of such great variety, and grow in so many different soils and climates that it would require too much space even to attempt to name the best known varieties of either fruits or vegetables.

As a rule garden and small fruit crops require warm, 
rich soils well supplied with organic matter, wood's mold being frequently used for the purpose. Warm soils enable the crops to get an. early start in the spring and so produce an early harvest.

\section{Questions}

1. Name three root crops grown for stock food. 2. Name three other root crops grown for vegetables. 3. Are these crops annuals, biennials or perennials? 4. How does the enlarged root benefit the growth of the plant? 5. What kind of soil do root crops require? 6. What kind of matter do the leaves and tops of these plants contain? 7. Name the two most important tuber crops. 8. Describe the roots of the sweet potato. 9. How do they differ from the root crops already mentioned? 10. What are the tubers of the Irish potato? 11. Are these crops annuals, biennials or perennials? 12. What kind of soil is best adapted to the sweet potato? 13. May good crops of either sweet or Irish potatoes be grown in a wet soil? 14. In what parts of this cointry does tobacco grow? 15. How are the different varieties of tobacco produced? 16. Why does the tobacco crop exhaust the soil? 17. In what part of the country does cotton grow? 18. Why is it that cotton lands soon become exhausted? 19. What kinds of soil are best suited for. garden crops and small fruit? 


\section{CHAPTER XXXII.-ROTATION OF CROPS}

166. What is Meant by Rotation.-Rotation means changing annually the kind of crop grown upon a given soil, the change being usually made in a regular order. For instance, from a certain field a crop of tobacco is grown; the next season the same field is planted in wheat, and the next in clover; the year after the clover, tobacco may be again grown, then wheat, and after the wheat clover again. Thus a rotation of these crops is practiced, but four or even more crops may be used in a rotation. In general farming rotation is much practiced, but in special farming it is unfortunately seldom used.

167. Benefits of Rotation.-Rotation of crops when properly practiced may be of benefit to the soil in many ways:

1. The way in which soils are cultivated varies with different crops. Tobacco and cotton for instance leave the soil quite bare; wheat and oats leave a thick stubble and large crops of weeds spring up as soon as they are gathered. If tobacco or cotton be grown continuously on one field, the soil suffers from washing and leaching. Tobacco and cotton should be rotated with crops that protect the soil, such as wheat and oats.

2. Many crops have shallow roots which draw most of their food from the upper soil. If such crops are grown continuously on a field, the upper soil becomes exhausted while the lower soil is untouched. Crops 
with shallow growing roots should be rotated with crops that have deep roots. Deep-growing roots draw much food from the subsoil.

3. Some crops require specially large, amounts of some particular plant food. Thus tobacco requires about ten times as much potash as phosphoric acid, and if such a crop be grown continuously upon a soil the potash becomes exhausted before the phosphoric acid. Tobacco should be rotated with some crop that requires large amounts of phosphates-wheat, for instance.

4. From the growth of some crops the soil becomes infested with weeds. Thus daises or wild carrots may become very numerous in a pasture or hayfield. When weeds become too numerous the field should be planted in some cleanly cultivated crop, such as corn, tobacco, or cotton.

5. Many crops have special insect enemies that feed upon them. Thus tobacco has the tobacco worm, wheat the Hessian fly, potatoes the potato beetle, and almost every crop grown has its special enemies among the thousands of insects found on the farm. If the same crop be grown upon a field year after year, these insect enemies increase, for they are suppliei with just the food they require. If, however, the kind of crop be changed, the insects suffer. A tobaceo worm hatched in a wheat field finds nothing to feed on, and a potato beetle starves in a tobacco patch.

6. Most crops are subject to attacks of some special disease which may not affect other crops. Wheat suffers from a disease called rust, but tobacco is not 
affected by it. Corn suffers from smut, but tobaceo does not. These plant diseases spread much as diseases spread among human beings and animals. Thus persons occupying a room previously occupied by a man suffering with a contagious disease like smallpox or scarlet fever are liable to contract the disease. The room is said to be infected by the disense, and in a similar way soils become infected by plant diseases. Wheat, for instance, when grown on a soil which the year before produced a crop of wheat affected by rust, is liable to contract the disease. But if some other crop is planted which is not liable to this disease there is no danger. A proper rotation of crops, for the reasons stated, checks the spread of plant diseases.

168. Examples of Rotation.-The crops used in rotation must, of course, be determined by the kind of crops it is desired to grow. The following examples have been found satisfactory:

Rotation 1.-First year tobacco, second year wheat, third year wheat, fourth and fifth years clover.

Rotation 2.-First year corn, second year oats, third year wheat, fourth and fifth years elover.

Rotation 3.-First year tobacco, second year wheat, third and fourth years clover.

Rotation 4.-First year corn, second year wheat, third and fourth years clover.

Rotation 5.-First year cotton, second year wheat, third and fourth years clover.

In rotations cowpeas or any other suitable leguminous crop may be used in place of clover. 
This simple diagram serves to illustrate a common rotation which is usually called the four-shift system:

\begin{tabular}{|c|c|c|c|c|}
\hline 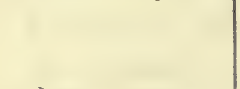 & $\begin{array}{l}\text { First } \\
\text { Field. }\end{array}$ & $\begin{array}{l}\text { Second } \\
\text { Field. }\end{array}$ & $\begin{array}{l}\text { Third } \\
\text { Field. }\end{array}$ & $\begin{array}{c}\text { Fourth } \\
\text { Field. }\end{array}$ \\
\hline $\begin{array}{l}\text { First year....... } \\
\text { Second year..... } \\
\text { Third year..... } \\
\text { Fourth year... }\end{array}$ & $\begin{array}{l}\text { Corn. } \\
\text { Wheat. } \\
\text { Clover. } \\
\text { Clover. }\end{array}$ & $\begin{array}{l}\text { Wheat. } \\
\text { Clover. } \\
\text { Clover. } \\
\text { Corn. }\end{array}$ & $\begin{array}{l}\text { Clover. } \\
\text { Clover. } \\
\text { Corn. } \\
\text { Wheat. }\end{array}$ & $\begin{array}{l}\text { Clover. } \\
\text { Corn. } \\
\text { Wheat. } \\
\text { Clover. }\end{array}$ \\
\hline
\end{tabular}

\section{Questions}

1. What is meant by a rotation of crops? 2. Give an example of rotation. 3. In what kind of farming is rotation of crops much practiced? 4. Clean cultivation exposes the soil to. what danger? 5. How does rotation lessen the danger arising from clean cultivation? 6. Why is it best to grcw a crop with deep-growing roots after a crop with shallow roots? 7. When one crop is grown continuously, is the drain upon the soil's supply of plant food uniform? 8. How is this irregularity corrected by rotation? 9. How does rotation check the spread of weeds? 10. How does rotation check the spread of injurious insects? How does rotation check plant diseases? 11. Is rotation of crops practiced in your neighborhood? 12. Give a few examples of rotation.

\section{PROBLEM}

Make a diagram showing a five-shift rotation consisting of corn, oats, wheat; and two years clover. 
UNIVERSITY

CALIFORNI COMPOSITION OF ANIMALS

\section{PART VI.-Anmal Pronuotion}

\section{CHAPTER XXXIII.-Composition of Animals.}

169. Stock Farming.-Farm crops are either sold direct from the farm, or else turned into animals or animal products, which are sold. The latter practice is called STOCK FARMING, only such crops being grown as are needed to feed the animals. This is the highest order of farming, as it requires not only a knowledge of how to grow erops, but of how to breel and feed animals. The stock farmer is both a grower of crops and a manufacturer of flesh. There are many kinds of stock farms; for instance there are cattle farms, sheep farms, goat farms, horse farms, poultry farms, and dairy farms, all run for the production of animals. Almost every farmer is more or less a stock raiser, for some animals must be kept on every farm to help with the farm work. It is important that all farmers should know how to feed and care for animals, and for stock farmers such knowledge is absolutely necessary. In order to feed animals to the best advantage it is well to know something of the animal's body and how it is built up.

170. Composition of Animal Bodies.-Bones and flesh make up a large part of the bodies of animals; the bones serve as a sort of framework which the flesh binds together. Through the flesh run the nerves and blood ressels-reins and arteries; and, protected by the 
flesh and bones, are found the vital organs-the brain, the heart, lungs, digestive organs, etc. Covering the body is the skin, which is in turn often covered by hair or feathers. The limbs are provided with hoofs or claws, and from the heads of many animals grow horns. These various parts of the animal bodies, which are so different in appearance, are quite different in composition, though they all contain certain substances in common.

171. Moisture.-All parts of the animal body contain moisture; even the apparently dry bones contain some moisture, and some parts of the body contain large quantities of water. Young animals, like young plants, contain more moisture than they do when they grow older. When the flesh of animals is dried out it forms cured meat. Most of us are familiar with the dried beef which is sold on the market as "chip-beef." This process of curing meat is similar to curing grass for hay; in both cases most of the moisture is driven off. The flesh of most animals usually contains from 40 to 60 per cent of water, seldom more than 60 per cent. The bones of course contain less moisture than the flesh, and the blood contains much more. The bodies of most domestic animals contain about 50 per cent of water, not counting the contents of the stomach. That part of the animal body which remains after the water is driven off is called dry matter.

172. Dry Matter.-When the dry matter of animal bodies is burned the greater part disappears into the air as gas and smoke, leaving behind a small quantity of ash. The part disappearing into the air is called 
organic matter or volatile matter, and the part remaining as ash is called inorganic matter, mineral matter, or ash.

173. Organic Matter.-The organic, or volatile matter, of animal bodies may be divided into two classes of compounds, one class containing nitrogen, and the other containing no nitrogen. Just as in the case of plants, the nitrogen-containing compounds are called protein, and the compounds containing no nitrogen are called non-nitrogenous substances. These compounds are, however, quite different in appearance from those found in plants, though they are made up of the same elements. The relative proportions of these two classes of substances are quite different in animal bodies from what they are in plants. In nearly all plants there are more of non-nitrogenous compounds than of nitrogenous; but in animals the reverse is true. The animal body contains as a rule more nitrogenous substances than non-nitrogenous.

174. Nitrogenous Substances: Protein.-The dry matter of the muscles, nerves, and tendons of animal bodies is made up almost entirely of nitrogen compounds. 'The hoofs, horns, claws, skin, blood, hair, and bones contain considerable amounts of nitrogen. The greater part of the bodies of animals is made up of compounds of nitrogen, though of course the different parts of the body contain different amounts. 'The bones and skin, for instance, contain less nitrogen than the flesh. 'These nitrogen compounds of animal bodies are made up of exactly the same elements that make up those of plants; namely, carbon, oxygen, hydrogen, 
nitrogen, sulphur, and a litttle phosphorus. But though they are made up of the same elements, they are different compounds, and differ in appearance and in the proportions in which the elements are combined. The nitrogen compounds are by far the most important compounds of the animal body.

175. Non-Nitrogenous Substances.-The non-nitrogenous matter of plants is made up principally of starch, sugar, gum, and woody matter, usually with small quantities of oil or fat. In animal bodies, on the other hand, nearly all of this matter is fat or oil. No starch or woody matter is found in animal bodies, and only a little sugar.

The amount of fat in animal bodies varies greatly. Different animals contain very different amounts of fat, and the same body varies from day to day in the amount of fat it contains. The non-nitrogenous matter of animal bodies is made up of the same elements as the non-nitrogenous matter of plants; namely, carbon, hydrogen, and oxygen. These elements are, however, combined in a different way, and the fats of animal bodies are different in appearance from the fats of plants. Thus lard is quite a different thing from cottonseed oil, though they both contain the same elements.

176. Mineral Matter, or Ash.-Most of the mineral matter of animal bodies is contained in the bones, and only small quantities are found in the flesh and blood. Older animals as a rule contain more ash than younger animals. This is because their bones are larger and better developed. As a large part of the bones of all 
animals is made up of phosphates, the ash of animal bodies consists largely of phosphate. Ash makes up about 2 to 5 per cent of animal bodies. The ash of animal bodies contains small quantities of most of the elements found in the ashes of plants. The phosphates make up about 80 per cent of the ash.

\section{Questions}

1. What is meant by stock farming? 2. Name some of the various kinds of stock farms. 3. Name some of the principal substances that make up animal bodies. 4. In what does the process of curing meat resemble that of curing hay? 5. As a rule, do animal bodies contain as much moisture as plants? 6. What two classes of compounds make up the dry matter of animal bodies? 7. Divide the organic matter into two classes of substances. 8. What part of the flesh is made up largely of protein? 9. In what other parts of the body is protein found? 10. As a rule, which contain the more protein, animal bodies or plants? 11. What elements make up protein? 12. What substance makes up most of the non-nitrogenous matter of animal bodies? 13. Is starch or woody matter found in animal bodies? 14. In what part of animal bodies is most of the mineral matter found? 
CHAPTER XXXIV.-Food, Work, AND GROWTH of Animals

\section{Animals and Plants are Alike in Composition.-} In the last chapter we learned that in composition animal bodies closely resemble plants. This is not surprising when we consider the fact that the food of animals consists principally of plants. It is true that some animals are carnivorous, that is, they live on the flesh of other animals, but the animals so used for food derive their food from plants.

178. Plants Manufacture Food for Animals.-While plants and animals are much alike in composition they differ very much in their manner of taking in food and growing. Plants as a rule take up the necessary raw materials from the earth and air, and change them into the compounds which make up their supply of protein, carbohydrates, fats, etc. Animals as a rule have not this power of taking the raw materials into their bodies and changing them into other compounds. A horse or cow will starve on the food that supplies plants, even though this food contains all the elements found in the animal's body. The raw materials of the earth and air must first be made into plants before they are fit food for animals. Plants are the makers of animal food.

179. All Living Animals are Constantly Growing.The growth of young animals is generally rapid; they increase in size till they reach the point where they 
apparently cease to grow, but in reality they go on growing, though their size remains about constant. They are continually repairing and rebuilding the worn places in their bodies; twice ench year a new crop of hair is grown, the various muscles are constantly renewed, and in this way the body is continually growing. These repairs and changes cease only when the animal dies. Life means change and constant repairing; an addition of new growth and a replacing of old parts by new. In plants these changes usually mean the addition of new growth, most plants continuing to increase in size so long as they live. Most animals, on the other hand, reach a fixed point where they cease to grow in size, and such changes in the bodies as take place consist in renewing worn parts.

180. Food Necessary for Growth.-To effect the changes that are constantly taking place in the animal body a constant supply of the proper kinds of food is necessary. Not only is food necessary for the repairs that are constantly going on, but it is necessary to keep up the temperature of the body. If the temperature of an animal's body is much reduced, a chill is the result and sickness usually follows. Food and a proper supply of fresh air are necessary to prevent the cooling off of the animal body.

181. Food Necessary for Work.-Food and air are also necessary to enable the animal to use its muscles in moving about. The animal body has often been compared to a steam engine. Feed an engine fuel, water, and air, and it does work; take away its supply of any one of these three things, it ceases to move, and 
is said to be dead. The animal body requires food, water, and air, and when supplied with them it can move about and do work. Take away any one of them, and the body soon becomes unable to move, and dies.

182. How to Feed Animals.-The art of feeding animals is knowing how to supply them with the proper amounts and kinds of food. Different kinds of animals of course require different amounts of food. A cow or a steer can eat at one time much more food than a horse, and a horse can eat more than a sheep. Then, too, the same kind of animal under different conditions requires different amounts of food. A working horse. requires more and better food than a horse that is doing nothing. A cow giving milk requires more food than a dry cow. To grow and feed animals successfully, all these things must be considered. In feeding stock one thing that should especially be considered is the fact that scrubby animals eat just as much as fine, well-bred stock. A cow giving 2 or 3 quarts of milk a day will eat just about as much as a cow giving two gallons. A cow giving an average of 3 quarts of milk a day will produce in six months about 137 gallons, which at 20 cents a gallon would be worth just $\$ 2 \% .40$. A cow giving an average of 2 gallons of milk a day will produce in the same length of time 365 gallons, which at 20 cents would be worth $\$ 73.00$. The food of each is about equal in cost, yet the milk produced by the better cow is worth $\$ 45.60$ more than the milk produced by the scrub. The scrub costs as much to feed as the good cow and does less than half the work; she is, therefore. more than twice as expensive to keep. A 
FOOD, WORK, AND GROWTH OF ANMCALS 189

little half-grown "runt" of a horse may eat nearly as much as a fine powerful draft horse, and yet not be able to do half the work. It is, therefore, just about twice as expensive to keep. The poorer the class of stock the more expensive it is to keep.

\section{Questions}

1. The food of most animals consists of what? 2. How do the foods of animals differ from the foods of plants? 3. How are the raw materials of the earth and atr converted into animal foods? 4. Do living animals ever cease to grow? 5. What changes are constantly going on in the bodies of animals? 6. To effect the changes in animal bodies what is necessary? 7. What is necessary to keep up the temperature of animal bodies? 8 . What three things are necessary to enable an animal to work? 9. Why is it more expensive to keep scrub stock than it is to keep more valuable animals?

\section{PROBLEM}

Let us suppose that we have to feed two milch cows, A and $B$. They both eat about the same amount of food and cost the same to keep. A, however, gives an average of 3 gallons of milk a day, whlle B gives only an average of 7 quarts. Milk is worth 20 cents a gallon. What is the approximate value of the milk produced in a month of 30 days by each cow? 


\section{CHAPTER XXXV.-Care of Animals}

183. Care as Important as Feeding.-In the last chapter you were told that the art of feeding is knowing how to supply the animal with the proper amounts and kinds of food. There are several ways of supplying the animal with food; it may be turned out to pasture, or it may be kept in the stable, and the food given it, but whatever the method adopted the animal should be well treated. If the animal is abused or neglected it will suffer, no matter how well the actual feeding is done. Good feeding does not consist simply in good food; it means good attention and kindness as well. If the animal is to be kept in a stable, the first care should be to provide a comfortable stable.

184. Stables.-Children and plants cannot develop without fresh air and sunshine; the same is true of domestic animals. To keep animals shut up in foul, dark, ill-rentilated stables and expect them to grow and do well is as foolish as attempting to grow wheat in a cellar. Yet how many animals are provided with comfortable stables? Once a year is usually considered often enough to clean a stable. The air is nearly always saturated with the odor of decaying organic matter. The light of day seldom penetrates its foul interior, and here the poor animals must spend a large part of their lives. Is it any wonder that so many cattle suffer from consumption, and through their flesh and milk transmit this fatal disease to man? All ani- 
mals are cleanly in their habits, and there are few domestic animals that would of their own accord live in the foul stables often provided for their use by thoughtless owners. There is a popular belief that a man's character may be judged by the way he treats his beasts. Let us hope that this is not altogether true, for it is terrible to think that the stock owners of this country are possessed of characters as foul as the stables they provide for their animals.

All stables should if possible be well lighted and ventilated, and should always be kept clean. Each day fresh bedding should be provided for the animal, no matter whether the old bedding is thrown out or retained. The floor of the stable should be kept as dry as possible.

185. Kindness to Animals.-Kindness is necessary to the successful feeding of domestic animals. Domestic animals that are well treated are nearly always gentle, and easily handled and fed. They enjoy their food, and hy their improved condition and good behavior more than repay the kindness shown them. On the other hand, ill treatment almost invariably causes the animals to lose flesh. From blows and abuse they become irritable, often vicions, and diffieult to manage. The nervous worry caused by ill treatment brings on indigestion, and loss of flesh results. The man who illtreats his animals pays for it out of his own pocket. Not only does he lose the respect of all right-minded people, but he actually loses money because of the decrease in value of his stock. It is an invariable rule that animals under kind treatment can do more work 
than when abused. Systematic beating or abuse decreases the value of an animal many dollars. The utterly senseless and cruel practice of using checkreins to force horses to hold up their heads in an unnatural position cannot be too strongly condemned. The checkrein should be banished from all well-regulated farms.

186. Treatment of Cows.-The cow is very sensitive to ill treatment. One of the dairy experts of this country, after a careful study of milch cows, says: "The elaboration [formation] of milk does not proceed at a uniform rate from milking to milking, but is most active at the time of milking, and is dependent not only upon the stimulus which the milk glands derive from the manipulation of the teats and udder, but upon the nerrous condition of the animal at the time of milking.

"In consequence of this, slight changes in the condition under which the milking is done may have a decided influence upon both the yield and quality of the milk." He says further: "It is my opinion that kind treatment and pleasant surroundings will have a greater influence upon the quality of milk than the kind of food, provided the rations given contain sufficient nutrients for the maintenance of the animal."*

187. Regularity and System.-All animals should be fed and watered regularly, and it is very important that cows should be milked at regular intervals. Most animals form habits quickly, and soon learn when to

* Professor Babcock in the Wisconsin Station Report for 1899. 
expect their food and exereise. Changing suddenly the time and manner of feeding disturbs the animals, making them restless and uneasy. Changing the time or manner of milking often has a bad effect on the quantity or quality of milk.

188. Exercise and Air.-All animals confined in stables should be given a certain amount of daily exercise and fresh air. Fattening eattle require but little exercise, but they need fresh air and sunshine. Milch cows do best when they have a few hours in which to walk about and exercise their muscles. Animals confined in close stalls have little opportunity to keep their skins clean by licking themselves. The habit animals have of licking their skins is as important to them as bathing is to human beings. When they cannot lick themselves they suffer as much or more than people who have no opportunity of washing their skins. Brushing the animals each day may partially take the place of their lieking.

189. Exposure to the Weather-Many persons appear to have the idea that domestic animals can endure without injury any amount of exposure to the weather. Horses that have become very warm from much exercise are left to cool off in the eoldest weather with no more protection than their own moist skins. Cattle of all kinds and ages are left out to face the coldest blizzards, or are kept in draughty stables. Many animals can endure exposure of this kind, just as some persons of strong constitution can survive exposure that would kill most people, but the number of animals that die each year from exposure to the weather is 13 
very large, and many, while not killed outright, are much weakened and thus made liable to disease. To obtain the best results from feeding, the animal must be provided with some protection from the extremes of heat and cold.

\section{Questions}

1. In what does the art of feeding consist? 2. What is necessary besides good food to secure success in feeding animals? 3. In what kind of stables should animals be kept? 4. Why? 5. What effect does kind treatment have on most animals? 6. What effect does abuse have on the value of an animal? 7. How does the treatment of the cow affect the amount and quality of the milk? 8. Why is it best to feed and attend animals with regularity and system? 9. What is a cow's substitute for a bath? 10. Why should animals be protected from the weather? 


\section{CHAPTER XXXVI.-FeEding of ANimals}

190. Methods of Feeding.-As alregdy stated, there are several methods of feeding domestic animals. The animal may be turned out to find its own living from the plants growing naturally in the soil. This method of feeding is known as PASTuRing. Sometimes the animals turned out to pasture are supplied in winter or in very dry weather with extra amounts of food in the shape of hay, straw, grain, etc. Another method of feeding is to keep the animals in a stable and supply them food at regular intervals; this is known as STALLFEEDING, and is much practiced. The art of feeding has to do mainly with stall-feeding, for when the animal is at pasture it, as a rule; finds its own food. Now, in either method of feeding, the first thing to be looked after is water.

191. Water for Animals.-Domestic animals should always be furnished an abundant supply of fresh, pure water. Most farms are well supplied with good water, but, unfortunately, the supply provided for animals is not always good. The stagnant water of ponds, and the water of polluted streams is often considered good enough for their use. All domestic animals prefer pure water, and if they drink dirty water it is only because they can get no better. Impure water is often the beginning of disease in animals, and from them it may pass to human beings. The milk from cows supplied with impure water often causes outbreaks 
of disease among human beings. The dairyman cannot be too careful about the water he provides for his cows.

192. Pasturing.-Herbivorous or plant-eating animals in their native state make their living off the plants growing naturally in the soil, and many domestic animals are fed in this way. For a part of the year at least they are turned out to find their own living from the grass and other plants which form their food. This is the method generally practiced for raising animals that are to serve as food for man. In raising cattle for market, the object is to produce the greatest weight of flesh at the least possible cost. Where the soil will grow grasses suitable for pasture, large tracts of land are planted in grass, which furnishes a good living to the cattle grazing it. The labor and cost of feeding is in this way greatly reduced, and the profits resulting from the sale of the cattle correspondingly increased. The bluegrass regions of the Eastern States, and the great prairie regions of the West, supply pasture for many herds of cattle. Sheep can make their living on rougher and poorer fare than cattle, and the mountains, while often too poor to support cattle, will furnish excellent pasture for sheep.

- Even the best of pastures, however, can supply but a scant living for domestic animals in winter, and during this season of cold other food in some shape should be provided for them.- During cold weather animals require a constant supply of proper food to keep them warm If not fed regularly, their store of fat is all used up to maintain the proper body temperature, and they become thin and weak, and unable 
to withstand the attacks of disease. A regular supply of food better enables animals to endure the cold and withstand sudden changes of temperature. An animal irregularly supplied with food is poorly prepared to meet the sudden changes in our climate. In a halfstarved condition it may be subjected to the cold of a blizzard, and suffer more in consequence than a wellfed animal. To obtain healthy, well-grown animals of any kind, a constant supply of good food is necessary. Animals may either be left out all the year, and during the winter have extra food supplied them, or they may be stabled and fed in stalls. If left in the pasture, some sort of rough shelter should be provided as a protection against the coldest weather. We shall consider the subject of stall-feeding in the following chapters.

\section{Questions}

1. Name several methods of feeding domestic animals. 2. Why is it important to supply domestic animals with pure water? 3. What constitutes the food of herbivorous animals? 4. What is meant by pasturing animals? 5. In ralsing cattle for market what is the prime object? 6. Name a part of this country where large herds of cattle are ralsed. 7. What class of stock can make their living on a poorer pasture than cattle? 8 . Why should animals be supplied with extra food during the winter? 


\section{CHAPTER XXXVII.-STOCK FooD}

\section{Need for Fixing the Amounts of Food Supplied} Animals.-In stall-feeding the animal must be supplied with the proper amounts of food to keep it in good condition. How are we to know just how much food different animals require to keep them in condition? We may guess at the proper amounts, or we may feed the animal till it will eat no more, but both of these methods are liable to cause mistakes. Animals are greedy, and, if allowed, will often eat more than is good for them. So it is best to know. just how much food to give them. Now there is a method of determining how much food different animals require to keep them in condition. Let us see what it is.

194. Digestion.-Plants from the elements of earth, air, and water build up the compounds that go to form them. Animals build up their bodies from the compounds formed by the plants. The compounds of the plants are made over in the animal body into other compounds, and the process is called DIgestion. The process of digestion is a very complicated one, and is not thoroughly understood; so wé need not consider it just now. It is enough for our purpose to know that animals in building up their bodies use the compounds formed by plants. These foods are taken into the animal's stomach where portions of the different compounds are digested, which means that they become 
part of the animal's body. The undigested portion is passed off as manure.

\section{Protein, Non-Nitrogenous Matter, and Mineral} Matter All Necessary Foods.-The nitrogen compounds of animal bodies are built up only from the nitrogen compounds of plants. The non-nitrogenous matters of animal bodies are built up principally from the non-nitrogenous matters of plants, though they may also be formed from the nitrogen compounds. The mineral matter of animal bodies comes largely from the mineral matter of plants. Animals, then, in order to keep their bodies built up, must be supplied with food containing protein, non-nitrogenous matter, and mineral matter. The amount of mineral matter required in animal bodies is so small that there is always enough in the ordinary supply of food. It is not necessary to consider mineral matter as a food. Salt is not considered a food, but merely a relish. Protein and non-nitrogenous matter are then the only solid substances we need consider in selecting food for animals. Protein builds up the muscles, nerves, blood, bones, and all the nitrogen-containing parts of the body. It may also help to form fat and keep the body warm. Protein compounds may serve to build up every part of the animal body, and animals may live on a food made up exclusively of protein. But such a diet is not good for the health of most domestic animals. Nonnitrogenous matters cannot build up the nitrogen compounds of animal bodies, and animals starve to death on a diet of non-nitrogenous matter alone. But certain amounts of non-nitrogenous matters are necessary for 
the health of the animal, and all animal food should contain some of these compounds.

196. Composition of Foods.-We have already learned that plants are made up of water and dry matter, and that the dry matter is made up of mineral matter, protein, and non-nitrogenous matter. In order to determine the value of plants for cattle foods, the amounts of the different substances they contain have been determined. In determining the amounts of the compounds; the plant is analyzed, which means that it is broken up into some of the substances that form it. When cattle foods are analyzed, they are divided up into six classes of substances as follows:

1. Water is determined by drying in an oven a weighed portion of the finely ground substance until it is perfectly dry. The dried portion is then weighed, and the loss in weight gives the amount of water, or MOISTURE as it is often called.

2. Ash is determined by burning at a low heat a weighed portion of the ground substance. The weight of the ashes gives the anıunt of mineral matter or ash, usually called CRUDE AŚH.

3. Nitrogen is determined by a process that is too complicated for us to describe here, but which is known to be accurate. Protein is known to contain about 16 per cent of nitrogen, so if we multiply the nitrogen found by $6 \frac{1}{4}$ we get the amount of protein in the substance. The protein is usually called CRUDE PROTEIN:

4. Fats and oils are dissolved from a weighed por- 
tion of the ground substance by means of ether." The ether is evaporated, and the fats and oil are weighed. The result is usually called CRUDE FAT.

5. The woody matter is determined in a portion of the ground-substance by dissolving out all the other compounds by boiling the sample, first with a solution of an acid, and then with an alkali. 'The woody matter is then washed, dried, weighed, burned, and the weight of ash subtracted. The result is CRUDE FIBER.

6. The per cent of moisture, crude ash, crude protein, crude fat, and crude fiber are all added together and the sum subtracted from 100 . The remainder represents what is called NITROGEN-FREF EXTRACT. Nitrogen-free extract is so ealled because it contains no nitrogen compounds. It is made up principally of starch, sugar, and gum, but includes everything in the plant except those substances already determined.

An analysis made in the manner just lescribed is called a PROXIMATE ANALYsis of a feeding stuff. It is called proximatc because all the compounds in the substance are not determined, but only those necessary to decide its value as a cattle food. The sum of the nutrients in a proximate analysis must always make 100.

Different cattle foods differ greatly in composition; some contain large amounts of protein, others of fat, and still others of starch. Even the same food, under different conditions, varies in composition. A great

\footnotetext{
- Ether is a liquid much used in medicine to produce insensibility to pain in operatlons. It dissolves fats and olls very easily, and evaporates very qulekly.
} 
many analyses have been made of the more important feeding stuffs, and the average of all the analyses of each food gives its average composition. Nearly everything that can be used as a cattle food has been analyzed, and the results recorded. In Table $\mathrm{V}$ of the Appendix are arranged the averages of a number of analyses of the more important feeding stuffs. These figures are intended to show what these different foods contain under average conditions.

197. Nutrients.-The various compounds in plants that are useful for building up the animal body are called NUTRIENTS, because they nourish the animal body. The nutrients of plants are protein, and nonnitrogenous matters; the non-nitrogenous matters being divided into fat, nitrogen-free extract, and fiber.

\section{Questions}

1. Why is it best to know exastly how much food stallfed animals require to keep them in good condition? 2. How do animals build up their bodies? 3. What becomes of the food the animal takes into its body in eating? 4 . The change that food undergoes in the animal's body is called what? 5. How are the nitrogen compounds in animal bodies built up? 6. How is the non-nitrogenous matter of animal bodies built up? 7. Can the non-nitrogenous matters of plants build up nitrogen compounds in animal bodies? 8. Can the nitrogen compounds of plants build up the nonnitrogenous matters in animal bodies? 9. What is meant by an analysis of a food? 10. How is the amount of water determined in a food? 11. How is ash determined? 12. How is protein determined from nitrogen? 13. How is fat determined? 14. How is woody matter determined? 15. What is meant by nitrogen-free extract, and how is it determined? 16. What is a proximate analysis? 17. What are nutrients? 


\section{PROBLEM}

Suppose a sample of hay contains 9.77 per cent of water, 8.99 per cent of protein, 1.75 per cent of fat, 31.05 per cent of fiber and 4.55 per cent of ash. How much nitrogen-free extract does the hay contain? 
CHAPTER XXXVIII.-Digestibility of Stock Foods

198. The Value of a Food Depends on Its Digastibility.-Only a part of the food eaten by animals is digested; the undigested portion is passed off as manure. Naturally, the portion digested is of much greater value to the animal body than the undigested portion. So in judging of the value of a cattle food, we must always take into consideration the digestibility of the nutrients contained in the food. Table $\mathrm{V}$ of the Appendix shows the results of a number of analyses of different foods, most of which are very different in composition. These foods also differ very much in the amounts of digestible nutrients they contain. Let us see how it is possible to determine the digestibility of the nutrients of cattle foods.

199. Digestion Experiment.--Of the food eaten by animals, a part is digested and retained in the body, and a part passed off as manure. Now, suppose we feed to an animal a weighed portion of food in which we have determined accurately the amounts of the various nutrients. If no other food has been given the animal, we can collect the manure resulting and in it determine the amounts of the nutrients undigested. The difference between the total nutrients in the food and the undigested nutrients in the manure will gire us the digestible nutrients. Suppose we select an ox and feed him 30 pounds of hay per day. The hay con- 
tains 6 per cent of protein. So we are supplying the os 1.8 pounds of protein per day. If the manure from the ox contain 3 per cent of protein, only one-half or 50 per cent of the protein of the hay is digestible. In the same way we may determine the digestibility of the other nutrients of the food. Such tests of foods as these are called DIGESTION EXPERIMENTS.

In making digestion experiments much eare and patience are required. For use in such tests only. healthy arerage animals should be selected, and for a few days before the beginning of the experiment the animal must be fed nothing but the food to be tested. In this time the manure resulting from any other food eaten previously by the animal is passed from the body.

Digestion experiments are usually continued for several days or even weeks, and during the time they are in progress the animal must be carefully looked after. Samples of the food to be tested must be carefully analyzed to determine the amounts of its nutrients; and at certain intervals the animal must be supplied with weighed quantities of the food. All the manure, both liquid and solid, passed by the animal during the experiment should be colleeted and weighed. Samples of the manure are analyzed in order to determine the amounts of the nutrients left in it; a number of samples being taken, each at a different stage of the experiment. The average amounts of the sutrients in the manure are subtracted from the arerage amounts of the same nutrients in the food, and the results show the amounts of digested nutrients. With figures determined in this way we may easily calculate the 
digestible nutrients in any given weight of food. For instance, from the composition of timothy hay shown in Table $\mathrm{V}$ in the Appendix we learn that every 100 pounds of such hay contains 5.9 pounds of protein, 2.5 pounds of fat, 45 pounds of nitrogen-free extract, and 29 pounds of fiber. Digestion experiments show that 48 per cent of the protein, 57 per cent of the fat, 63 per cent of the nitrogen-free extract, and 52 per cent of the fiber are digestible. Then every hundred pounds of timothy hay must, according to these figures, contain the following amounts of digestible nutrients: 2.8 pounds of protein, 1.4 pounds of fat, 28.4 pounds of nitrogen-free extract and 15 pounds of fiber.

A great many digestion experiments have been made with many different kinds of animals and foods. Such tests are necessary, for different animals have different powers of digestion. A cow, for instance, may digest more of a certain kind of food than a horse, a growing calf may digest more of a food than an old steer. Different samples of the same food differ in the amounts of digestible nutrients they contain. It is only by making many tests, and taking their average that reliable figures can be obtained. The experiment stations of this and of other countries have made, and are making, many tests to determine the digestibility of all kinds of animal foods, and in Table VI of the Appendix will be found the averages of the most reliable of these tests for the foods shown in Table V. The figures giving the percentages of the nutrients digested are called DIGESTION COEFFICIENTS. With the figures in Tables $V$ and VI one may easily calculate 
the amounts of digestible nutrients in any of the foods there recorded. For the convenience of the student we have calculated the amounts of digestible nutrients in most of the foods shown in Table $\mathrm{V}$, and the results are arranged in Table VII. The nitrogen-free extract and crude fiber are combined in this table, and the sum is given under carbohydrates.

\section{Questions}

1. On what does the value of a cattle food chiefly depend? 2. In judging of the value of a cattle food what must be considered besides lis composition? 3. How may the amounts of digestible nutrients in a food be determined? 4. What are digestion coefficients?

\section{PROBLEMS}

1. Suppose we feed a horse 40 pounds of corn which contain 4 pounds of protein, and the manure resulting contains 1 pound of protein, what per cent of the protein is digestible? 2. Suppose a cow is fed 30 pounds of clover hay, which contain 3 pounds of protein, and the manure resulting contains .96 of a pound of protein, what per cent of the protein is digestible?

3. Suppose a steer is fed 30 pounds of ensilage containing 2 pounds of crude fiber, and the manure resuiting contains .76 of a pound of crude fiber, what per cent of the taber is digestible? 


\section{CHAPTER XXXIX.-Calculating Rations fOR Animals}

200. Rations.-The food supplied an animal during any stated period is called a RATION; thus the food of one day is called a day's ration. Calculating the different amounts of the food to be ircluded in a ration is called compounding Rations. The compounding of rations means the mixing of the proper amounts of digestible nutrients to keep the animal in good condition.

201. Feeding Tests.-Different animals require different amounts of digestible nutrients, and the same animal under different conditions requires different amounts. After a long walk we usually come home hungry; we need food to renew the portions of our body worn by the exercise of walking. The question is how much food is needed. We usually settle the question by eating till we are no longer hungry, and by this method eat too much, and make ourselves sick. Animals, too, if allowed the opportunity will often make themselves sick by orereating. Allow a horse to help himself from an oat or corn bin, and he will eat till he can hold no more; this usually resulis in a case of colic. To keep stall-fed animals in good condition, they must be supplied with the proper amounts of nutrients, and no more. To overfeed an animal is as bad as to underfeed it. In order to determine how much food different animals require, a great many careful 
tests have been mads. Many different kinds of animals in various parts of the world have been fed weighed amounts of food, in samples of which the digestib).e nutrients had been previously determined. In this manner the weights of digestible protein and nonnitrogenous matters neessary to keep the animal in good condition are determined. Such figures are called bEEDING STANDARDS. In Table VIII of the Appendix the average results of many such tests are recorded.

202. Nutritive Ratio.-The last column, Table VIII, shows nutritive ratios. By NUTRITIVE R.ATIO is meant the proportion of digestible protein to fat, nitrogen-free extract and fiber combined. To calculate the ratio we must start by multiplying the fat by 2.4; for the fat is considered nearly $2 \frac{1}{2}$ times as raluable for food as the carbohydrates (nitrogen-free extract and crude fiber). Let us talie as an example the corn fodder shown at the beginning of Table VII. We have $t$ of a pound of fat $\times 2.4=.96+11.6$ carbohydrates $=12.56 \div 1$ of protein $=12.56$, giving a ratio of 1 to 12.56 , which means that the food contains 12.56 times as much carbohydrates and fat as protein. We have the follow ing formula:

\section{Fat $\times 24+$ carbohydrateg}

Protein

203. Compounding Rations.-Now let us see low the figures in Table VIII may be applied. Suppose we have a horse doing ordinary farm work, and we wish to supply him with the proper amount of food to enable him to do his work well and at the same time keep him in 
good condition. Our horse weighs between 950 and 1,000 pounds, and we have a supply of oats, shelled corn, and clover hay, with which to feed him. How can we mix these foods so as to supply him the proper amounts of protein, fat and carbohydrates? By referring to Table VIII we find that a horse at moderate work, for every thousand pounds of live weight requires each day 22 pounds of dry matter, containing of digestible nutrients, 1.8 pounds of protein, .6 of a pound of fat and 11 pounds of carbohydrates; giving a nutritive ratio of 1 to 6.9 . In mixing our foods to supply. this ratio we will start by taking 10 pounds of corn. Referring to Table VII we find that this amount of corn contains 8.9 pounds of dry matter, .8 of a pound of digestible protein, .46 of a pound of digestible fat, and 6.59 pounds of digestible carbohydrates. Nèxt we take 10 pounds of clover hay, which we find from the same table contains 8.47 pounds of dry matter; and of digestible nutrients, .76 of a pound of protein, .20 of a pound of fat, and 3.84 pounds of carbohydrates. Adding these figures together we have 17.4 pounds of dry matter, 1.6 pounds of protein, .66 of a pound of fat, and 10.4 pounds of carbohydrates. To complete our required ration we need only. 4.6 pounds of dry matter; therefore 10 pounds of oats would give more than is needed, so we will take 5 pounds. This amount of oats according to Table VII gives us 4.45 pounds of dry matter; and of digestible nutrients, .46 of a pound of protein, .21 of a pound of fat, and 2.36 pounds of carbohydrates. Adding these figures to those for hay and corn we have: 
Digestible Nutrient8.

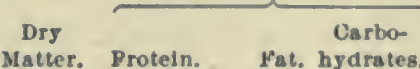

$\begin{array}{rrrrrr}10 & \text { pounds shelled corn } \ldots & 8.9 & .80 & .46 & 6.59 \\ 10 \text { pounds clover hay..... } & 8.5 & .76 & .20 & 3.84 \\ 5 \text { pounds oats } \ldots \ldots \ldots \ldots & 4.5 & .46 & .21 & 2.36 \\ \text { Compounded ration } \ldots \ldots \ldots & 21.9 & 2.02 & .87 & 12.79 \\ \text { Required ration } \ldots \ldots \ldots \ldots & 22.0 & 1.80 & .60 & 11.00\end{array}$

Nutritive ratio in compounded ration, 1 to 7.3 ; required ratio, 1 to 6.9 .

These rations agree well enough, so let us try another, say one for a cow giving milk. Table VIII shows that a cow giving milk, for every thousand pounds of weight requires per day 28 pounds of dry matter containing of digestible nutrients, 2.5 pounds protein, .5 pound fat, and 12 pounds carbohydrates. But suppose our cow weighs only 800 pounds. $\mathrm{Ve}$ should then take only.$S$ of the ration or 22.4 pounds dry matter, 2 pounds protein, .4 pound of fat, and 9.6 pounds carbohydrates. We have, to feed our cow, corn ensilage, cowpea hay, hay of mixed grasses, and wheat bran. As ensilage is a bulky food containing much water, let us start by taking 30 pounds of it, and as bran is a rich dry food, we should take much less of it, say 5 pounds. The amounts of these two foods together give us about 10 pounds of dry matter, leaving about 12 pounds to be supplied by the two hays. As ensilage contains but little protein let us take the larger amount of pea hay which is rich in protein. We will take say 8 pounds of the pea liay and 5 pounds of the mixed hay. Now referring to Table VII we find that the amounts of food selected give the following figures: 
Digestible Nutrients.

4

Dry

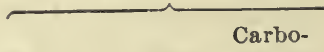

Matter. Protein. Fat. hydrates.

$\begin{array}{rlrrrr}30 \text { pounds of ensilage...... } & 6.27 & .27 & .21 & 3.39 \\ 5 \text { pounds of bran ........ } & 4.40 & .61 & .13 & 1.96 \\ 8 \text { pounds of pea hay...... } & 7.14 & .86 & .08 & 3.12 \\ 5 \text { pounds of mixed hay... } & 4.35 & .30 & .06 & 2.05 \\ \text { Compounded ration } \ldots \ldots \ldots & 22.16 & \frac{.30}{2.04} & .48 & 10.52 \\ \text { Required ration .......... } & 22.40 & 2.00 & .40 & 9.60\end{array}$

Nutritive ratio in compounded ration, 1 to 5.7; required ratio, 1 to 5.3 .

It is not necessary that the calculated ration should agree exactly with the standard. The agreement between the standard and the two examples given is close enough for all practical purposes. The standards in Table VIII are intended merely as guides in mixing rations, not as fixed rules by which we must work. In calculating rations, find the amounts of digestible nutrients in the principal food to be used, and try combining with these figures those for varying amounts of the other foods till a ration is obtained giving a nutritive ratio as near as possible to the standard. It is not necessary to use fractions of pounds in weighing the different foods:

204. Weighing the Different Foods in the Ration.It would of course require. far too much labor to weigh out the different foods each time an animal is fed, and such care is not necessary. Grains, meals, bran, and other similar foods may be measured, and the weight of a given measure determined. Ensilage may also be measured, and so may root crops. For hay and other fodders the weights of the fodder held on a certain 
fork or in a hamper should be determined once for all. With this knowledge the weight of fodder may be closely estimated without actual weighing at each feeding.

\section{Questions}

1. What is meant by a ration? 2. What is meant by nutritive ratio? 3. What are feeding standards? 4. How are feeding standards determined?

\section{PROBIEMS}

1. We wish to mix a ration for a fattening ox weighing 1,000 pounds, and for food have decided to use 30 pounds corn ensllage, 5 pounds cottonseed-meal and 5 pounds mixed hay. How much wheat straw must be added to complete the ration?

2. Suppose we have a herd of wool-growing sheep and wish to feed them during the winter. Our sheep weigh about 130 pounds each, so that eight sheep weigh about 1,000 pounds. The food we have to give them consists of shelled corn and mixed hay. Calculate the amount of each food necessary to supply the proper ration.

3. Calculate the nutritive ratio in a ration supplying 2.3 pounds of protein, .88 pound lat and 14 pounds carbohydrates. 


\section{CHAPTER XI.-Selecting Stock Foods}

\section{Different Animals Require Different Foods:-} The art of stock feeding does not consist simply in mixing certain proportions of digestible nutrients. The ration may contain the proper proportions of digestible nutrients, and yet be unfit for food. The taste of the animal fed must be considered. Different kinds of animals differ in their tastes for foods much as human beings do. The cow eats readily food that a horse will not touch, and the pig eats food that would be refused by either the cow or horse. The art of stock feeding consịsts in supplying animals not only the proper amounts of food, but also the proper kinds of food as well.

206. Volume of Food.-Besides the aigestible portions of the food, all animals require a certain volume of indigestible food. Nature has provided that they digest only a part of their food, and pass the undigested portion off as manure. It is possible to feed animals with certain foods all of which they can digest, and yet find that they do not do well on such a ration. Such foods are soon digested, leaving the stomach and intestines practically empty, and this condition of things is not good for the animal. Cattle, especially, require large amounts of food, as their stomachs are very large. The stomach of an ox is divided into four compartments, all of which together hold about 250 quarts. The stomach of the horse is much smaller, holding 
only 17 to 19 quarts; and the stomach of the hog holds only 7 to 9 quarts. The first compartment of the stomach in cattle serves as a sort of storehouse for food when first swallowed. Cattle, after chewing and swallowing their food, bring it back into the mouth from this first stomach, and after chewing it again, swallow it. This process is called chewing the cud. Sheep as well as cattle chew the cud, but the horse and pig do not.

\section{All the Foods Produced on the Farm May Be} Utilized.-The fact that different domestic animuls prefer different kinds of food enables the eareful stock man to use to advantage all the food produced on his farm. Cattle eat coarse fodder that horses will not touch, and hogs eat many foods unfit for either horses or eattle. Every pound of food produced may be used for stock of some kind. The coarsest fodder, if properly prepared, is readily eaten by cattle; and wheat straw, a poor food in itself, is useful for mixing with rich foods such as wheat bran or cottonseed-meal. Very coarse fodder should be run through a shredding machine before it is fed. A shredding machine tears the fodder into bits, in which condition it is more palatable to the animal. It is well to dampen very dry fodder before feeding, both to render it more palatable and to prevent the dust from it entering the nose and lungs of the animal to which it is fed. Many horses contract bad coughs from the dust rising from very dry fodder.

208. Experience and Observation Necessary.-The feeding standards in 'Table VIII are intended merely as guides for mixing the different foods that make up 
the ration. The kinds of food that make up the ration are determined according to the judgment of the person doing the feeding. Observation and experience are the best guides for selecting the proper foods, and every stock grower should, for his own satisfaction, try all the different stock foods within his reach. By keeping a record of each, he can determine which are best for his purpose. It is a bad plan to depend on only two or three foods; all animals like a variety of food, and if fed the same thing day after day they in time tire of it and lose their appetite.

209. Cost of Foods.-Foods costing the most money are not always the best, nor are the foods costing the least money always the cheapest. The author had occasion a few years ago to make analyses of many kinds of stock foods, and the results of a few of these analyses may serve as examples:

From a certain town a sample of food known as 66

's Food for Stock and Poultry" was obtained. An analysis showed that this food contained in every hundred pounds, approximately, 16 pounds of protein, $\gamma_{\frac{1}{2}}$ pounds of fat and 60 pounds of carbohydrates. An examination showed that the food consisted of wheat bran and corn-meal, with the addition of a little cottonseed-meal. To the food had been added a strong-smelling powder called fenugreek, which is of $\mathrm{r}_{1} \mathrm{O}$ value either as a food or medicine. This stock foorl sold at 6 cents a pound or $\$ 120$ a ton. From the same town, another sample of stock food, known as a mixed cattle food, was obtained. This food was also made up of wheat bran, corn-meal, and cottonseed-meal, but contained no fenu- 
greek. An analysis showed that every hundred pounds contained, approximately, $1 \%$ pounds of protein, 6 pounds of fat and 62 1 pounds of carbohydrates. This food sold for $\$ 17$ a ton, and contained more nutrients than the food sold at $\$ 120$. The digestibility of the two foods was practically the same. Persons buying the expensive food were paying $\$ 103$ extra for the addition of a little worthless fenugreek. There are many socalled prepared stock foods on the market, and for the most part they are not worth the prices charged for them. In buying any sort of prepared food or mill product, if there is any doubt as to the quality, a sample should be sent to the nearest chemist for analysis.

\section{Questions}

1. In mixing a ration what other things hesides the s.mount of digestible nutrients must be considered? 2. Why is it Irrportant to supply animals lood containing indigestible as well as digestible compounds? 3. About how many quarts coes the stomach of an ox hold? 4. What is the capacity of the horse's stomach? 5. How is the stomach of the ox divided up? 6. What is the purpoze of the first stomech of the ox? 7. What is meant by chewing the cud? S. I.ow is it possib.e to utilize all the food products on the farm? 9. Why is it advisable to try many different kinds of food in feeding animals? 10. Of what vaiue are most prepared stock loods? 


\section{PART VII.-MIscentuANeous Topics}

\section{CHAPTER XLI.-BIRDS}

210. Destruction of Birds.-In this age of ours a money value is the standard by which most things are judged. The first question is usually, "What is it worth?" Now, what are birds worth? They are pretty; many of them sing, and most kindly disposed persons enjoy seeing them about, but have they an actual money value? This question has been answered time and again, and the answer is always the same. Birds are of value, and they are of value to every living creature on this earth. It is not simply the birds that supply food for man and beast that are of value, but those pretty, bright little things that come each spring to enliven our country-robins, blackbirds, redbirds, orioles, swallows, and a host of others. Every year they come with the spring, and many of them spend their summer with us, but not as welcome guests. They are greeted with guns, sling-shots, traps, stones, hunted by . cats and dogs, robbed of their nests and eggs, persecuted by man and beast. Those unfortunates with bright, pretty feathers are killed that they may serve to ornament women's heads. We laugh at the poor Indian who decks himself with paint and feathers for some festive occasion; but each year thousands upon thousands of beautiful and useful birds are killed in order that women may adorn their heads, not with feathers 
only, but with whole birds, copying the fashion of the painted savage whom they scorn. Many thousands too die each year by the hands of so-called sportsmen; not game birds merely-such as turkeys, geese, duck, and partridges-but robins, larks, doves, nighthawks (bullbats), martins, and many other useful birds. To the average man with a gun everything with feathers is a game bird, and he slaughters without mercy. To the small boy the destruction of birds and their nests is a never-failing source of delight, and the murder of many helpless birds a thing to boast of. He kills merely for the love of killing, gratifying his brute instincts by putting to death ereatures too weak to defend themselves against attack. Men, women, and children are united with animals in a war on birds. Animals kill for food; inen and children mainly for the love of killing; women to satisfy their vanity. It would seem that in this case the beasts are endowed with higher motives than men and women.

211. Value of Birds.-But you say, birds steal fruit, they injure grain crops, some of them kill ehickens, and what use are they anyway? Did you ever see a tree stripped of its leaves by caterpillars or other insects? Did you ever see a fine fruit orchard dead or dying as though swept by a fire? Did you ever see a field of grain or grass eaten by an army of worms? Did you ever see a garden destroyed by worms or insects? Such things happen every year, and are becoming more and more common. Great armiss of insects are busy each year destroying.crops, trees, grass, and every green thing. The birds are busy destroying these inseets, and 
man is busy destroying the birds. Which is to succeed? If man succeeds, the insects will be left in peace to grow and multiply, and the destruction of all plant life will certainly follow. Chapman gives us an admirable description of how birds are constantly busy destroying insects: "Consider for a moment," he writes, "what the birds are doing for us in summer when the hum of insect life fills and becomes almost an inherent part of the atmosphere.

"In the air, swallows and swifts are coursing rapidly to and fro, ever in pursuit of the insects which constitute their sole food. When they retire the nighthawks and whippoorwills will take up the chase, catching moths and other nocturnal insects which would escape day-flying birds. The flycatchers lie in wait, darting from ambush at passing prey, and with a suggestive click of the bill returning to their post. The warblers, light, active creatures, flutter about the terminal foliage, and, with almost the skill of a humming-bird, pick insects from leaf or blossom. The vireos patiently explore the undersides of leaves and odd nooks and corners to see that no skulker escapes. The woodpeckers, nuthatches, and creepers attend to the tree trunks and limbs, examining carefully each inch of bark for insects' eggs and larvæ, or excavating for the ants and borers they hear at work within. On the ground the hunt is continued by thrushes, sparrows, and other birds who feed upon the innumerable forms of terrestrial insects. Few places in which insects exist are neglected; even some species whıch pass their earlier stages 
or entire lives in the water are preyed upon by aquatic birds."*

But birds are useful in other ways besides destroying harmful insects. There are many kinds of birds that live prineipally on the seed of weeds, and in this way destroy great numbers of weeds which would otherwise grow up to the hurt of farmers. Then there are still other kinds that make their living on field mice, rats, larger insects-grasshoppers, etc. Let us consider the work done by each of these classes of birds, beginning with the insect-eater, or insectivorous bird.

\section{Questions}

1. How are birds received when they come in the spring? 2. What harm do birds do? 3. What good do they do? 4. intc what groups are birds divided? 5. What are insectivorous birds?

- Report of Coun. Buard of Agr., 150\%, p. 76. 


\section{CHAPTER XLII.-Insectivorous BIRDS}

212. Damage Done by Insects.-Before taking up insectivorous birds, let us try to get some idea of the damage done to farm crops each year by insects.

Harmful insects feed mainly on the young and tender foliage of growing plants, but they also attack the seed, fruit, stem, and roots. In fact every portion of the plant is used as food by various insects, and no plant is safe from their attacks. Of course, not all insects are harmful. There are insects that prey on injurious insects, but, unfortunately, the harmful insects far outnumber the beneficial kinds. Birds prey largely on the injurious kinds.

A careful estimate places the average damage done annually by insects in the State of Illinois at twenty millions of dollars, which means that the damage averages 56 cents to each acre.* Fifty-six cents per acre for the damage done by insects is hardly an overestimate, and it is probable that there are few farmers whose crops are not damaged to this extent. But let us take for our example the State of Virginia and consider only the cultivated land. Forests we will not consider, though they are often much damaged by insect pests. We will assume that there are 9,000,000 acres of land under cultivation in Virginia, and that the crops from this amount of land are damaged by insects

* Report of Conn. Board of Agr., 1899. p. 78. 
to the extent of only 50 cents per acre. This would mean that insects destroy each year in Virginia four and one-half million dollars' worth of farm crops. If the damage were only 10 cents per acre, the loss would still be nearly a million dollars. But 50 cents is a low estimate; and we may safely say that each year in the State of Virginia four and one-half million dollars' worth of farm produce is destroyed by insects. This is an enormous loss, and the farmers should welcome any means of checking it.

213. Insects Eaten by Birds.-Now, have we no means at hand of lessening the number of destructive insects? Birds that make insects their principal food must destroy great numbers. Anyone who is at all observant must have noticed how many birds are constantly pursuing insects. The robin is busy most of the day, hopping about on the ground picking up the insects that constitute its food; we have all seen these birds at work, and also the many birds feeding in the air and on the trees. We must have noticed them. But if better proof than our own observation is desired, we have it from good authority. "Professor Forbes, Director of the Illinois State Laboratory of Natural History, found 1\%5 larvæ of Bibio-a fly, which, in the larval stage, feeds on the roots of grass-in the stomach of a single robin, and the intestines contained probably as many more." Another excellent authority states: "In a certain town where the elms had been ruined for several years, the cedar birds appeared and the elms were afterwards comparatively free from these

- Report ol Conn. Board ol Agt., 1990, p. 77. 
destructive bcetles. It has also been shown that thirty cedar birds would destroy 9,000 worms during the month when the cutworm caterpillar is exposed."*

We might add many hundred examples like the above to show the great number of insects destroyed by birds. It is very reasonable to suppose that the more birds we have about, the more insects will be eaten. Professor Forbes estimates the number of birds in Illinois at three individuals to the acre. $\uparrow$ In Virginia there are probably as many birds to the acre as there are in Illinois, so we may assume that there are three birds to each acre of. land in Virginia. This would give us for this State something like eighty million birds. Suppose that each bird destroys only one insect a day, it would mean the destruction of eighty million insects. One insect a day to each bird, however, is too low an estimate; twenty insects to each bird would be more probable. To be on the safe side, then, let us assume that twothirds of the total number of birds, or $53,000,000$, eat insects, and that each individual bird eats an average of ten insects a day. This would mean 530,000,000 insects destroyed each day by birds. Could there be a more effective way of destroying them? Could we but add to the number of insect-eating birds within the state of Virginia only one individual to each acre of ground, it would mean the destruction of millions of insects, and a saving of many thousand dollars to the farmers and fruit growers. Yet no efforts are made to increase the number of such birds; on the con-

*Report of Conn. Board of Agr., 1899, p. 83.

+Ibid, p. 77 . 
trary, it is probable that the number of these insecteaters is growing less each year.

214. The Birds that Eat Insects.-Now, what birds may be classed as insect-eaters? There are birds that live almost exclusirely on insects, eating practically r.o vegetable food; there are others that live on both insects and vegetable food; and there is still another class that lives almost exclusively on vegetable food, eating only a few insects. We can mention separately only a few of the commoner varieties of birds-those usually seen about the ąverage farm:

Under the class of insect-eaters we may mention swallows, of which there are several varieties; the best known being the barn-swallow, tree-swallow, eave or cliff-swallow, and the bank-swallow. These birds build about the dwellings of man, and may be seen during the day circling about in search of insects. As these birds live almost exelusively on insects, they are of much value, and their presence should be encouraged in every way possible. "It is said that cliff and barn-swallows can be induced to build their nests in a particular locality, otherwise suitable, by providing a quantity of mud to be used as mortar. Barn-swallows may also be encouraged by cutting a small hole in the gables of the barn." The purple martin also belongs to this family of birds, and is very useful as an insect-destroyer. The so-called chimney-swallow is not a swallow at all, but should be called a swift. It, too, feeds largely on insects. In the afternoons of summer and fall, we often see

-U. S. Dept. Agr. Farmers" Bulletin No. S4. 
numbers of nighthawks, commonly known as bullbats, darting about through the air in search of food. These birds live exclusively on insects, and should be protected, instead of being shot. The whippoorwill is a bird that works entirely by night, and it, too, lives on insects. Of all the insect-eating birds that inhabit farms, there is none of more value than the common house wren. Fully 98 per cent of its food is made up of insects, most of which work destruction to farm crops. The kingbird.is another insect-eater, and is also of value to the farmyard as a watchman, driving off birds of prey: The cuckoo also lives largely on insects, and is especially fond of caterpillars. The phœbe, a quiet little hird, lives almost exclusively on insects, and is a very valuable bird on the farm. There are five or . six different kinds of woodpeckers in the eastern United States, and they destroy many insects that prey on fruit and forest trees. They also eat some vegetable food, but do little or no damage to crops. The meadow lark, or old-field lark, is another bird that makes its living largely on insects. Its vegetable food consists of the seed of weeds. So it is of benefit to the farm in two ways. The brown thrasher is another insect-destroyer, more than half of its food being made up of insects. The bluebird eats mostly insects, which make up fully three-fourths of its food. The Baltimore oriole, famous for its beauty and song, is another insect-destroyer, and should be made welcome everywhere. The robin is a bird well known to everyone, but its value to the farm is far from being known. The robin, while it eats some vegetable food, destroys many harmful 
insects; about one-half of its food being made up of insects. The eatbird, against which there is such an unreasonable prejudice, is another insect-destroyer; about one-half of its food consists of insects. It is claimed that the bird destroys some fruit; but even if it does, it pays for all it takes by destroying hundreds of harmful insects; and in this way does more good than harm to the fruit grower.

There are many other birds that destroy insects, but we have not space to mention them all individually, and tell of their good work; so we must pass on to eonsider the seed-eating birds.

\section{Questions}

1. How do Insects damage growing crops? 2. At what stage of growth are most erops subject to the attacks of insects? 3. About what is the estimated damage per acro by insects in the State of Illinois? 4. About how many birds are there to the acre in Illinois? 5. About how many insects do birds eat a day in the State of Virginla? 6. Name a few of the best known insect-eating birds in your neighborhood. 7. Tell what you know about the k!nd of locd eaten by the fifferent birds with which you are familiar.

\section{PROBLEMS}

1. Supposn the annual damage from insects in your State averages 30 cents per acre, what is the yearly damage for the State?

2. Suppose there are four birds to the acre in your State, about how many will there be for the whole State?

3. Suppose each bird in your State eats five insects a day, how many will all the birds destroy in a week? 


\section{CHAPTER XLIII.-SEED-EAting BirdS}

215. The Destruction of Weeds.-The successful farmer must spend a part of his time and some money in fighting weeds. The amount of time and money he spends depends on how clean the keeps his farm. Weeds have been well defined as plants in the wron place. Naturally all thrifty farmers are interested in the destruction of weeds. They plow them under, they dig them up, and pull them out by hand, and yet some escape to start a new crop the next season. Most weeds produce great crops of seed; some weeds are known that produce about one hundred thousand seed to a single plant. If there were not some means of destroying at least a part of the seed produced by weeds, the world would soon be overrun with them. Fortunately, there are fully fifty different kinds of birds that eat the seed of weeds, and the amount of seed destroyed by these birds is enormous. We can only mention a few of the birds individually.

216. Birds that Destroy Weeds.-Probably the best known seed-eating birds are sparrows. Beal says of the sparrows that "there are some forty species, with nearly as many subspecies, in North America, but their differences, both in plumage and habits, are in most cases too obscure to be readily recognized, and not more than half a dozen forms are generally known in any one locality."*

*U. S. Dept. Agr. Farmers' Bulletin No. 54. 
To gire some idea of the amount of seed eaten by sparrows, Beal has made some estimates for the State of Iowa. He gives us figures for only one kind of sparrow, namely, the tree-sparrow, which is very abundant in the Northern States. He begins by estimating that there are ten sparrows to each square mile, or one spatrow to sixty-four acres. If, as he says, each spartow eats daily an average of one-fourth of an ounce of seed for two hundred days, they destroy in that State alone $1,750,000$ pounds, or $8 \% 5$ tons of weed-seed; allowing 20,000 pounds to a car-load, this is enough seed to load a little over eighty-seven cars. Besides this one kind of sparrow there are many others that eat largely of seed, and the amount of seed destroyed must be much larger than these figures show. Suppose instead of being eaten by birds this vast quantity of seed were to grow up as weeds, what would become of the farmers? In the Southern States, while we have not the treesparrow, we have a number of equally useful varieties, such as the white-throated sparrow, the white-crowned sparrow, the song-sparrow, the field-sparrow, the foxsparrow, and a number of others. Just stop a moment and try to think of the rast number of weed-seed eaten each winter by the sparrows in each State. Even the much abused English sparrow is known to eat the seed of many weeds.

Beal says: "While sparrows are noted seed-eaters, they do not by any means confine themselves to a vegetable diet. During the summer, and especially in the breeding season, they eat many insects, and probably feed their young largely upon the same food. An ex- 
amination of the stomachs of three species-the song sparrow, the chipping sparrow and the field sparrowshows that about one-third of the food consists of insects, comprising many injurious beetles, such as snoutbeetles or weevils; and leaf-beetles."*

Besides the sparrow there are a number of other kinds of birds noted as seed-destroyers. The goldfinch, or wild canary, is very useful in this respect. Redbirds, horned larks, and blackbirds are also seed-eaters. The blackbirds with which we of the southeastern States are most familiar are the crow blackbird, or grackle, and the red-winged blackbird. Both of these birds are accused of stealing grain from cultivated fields, and it is very probable that they do some damage in this way; but, on the other hand, they eat quantities of weed-seed and also many insects.

Besides the birds already mentioned, there are several so-called game birds that are seed-eaters. 'The quail, or bobwhite, lives largely on the seed of weeds, and does no harm to grain fields. The mourning dove is another bird that eats great quantities of weed-seed.

Dr. Sylvester Judd, of the United States Department of Agriculture, says of seed-eating birds: "No less than fifty different birds act as weed-destroyers, and the noxious plants which they help to eradicate number more than threescore species." $\dagger$

217. Birds and Cultivated Crops.-On the other hand, it is undoubtedly true that some birds do damage to both grain crops and fruit crops. The crow and the

*U. S. Dept. Agr. Farmers' Bulletín No. 54.

tYearbook U. S. Dept. Agr., 1898, p. 232. 
two kinds of blackbirds already mentioned are the chief offenders, and in some sections of the country they are considered pests. Where the blackbirds gather in very large flocks they do considerable damage to grain. But it is very probable that the destruction of grain is due to the lack of other food, for even when they can get cultivated grain these birds eat weed-seed and insects, and while they do some damage they certainly do some good.

The crow is aceused of pulling up young corn, and is probably guilty of this crime; but, on the other hand, about 25 per cent of the erow's food consists of harmful inseets, and the number of such insects destroyed by crows must be immense.

Robins, cathirds, and mocking-birds are often accused of taking fruit, but the best testimony goes to show that the value of the fruit eaten by them is but small, and is paid for many times over by the number of harmful insects destroyed.

\section{Questions}

1. What aid the farmer in his fight against weeds? 2. About how many kinds of birds are known to eat the seed of weeds?. 3. Name some of the best known seedeating birds. 4. Give some idea of the amount of seed eaten by the tree sparrow in Iowa. 5. What can you say in defense of the blackbird and the crow?

\section{PROBLEM}

Suppose that In your State there are ten sparrows to each square mfle, and that each sparrow eats one-fourth of an ounce of seed a day for one hundred and fifty days. How many pounds of seed will be eaten during that time in the State? How many car-loads will that amount of seed make, allowing 20.000 pounds to the car? 


\section{CHAPTER XLIV.-Birds of Prey}

\section{Prejudice Against Hawks and 0wls.-We come} now to a class of birds a part of whose food consists of small animals and birds. They are known as birds of prey. The birds of prey in which we are interested are generally known as hawks and owls, and of both there are a number of different kinds. Against all birds of prey alike, there exists the strongest prejudice; they are without exception condemned, and, whenever the opportunity oflers, cxecuted without trial. This condemnation of all birds of prey without trial is hardly just. We accord to our basest criminals a patient hearing. Why, then, should we not listen to a few words in defence of birds of prey? But few people will ever listen to a word spoken in defence of hawls or owls; thcy condemn the whole class. The innocent must suffer for the sins of the guilty, for but few persons are willing to believe in an innocent hawk or owl. Yet there are hawks and owls not only innocent of all wrong agrainst man, but actually of great benefit to agriculture. It is certainly unjust to condemn these birds to death because a few of their cousins have been known to steal poultry. It would be just as reasonable to condemn a whole family to death because one member was a thief; or to judge the character of the human race by a few criminals. But, you may object, how can this prejudice against hawks and owls have become so universal without good foundation? That there is some founda- 
tion for the feeling is very true. There are hawks and owls that attack poultry or small game whenever the opportunity offers, but this is by no means true of the whole race. There are many kinds of hawks and owls that are never known to touch poultry. Unfortunately, few persons can distinguish the different kinds of hawks or owls. They see some bird of prey attack their fowls and at once condemn, and, whenever possible, kill all birds that resemble it. In doing this they kill many innocent birds, and very probably never reach the guilty one; for the birds that rob the henroosts are very quick and shy, and fully realize the danger from a gun. On the other hand, their cousins who never touch a domestic fowl, and come, conscious of their innocence, in search of mice or insects, are greeted with shot intended for the thief.

Unfortunately, it would require far too much space for us to attempt to describe each kind of hawk and owl. We ean, however, tell of some of their good deeds as compared with the harm that they do, and urge on all to give to these valuable birds at least a fair trial. The harm that these birds do is easily told: the good that they do would fill a volume. Let us see what they have done to bring upon themselves the curse of man.

219. Harm Done by Hawks and 0 wls. - The grentest crime of which these birds are aceused is the destruction of poultry and game birds. Now, there are only two kinds of hawks commonly found in the United States that feed principally on the flesh of other birds. These are known as Cooper's hawk, and the sharp-shinned hawk, and are much alike in appearance, Cooper's hawk 
being the larger. These birds are very quiet and shy, darting suddenly on their prey from some hiding-place. Rarely are they seen soaring over fields or heard calling. There are two other bird-eating hawks sometimes seen in the country, the goshawk and the duck-hawk, but, fortunately, they are few in numbers. These four kinds of hawk are harmful, as they destroy many.useful birds, and do little, if any, good. All the other hawks and owls known in the United States do good as well as harm. Some kinds are entirely beneficial, others principally beneficial, and still others in which the beneficial and harmful qualities are about equally balanced. To recognize these many kinds of birds requires more time and study than the average farmer can devote to it. How then can he punish the guilty without the innocent suffering? Chapman says: "The only safe way to give justice to whom justice is due is to kill only the hawks we actually see taking our chickens, and not murder indiscriminately every member of the hawk family."*

There are only a few owls known in this country that ever disturb poultry, and they also do much good in destroying many mice and rats. The owls work only at night, and when poultry are provided with a home they are perfectly safe from this bird.

220. Value to the Farmer of Birds of Prey.-In the report for 1886, Dr. C. H. Merriam, chief of the Biographical Survey of the Department of Agriculture, gives some interesting figures showing the value of birds of prey in Pennsylvania. "On the 23d of June, 1885,"

*Report of Conn. Board of Agr., 1899, p. 103. 
he tells us, "the Legislature of Pennsylvania passed an act known as the 'scalp act,' ostensibly 'for the benefit of agriculture,' which provides a bounty of 50 cents each on hawks, owls, weasels, and minks killed within the limits of the State, and a fee of 20 cents to the notary or justice taking the affidavit.

“ By virtue of this act about $\$ 90,000$ has been paid in bounties during the year and a half that has elapsed since the law went into effect. This represents the destruction of at least $128,5 \% 1$ of the above-mentioned animals, most of which were hawks and owls.

"Granting that 5,000 chickens are killed annually in Pennsylvania by hawks and owls, and that they are worth 25 cents each (a liberal estimate in view of the fact that a large portion of them are killed when very young), the total loss would be $\$ 1,250$, and the poultry killed in a year and a half would be worth $\$ 1,8 \%$. Hence it appears that during the past eighteen months the State of Pennsylvania has expended $\$ 90,000$ to save the farmer a loss of $\$ 1,875$. But this estimate by no means represents the actual loss to the farmer and taxpayer of the State. It is within bounds to say that in the course of a year every hawk and owl destroys at least a thousand mice or their equivalent in insects, and that each mouse or its eqnivalent so destroyed would cause the farmers a loss of two cents per annum. Therefore, omitting all reference to the numerous increase in the numbers of these noxious animals when nature's means of holding them in check has been removed, the lowest possible estimate of the value to the farmer of 
each hawk, owl, and weasel would be $\$ 20$ a yeąr, or, $\$ 30$ in a year and a hall.

"Hence, in addition to the $\$ 90,000$ actually expended by the State in destroying 128,571 of its benefactors, it has incurred a loss to its agricultural interests of at least $\$ 3,85 \%, 130$, or a total loss of $\$ 3,94 \%, 130$ in a year and a half, which is at the rate of $\$ 2,631,420$ per annum. In other words, the State has thrown away $\$ 2,105$ for every dollar saved! And even this does not represent fairly the full loss, for the slaughter of such a vast number of predaceous birds and mammals is almost certain to be followed by a correspondinglý enormous increase in the numbers of mice and insects formerly held in check by them, and it will take many years to restore the balance thus blindly destroyed through ignorance of the economic relations of our common birds and mammals."*

A statement such as this from so reliable an authority as Dr. Merriam should go far towards convincing us of the folly of destroying all kinds of hawks and owls.

\section{Questions}

1. What is meant by birds of prey? 2. Name the two commonest kinds of birds of prey. 3. Can you explain why such a strong prejudice exists against all hawks and owls alike? 4. How do most hawks and owls benefit farmers? 5. About how many kinds of hawks are there in the United States that live exclusively on the flesh of other birds? 6. Name the two commonly found in this country that live on the flesh of other birds. 7. Give an account of the working of the "Scalp Act" in Pennsylvania.

Report of Conn. Board of Agr., 1899, p. 94. 


\section{PROBLEM}

Take the total number of acres of cultivated land in your State, and suppose there are two field mice to each acre, and that each mouse eats two cents worth of tood per year. What is the value of the food eaten by the mice? If the hawks and owls eat one mouse for each two acres of land, what is the value of lood saved? 


\section{CHAPTER XLV.-FORESTRY}

221. Definition.-Forestry is the art of growing and caring for trees; it is tree-farming. In this great country of ours we are inclined to look on tree-farming as a useless occupation. With such vast forests as ours it seems useless to plant and grow more trees. But at the present rate, how long will our forests last? Each year many thousand trees are cut, and it takes many years for others to grow in their place. A great tree may be cut down in a few minutes; but it requires fifty to one hundred years for another to grow in its place. Our forests are being cut away much faster than others are growing, and unless our government takes some measure to protect them, the forests of this country will all be destroyed.

222. Value of Forests.-Besides supplying timber, forests are of value in many ways:

(1) In the first place forests have a great influence on the climate of a country. The trees through their leaves give off vast quantities of water, which serves to keep the air in the immediate vicinity of the forest moist. The moisture in the air serves to equalize the temperature, preventing sudden extremes of heat and cold.

(2) Forests' prevent excessive surface washing, causing the rains and snow to soak into the soil; thus increasing the flow of water from springs, wells, and creeks, and at the same time preventing floods. The 
great floods that occur each year in our rivers are, in a large measure, due to the cutting away of the forest about the sources of the rivers. There being no trees to stop its flow, the water rushes away in gullies to increase the volume of creeks and rivers. The dreadful floods that take place ench year in the great Mississippi River are no doubt made worse by the cutting away of the forests which surround its headwaters. There is every reason to believe that the floods in this rirer will grow worse as more of the forest in the valleys is cut away.

(3) Forests prevent in a great measure the surface evaporation which takes away such rast quantities of water from traeless soill. 'Through surface evaporation and surface washing, soils from which trees hare been cut, unless continually cultivated, are apt to suffer. The cutting of timber is often followed by forest fires that destroy the undergrowth, leaving the soil bare to the action of wind and rain. In this condition it loses moisture, loses fertility, and quickly becomes waste land. The cutting away of forests always lessens the water supply.

(4) Forests are a great protection against windstorms; they protect cultivated crops from both the cold winds of winter and the hot, drying winds of summer.

223. Destruction of Forests.-Vast numbers of trees are cut every year for timber, and often the cutting is so carelessly done that many young trees are injured or destroyed. The modern process of manufacturing paper from wood pulp is also responsible for the 
destruction of much timber. Soft timber is principally used in this process, and the amount of timber cut annually is immense. But the great forest destroyer is fire; each year vast areas of wooded land are burned over, and most of the young timber destroyed. After a forest has been cut, the young timber, if left undisturbed, will in twenty-five to forty years produce a new forest, but after a fire there are few young trees left to grow. Each State has laws against starting forest fires, imposing as penalties heavy fines or imprisonment. Unfortunately, the law is never enforced, and fires that destroy thousands of dollars' worth of timber are sometimes started merely for the sake of obtaining a few chestnuts. Besides destroying the young growth, forest fires, which usually occur in the fall, leave the land comparatively bare to the action of winter rains, which do much injury to the exposed soil.

Lumber companies buy up great areas of forest land merely for the lumber; they cut off the trees, caring nothing for another crop, and after obtaining the lumber often leave the land to the action of fire and water. Under the present system of management the forests of the United States will certainly be destroyed in a comparatively few years, and the next gencration will have to begin to grow trees as a regular crop. Conservative estimates show that at the present rate of destruction the forests of the United States will not last more than fifty years.

224. Tree-Growing for Profit.-Forestry among other things teaches us how to grow crops of trees for market. By exercising the proper amount of care and 
following a few simple rules, any one who owns timber land may harvest a crop of timber just as regularly as he harvests wheat or corn. Let us suppose the case of a farmer who owns 200 acres of woodland and wishes to derive an income from the sale of timber. Now, he can in a short time cut all of his trees that are fit for lumber, but if he wishes another crop from the same land he must wait many years. If, however, he wishes to derive a steady income from his timber he can cut only a part of it each year. He can divide his 200 acres into sections of say ten acres each, and cut the timber from one section each year; being careful to protect the young timber from harm. By the time he has cut over his 200 acres the young timber on the first ten acres cut has had twenty years added to its growth, and much of it will be ready for cutting. In this way he derives a steady annual income from his timber. Instead of cutting each year, he may cut a certain area every two, three, or four years; say twenty acres every other year, or twenty-five or thirty acres every three years. By following some system such as this he can derive a steady income from his timber land, and yet hand it down to future generations uninjured.

225. Growing Trees for Shade or Ornament.-Aside from their value in forests, trees are of value for ornamental purposes and for the production of shade. How delightful after a hot walk to enter the cool shade of a group of trees! Man or beast toiling along a hot, dusty road hails with joy the appearance of a tree, yet how few of our public highways are provided with shade - trees. In building a road the destruction of all shade 
trees is often the first object. Miles and miles of road stretch away without so much as a bush to shield the traveler from the fierce summer sun. The idea prevails that trees keep a roadbed damp, but this is true only where the soil is naturally very damp. A properly constructed road is never injured by shade trees, but on the other hand is made very much more comfortable for travelers.

No pasture should be without its group of shade trees; if unprovided with shade, animals suffer very much from the summer sun. In the heat of the day they love to collect in the shade of some tree and wait for the cooler hours of the day, during which they feed. No pasture is complete without its shade trees for the protection of animals during the heat of the day.

For ornamenting and shading the grounds about dwellings, trees are often grown, and for this purpose various kinds of trees and shrubs are used according to the fancy of the owner. No country home is complete without its setting of ornamental trees or shrubs, and the market value of a place may be increased by a growth of trees or shrubs about the house.

\section{Questions}

1. What is forestry? 2. Have forests any effect on the climate of a country? 3. If so, how? 4. How do forests protect the surface or the land? 5. How do forests check the formation of floods? 6. How do forests protect the soil from surface evaporation? 7. How are forests destroyed? 8. Is there any law in your State against starting forest fires? 9. Does the cutting away of the older trees necessarily destroy a forest? 10. How may a piece of woodland be made to yield an annual crop of timber? 11. Of what value are trees in a pasture? 12. Of what value are trees planted about a home? 


\section{CHAPTER XINI.ROADS}

226. Growth of Interest in Good Roads.-There is an old saying to the effect that one may judge of the civilization of a country by its roads-the better the roads, the higher the civilization. Savages have no roads; the old Romans built roads that are in use to-day. France, Germany, England, and the older countries of Europe have far better roads than we have in the United States. It is in only a few of the more progressive States of our country that any roads worthy of being called good are to be found. But the interest in good roads is growing, and their value to the country through which they run is gradually being recognized. It is a hard matter to convince the tax-payer that a few dollar: expended on road improvement will prove a paying investment; but the lesson is being learned, and will in time result in good roads.

227. What is Meant by a Good Road.-Now, what iș meant by a good road? By the term good road, as ordinarily used, is meant a permanent road, the surface of which remains hard and smooth regardless of the weather, and which may be easily traveled at all seasons. It is a road built to be used by many generations. Most of our so-called roads are not really roads at all; they are trails, and are mored about to suit existing conditions. The building of roads such as are generally known in this country is a simple process, one that has been handed down for thousands of years. The first 
step is to remore trees and other impassible obstructions; in enterprising communities the stumps are sometimes dug up, but the usual method is to le:ive them to be worn away by time and the wheels of passing vehicles. If the land be of sufficient value, the trail is fenced on either side to prevent its becoming too wide. Over this clearing, which is expected to grow with no assistance into a fully developed road, one vehicle follows in the track of another until a well-marked way is established; and usually deep ruts are cut into the carth, and in damp places great pools of mud are churned up. When the ruts and mudholes become too deep to be conveniently filled with loose stones, or old fence rails, a new trail is opened around them. In this manner. the course of the road is constantly changing. It is seldom that any grading is attempted. The trail wanders across the country from house to house, dodging the worst obstacles, and finally, after many windings, reaching its destination.

The building of permanent highways is the business of the engineer, but every farmer should know something of road-making and road-mending.

228. Dirt Roads. - A dirt road is one that uses the natural surface of the ground with no attempt at improvement except such as is obtained by drainage and grading.

(1) In locating roads of any kind the first object should be to avoid steep grades. On dirt roads the grade should never be more than 7 per cent, which means a rise of 7 feet in every 100 , or 369 feet per mile. As the steepness of the grade increases, the load hauled 
must decrease. According to Gillespie, if a horse can pull on a level 1,000 pounds; on a rise of 1 foot in 100 , or 1 per cent, he can pull 900 pounds; on a rise of 1 foot in 50 , or 2 per cent, he can pull 810 pounds; on a rise of 1 foot in 25 , or 4 per cent, he ean pull 510 pounds; and on a rise of 1 foot in 10 , or 10 per cent, he can pull only 250 pounds. 'These figures show how important it is to aroid very steep grades.

(?) Good drainage is equally as important as good grades. Wet spots in the road, if neglected, soon become mudholes which prevent the hauling of anything but light loads. All wet portions of the road should be underdrained, just as wet fields are drained, the drains

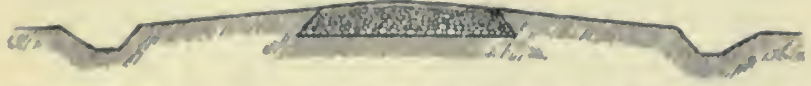

Fio. 21.-Sectlon of macadam road with dirt tracks on elther side. shows ditches for surface dralnage. (After a drawing In Yearbook, U. S. Dept. Agr., 1894, page 602.)

being constructed in the same way. To carry off the surface drainage, open ditehes on either side of the road - should be construeted. The drainage ditches must, of course, hare some outlet into some creek or gully. A few dollars carefully expended in draining a road may change an almost impassable road into a fairly good one. Unless properly drained no road can be kept in good condition.

(3) The surface of the road should be wide enough to accommodate all travel, and the center should be higher than the sides. Fig. 24 shows how the surface of a well constructed road is built up. The center of the road should be just high enough above the ditches 
to cause all the surface water to run off. If too high, it is apt to wash.

229. Stone Roads.-However well graded and drained dirt roads may be, they are certain to become muddy in wet weather; and from the passing of many vehicles, are much cut up into holes and ruts. To avoid this, the surface of the road or track may be covered with some hard material, such as broken rock, gravel, or oyster shells, which does not become soft in wer weather. Broken rock is the material most generally employed, and when properly used makes the most durable of all roads. There are two kinds of stone roads in genẹral

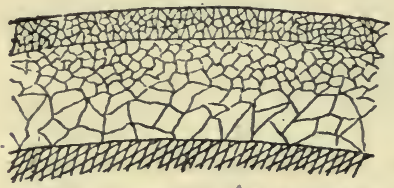

FiG. 25.-Section of macadam road.

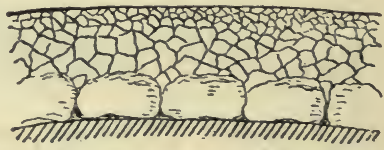

FIG. 20.-Section of telford road.

use. One was designed by a Scotchman named Macadam, and is called a MACADAM ROAD, the other was designed by another Scotchman named Telford, and is called A TELFORD ROAD.

230. Macadam Roads. - The macadam road is built by using first a layer of broken rocks, rrone of the pieces to exceed three inches in diameter; the layer is rolled and packed. On this is placed another layer of smaller pieces of crushed rock, which is likewise rolled and packed. Lastly, a layer of finely crushed rock is put on, and, after being wet, is heavily rolled.

231. Telford Roads.-The telford road is somewhat similar to the macadam, except that in place of the first 
laxer of coarse broken rock, a layer of flat stones is laid in a regular course. On this the road is built up like the macadam. Fig. 25 shows a section of a macadam road, and Fig. 26 a section of telford.

A well constructed macadam or telford road will last for many years, and costs little or nothing to keep in good repair, Stone roads should have dirt tracks on one or both sides. A dirt track is pleasant to use in dry weather, and saves wear on the stone track. Fig. 24 shows such a road.

232. Value of Good Roads to a Community.-Cood road́s provide better schools and better education, better churches and better morals, better health and greater happiness, more money and better business.

(1) The value of country schools depends largely on the condition of the roads. When the roads become very bad, many children are prevented from attending school regularly, and both the school and children suffer. It is not unusual for country schoods to be closed for weeks at a time on account of the condition of the roads. Many country people who wish to provide their children a good education are forced to move into some town to secure it. It is useless to expect first-class country schools without good country roads.

(2) Churches in the country are as much dependent on good roads as country schools are. When the roads are very bad, many people stay away from church, the church suffers, and the people gradually become indifferent about attending at all. They become lax, and the morals of the community suffer. $A$ country without 
good roads can have neither first-class schools nor first-class churches.

(3) The happiness of most people is, to a large measure, dependent on the society of their neighbors. Few people can be happy when forced to lead the life of a hermit. In many country districts the women and children are for months cut off from all society. They become practically prisoners, for not only are they cut off from society, but they are prevented from taking any form of outdoor exercise. They are confined to the house or yard, and suffer both physically and mentally.

It is no very unusual thing for persons in the country to be far removed from all medical assistance; and persons cut off from the doctor have died from want of proper treatment. Good roads bring more and better society, more health and happiness, and better doctors.

(4) By greatly reducing the cost of marketing crops, good roads increase the farmer's profit. The old saying, "time is morey," is particularly applicable to the farmer during his busy seasons. Over good roads he can in the same time handle almost twice as much produce with less wear and tear on his teams than over roads that are full of rocks and mudholes.

When we remember that all the produce of the farm, in order to find a market, must pass over some sort of road, we can realize how important is the question of good roads to the farmer. In this connection, some figures prepared by the U. S. Department of Agriculture are of interest: 
Cost of Hauling lxism Pronluere in the Unitsal Strtes.

\begin{tabular}{|c|c|c|c|c|}
\hline & 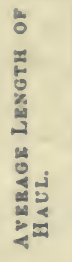 & 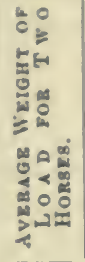 & 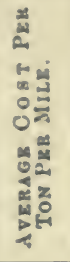 & 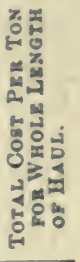 \\
\hline & MILRS & POLIDDS & CBSTS & \\
\hline Fastern States ................. & 5.9 & 2,216 & 32 & $\$ 1.89$ \\
\hline Northern States................ & 6.9 & $\ldots \ldots$ & 27 & 1.86 \\
\hline Middle-Southern States. . . . . . . . . . & 8.8 & & 31 & 2.72 \\
\hline Cotton States . . . . . . . . . . . . & 12.6 & 1,397 & 25 & 3.05 \\
\hline 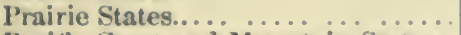 & 8.8 & 2,409 & 22 & 1.94 \\
\hline Pacitic Coast and Mountain States. & 23.3 & 2,197 & 22 & 5.12 \\
\hline A verage for the United States..... & 12.1 & 2,002 & 25 & $\$ 3.02$ \\
\hline
\end{tabular}

" The total weight of farm products in 1895 was estimated at $219,824,227$ tons; if the forest products hauled over the public roads be added to this, we get $313,349,227$ tons, which at $\$ 3.02$ per ton, makes a total for the annual cost of hauling on public roads of $\$ 9.16,414,665$. Nearly, if not quite, two-thirds of this vast expense may be saved by road improvement, and this at a total cost of not exceeding the losses of three, or at most four, years by bad roads." (Circular 19, Office of Road Inquiry, U. S. Dept. Agr.)*

\section{Questions}

1. How may the civilization of a country be judged? 2. What countries have the best roads at the present time? 3. What is meant by a good road? 4. Are there many miles

-Ilandbook for Farmers and Dalrymen, F. W. Woll, p. 160. 
of good road in your State? 5. In locating a road why is it important to consider the grade? 6 . Why is the drainage of a road important? 7. What happens to the surface of a dirt road in wet weather? 8 . What is a stone road? 9. Name two well known kinds of stone roads. 10. Tell how a macadam road is constructed. 11. Tell how a telford road is constructed. 12. How do good roads improve country schools? 13. What effect have good roads on country churches and on the morals of a community? 14. How do good roads affect the society of a community?

\section{PROBLEM}

If it costs 30 cents to haul one ton a mile, how much will it cost to haul 5,000 pounds of tcbacco eight miles? 
Appendix of Useful Tables. 



\section{COMPOSITION OF MANURES}

\section{TABLE I}

Nitrogenms Manures

\begin{tabular}{|c|c|c|c|}
\hline \multirow{2}{*}{ ARTICLF. } & \multicolumn{3}{|c|}{ POUNDB PER UUNDRED. } \\
\hline & Nitrogen. & $\begin{array}{c}\text { Phosphorie } \\
\text { Acld. }\end{array}$ & Potash. \\
\hline 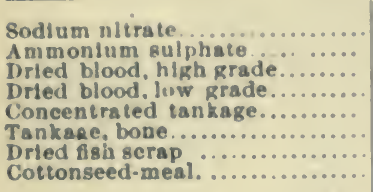 & 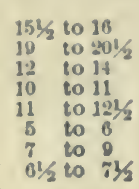 & 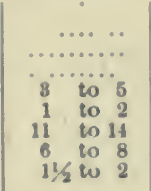 & 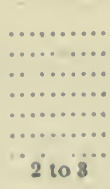 \\
\hline
\end{tabular}

\section{TABLE II}

Phosphatic Manurcs

\begin{tabular}{|c|c|c|c|c|}
\hline \multirow{3}{*}{ ARTICLE. } & \multicolumn{4}{|c|}{ POUSDS HER HUNDRED. } \\
\hline & \multicolumn{3}{|c|}{ Рноsphoric ActD. } & \multirow{2}{*}{ Nitrogen. } \\
\hline & Avallable. & Insoluble. & Total. & \\
\hline 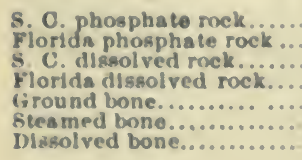 & $\begin{array}{l}\text { is to } 15 \\
14 \text { to } 16 \\
5 \text { to } 8 \\
6 \text { to } 9 \\
13 \text { to } 15\end{array}$ & $\begin{array}{l}28 \text { to } 28 \\
23 \text { to } 25 \\
1 \text { to } \\
1 \text { to } \\
15 \text { to } 17 \\
16 \text { to } 20 \\
2 \text { to } 8\end{array}$ & $\begin{array}{l}26 \text { to } 28 \\
35 \text { to } 25 \\
13 \text { to } 16 \\
16 \text { to } 20 \\
20 \text { to } 25 \\
22 \text { to } 22 \\
15 \text { to } 17\end{array}$ & 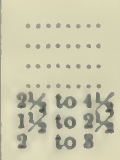 \\
\hline
\end{tabular}


Composition of Manures-Continued

\section{TABLE III}

Potassic Manurcs

\begin{tabular}{|c|c|c|c|c|}
\hline \multirow{2}{*}{ ARTICLE. } & \multicolumn{4}{|c|}{ Pounds Per Hundred. } \\
\hline & Potash. & $\begin{array}{c}\text { Phosphoric } \\
\text { Acid. }\end{array}$ & Lime. & Chlorine. \\
\hline 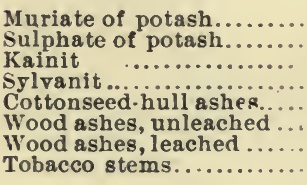 & $\begin{array}{l}50 \\
48 \text { to } 52 \\
12 \text { to } 121 / 2 \\
16 \text { to } 20 \\
21) \text { to } 30 \\
2 \text { to } 8 \\
1 \text { to } 2 \\
5 \text { to } 8\end{array}$ & $\begin{array}{l}\cdots \cdots \cdots \\
\cdots \cdots \cdots \\
\cdots \cdots \cdots \\
7 \text { to } 9 \\
1 \text { to } 2 \\
1 \text { to } 11 / 2 \\
3 \text { to } 5\end{array}$ & $\begin{array}{l}\cdots \cdots \\
\cdots \cdots \\
\cdots \cdots \\
10 \\
30 \text { to } 35 \\
35 \text { to } 40 \\
31 / 2\end{array}$ & $\begin{array}{l}45 \text { to } 48 \\
1 / 2 \text { to } 11 / 2 \\
30 \text { to } 32 \\
42 \text { to } 46 \\
\cdots \cdots \cdots \\
\cdots \cdots \cdots \\
\cdots \cdots \cdots\end{array}$ \\
\hline
\end{tabular}

\section{TABLE IV}

Average Composition of $\dot{F}$ arm Manurcs

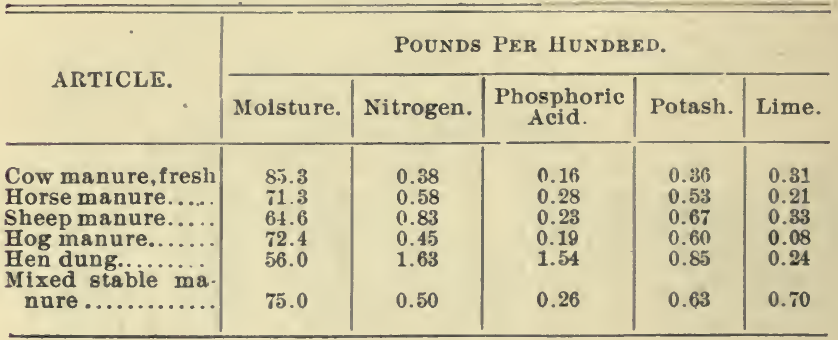




\section{STOCK FOODS}

\section{TABLE $\mathrm{V}$ \\ Arerage Composition of Stock Fonds}

\begin{tabular}{|c|c|c|c|c|c|c|}
\hline \multirow{2}{*}{ NAME OF FOOD. } & \multicolumn{6}{|c|}{ POUNds PER HUxderd. } \\
\hline & $\stackrel{\vdots}{\leftrightarrows}$ & 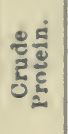 & $\underset{3}{0}$ & 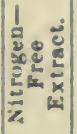 & 蓆 & $\begin{array}{l}\sum_{0}^{\infty} \\
\substack{0 \\
0 \\
0 \\
0}\end{array}$ \\
\hline \multicolumn{7}{|l|}{ Green Food and Ensilage. } \\
\hline 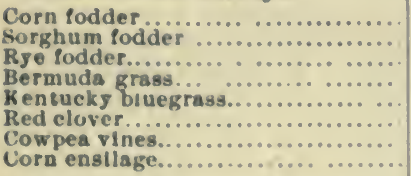 & $\begin{array}{l}79.8 \\
69.4 \\
76.6 \\
71.7 \\
65.1 \\
70.8 \\
83.6 \\
79.1\end{array}$ & $\begin{array}{l}1.8 \\
1.6 \\
2.6 \\
2.2 \\
1.1 \\
1.4 \\
2.4 \\
1.7\end{array}$ & $\begin{array}{l}0.5 \\
1.6 \\
0.6 \\
0.9 \\
1.8 \\
1.1 \\
0.1 \\
0.8\end{array}$ & $\begin{array}{r}12.2 \\
13.8 \\
6.8 \\
17.8 \\
17.6 \\
13.5 \\
7.1 \\
11.0\end{array}$ & $\begin{array}{r}5.0 \\
8.8 \\
11.6 \\
5.9 \\
9.1 \\
8.1 \\
4.8 \\
6.0\end{array}$ & $\begin{array}{ll}1 & 2 \\
1 & 8 \\
1 & 8 \\
2 & 0 \\
2 & 8 \\
2 & 1 \\
1 & 8 \\
1 & 1\end{array}$ \\
\hline \multicolumn{7}{|l|}{ Hay and Other Dry Coarse Fudder. } \\
\hline 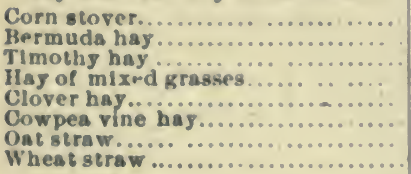 & $\begin{array}{r}10.5 \\
9.5 \\
13.2 \\
12.9 \\
15.8 \\
10.7 \\
9.2 \\
9.6\end{array}$ & $\begin{array}{r}3.8 \\
8.9 \\
5.9 \\
10.1 \\
12.8 \\
16.6 \\
4.0 \\
8.4\end{array}$ & 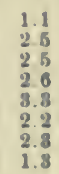 & $\begin{array}{l}81.5 \\
17.9 \\
45.0 \\
41.3 \\
38.1 \\
42.9 \\
12.4 \\
13.4\end{array}$ & $\begin{array}{l}19.7 \\
25.11 \\
29.0 \\
27.6 \\
21.8 \\
20.1 \\
37.0 \\
88.1\end{array}$ & $\begin{array}{ll}3 & 1 \\
6 & 2 \\
1 & 4 \\
5 & 5 \\
6 & 2 \\
7 & 5 \\
5 & 1 \\
4 & 1\end{array}$ \\
\hline \multicolumn{7}{|l|}{ Rool Crops. } \\
\hline 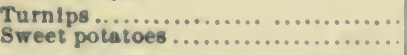 & $\begin{array}{l}90.5 \\
68.4\end{array}$ & $\begin{array}{l}1.1 \\
1.9\end{array}$ & $\begin{array}{l}0.2 \\
0.7\end{array}$ & $\begin{array}{r}6.2 \\
26.8\end{array}$ & 12 & $\begin{array}{l}0.8 \\
1.1\end{array}$ \\
\hline \multicolumn{7}{|l|}{ Grain Crops and Other Seed. } \\
\hline Corn ........ & 10.9 & 10.5 & 5.4 & 69.6 & 2. & 1.5 \\
\hline (n................. & 11.0 & 11.8 & 6.0 & B9. 7 & 9. & 8 \\
\hline Barley.. & 10.9 & 12.4 & 18 & 698 & 2. & $2+$ \\
\hline Wheat. & 106 & 11.9 & 2 & 719 & & 18 \\
\hline Cowpeas. .... & 12.2 & 21.2 & 1. & B. 1 & 4 & $8-1$ \\
\hline 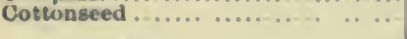 & 9.9 & 19.4 & 19.3 & 23.9 & 22.6 & $4 \div$ \\
\hline \multicolumn{7}{|l|}{ Mill Products. } \\
\hline Corn meal. . & 18.0 & 9.2 & 3. 8 & 6.8 & 1.9 & 14 \\
\hline Corn and cob : & 15.1 & $8 \overline{5}$ & 8.6 & 64. 8 & 0.6 & i. \\
\hline Corn bran.... & & 90 & 5. 8 & 68.1 & 12.7 & 18 \\
\hline Wheat bra & 110 & 15.4 & 4.0 & 88.9 & 9.0 & 8 i \\
\hline Wheat $m$ ! & 121 & 156 & 1.0 & 60.4 & 1.6 & 83 \\
\hline Cottonser & 8.5 & 48.3 & 18.6 & 22,3 & 8. & 70 \\
\hline Cotwonseed-bulls. & 10.5 & 1.1 & 2.2 & 86.9 & 48. 8 & 2.7 \\
\hline
\end{tabular}




\section{Stock Foods-Continued}

\section{TABLE VI}

Per Cent of Nutrients Digestible in Stock Foods

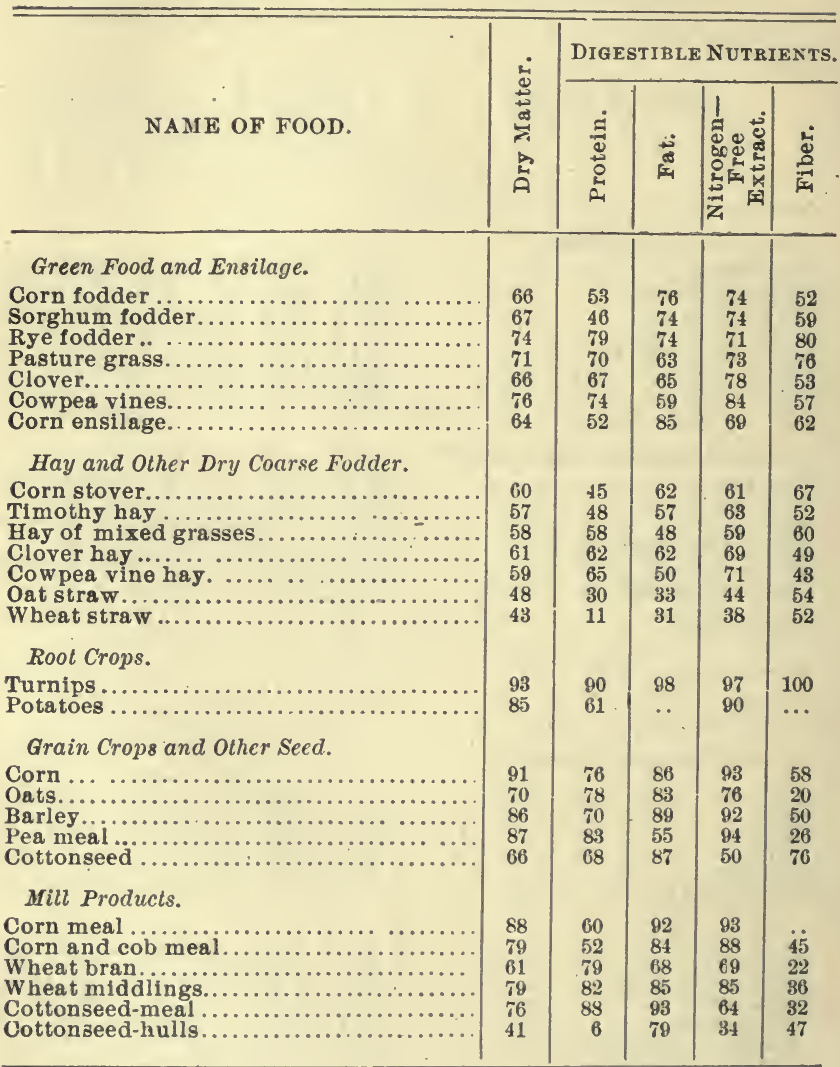




\section{Stock Foods-Continued}

\section{TABLE VII}

Average of Digestible Nutrients and Fertilizing Constituents in Slock Foods

\begin{tabular}{|c|c|c|c|c|c|c|c|}
\hline \multirow[b]{2}{*}{ NAME OF FOOD. } & \multirow{2}{*}{ 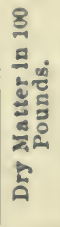 } & \multicolumn{3}{|c|}{$\begin{array}{l}\text { DIGRBTIBLE } \\
\text { NUTRIENTS IN } 100 \\
\text { POUND8. }\end{array}$} & \multicolumn{3}{|c|}{$\begin{array}{l}\text { FERTILIzING } \\
\text { Congtituksta IN } \\
\text { 100 POUNDS. }\end{array}$} \\
\hline & & 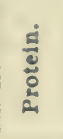 & $\underset{\sim}{\ddot{\alpha}}$ & 客 & 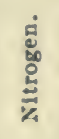 & 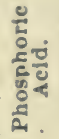 & $\begin{array}{l}\text { की } \\
\text { क् } \\
\text { \& }\end{array}$ \\
\hline \multicolumn{8}{|l|}{ Green Food and Ensilage. } \\
\hline Corn lodder & 20.7 & 1.n & 0.4 & 11.6 & 0.80 & 0,15 & 0.80 \\
\hline Sorkhi & 80.6 & 0.7 & 1.2 & 17.6 & 0.80 & 0.49 & 0.25 \\
\hline Rye & 23.4 & 2.1 & 0.4 & 14.1 & 0.63 & 0.25 & 0.70 \\
\hline Kentucky bluegrass. & 34.9 & 8.0 & 0.8 & 10.8 & & & \\
\hline Red clor & 29.2 & 2.8 & 0.7 & 11.8 & 0.54 & 0.15 & 0.40 \\
\hline Cowpea & 16.4 & .1 .8 & 0.2 & 8.7 & 0.27 & 0.10 & 0.80 \\
\hline Corn ensllage... & 20.0 & 0.9 & 0.7 & 11.8 & 0.28 & 0.10 & 0.87 \\
\hline \multicolumn{8}{|l|}{$\begin{array}{l}\text { Hay and Other Dry Coarse } \\
\text { Fodders. }\end{array}$} \\
\hline Corn stover... & 59.5 & 1.7 & 0.7 & 82.4 & 1.10 & 0.29 & 1.40 \\
\hline Mu & 86.8 & 2.8 & 1.4 & 43.4 & 1.00 & 0.50 & 1. 11 \\
\hline ixed grass & 87.1 & 5.8 & 1.2 & 40.9 & 1.40 & 0.27 & 1.55 \\
\hline Red & 84.7 & 7.6 & 2.0 & 88.4 & 2.00 & 0.88 & 2.20 \\
\hline vine bay. & 89.8 & 10.8 & 1.1 & 89.0 & 2.66 & 0.32 & 1. 17 \\
\hline Oat & 90.8 & 1.2 & 0.8 & 886 & 0.46 & 0.28 & 1. 77 \\
\hline Wheat straw. & 90.4 & 0.4 & 0.1 & 86.8 & 0.60 & 0.22 & 0.63 \\
\hline \multicolumn{8}{|l|}{ Root Crops. } \\
\hline Turnips & 0.6 & 1.0 & 0.2 & 6.1 & 0.19 & 0.09 & 0.34 \\
\hline Pore & 31.6 & 1.2 & ... & 24.1 & 0.24 & 0.08 & 0.87 \\
\hline \multicolumn{8}{|l|}{ Grain and Otner Sced. } \\
\hline Corr & 89.1 & 8.0 & 4.6 & 65.9 & 1.58 & 057 & 0.87 \\
\hline & 89.0 & 0.2 & 4.2 & 47.8 & 1.65 & 0.69 & 0.48 \\
\hline Bar & 89.1 & 8.7 & 1.6 & 65.6 & 1.51 & 0.79 & 0.48 \\
\hline Cor & 87.8 & 80.0 & 0.8 & 63.2 & 8.87 & 0.82 & 0.00 \\
\hline Costouseed & 60.1 & 18.2 & 16.9 & 20.1 & 8.10 & 1.06 & 1.00 \\
\hline Mill Products. & & & & & & & \\
\hline Corn meal. & 85.0 & 5.5 & 8.5 & 63.8 & 1.68 & 0.63 & 0.40 \\
\hline $\cos$ & 81.9 & 4 & 2.9 & 60.0 & $1+1$ & 0.57 & \\
\hline Wheat b & 88.1 & 12.2 & 27 & 89,2 & 2.67 & 280 & 1.3i \\
\hline Wheat a & 87.9 & 12.8 & 8.4 & 630 & 2.63 & 0.93 & 06 \\
\hline Cots & 91.5 & 88.1 & 12.6 & 16.0 & 6.90 & 3.00 & 1.60 \\
\hline Cotlonseed.hulls..... & 80.5 & 0.8 & 1.7 & 82.9 & 0.69 & 0.25 & 1.02 \\
\hline
\end{tabular}




\section{Stock Foods-Continued}

\section{TABLE VIII}

\section{Pu unds of Food Required Per Day for 1,000 Pounds Live Weight}

\begin{tabular}{|c|c|c|c|c|c|}
\hline \multirow{2}{*}{ KIND OF ANIMAL. } & \multirow{2}{*}{ 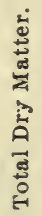 } & \multicolumn{3}{|c|}{$\begin{array}{l}\text { DIGESTIBLE } \\
\text { NUTRIENTS. }\end{array}$} & \multirow{2}{*}{ 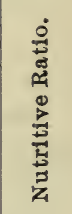 } \\
\hline & & 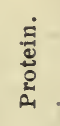 & •. & 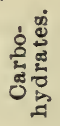 & \\
\hline Oren at rest in stall...... & 18 & 0.7 & $0: 1$ & 8.0 & $1: 11.8$ \\
\hline Oxen at moderate work...... & 25 & 2.0 & 0.5 & 11.5 & $1: 6.5$ \\
\hline Fattening cattle............. & 28 & 2 & 0.6 & 15.0 & 1: 6.1 \\
\hline Milch cows.. & 28 & 2. & 0.5 & 12.0 & 1: 5.3 \\
\hline Sheep, wool growing. ........ & 20 & 1. & 0.3 & 11.0 & 1: 7.8 \\
\hline Sheep, fattening............ & 29 & 3. & 0.6 & 15.0 & 1: E.5 \\
\hline Horses, moderate work....... & $2 \cdot 2$ & 1. & 0.6 & 11.0 & 1: 6.8 \\
\hline 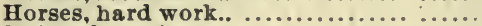 & 26 & 2.5 & 0.8 & 13.3 & 1: 6.0 \\
\hline Swine, fattening $\ldots \ldots \ldots \ldots \ldots \ldots \ldots$ & 32 & 4.0 & 0.5 & 24.0 & 1: 6.8 \\
\hline Growing Cattle. & & & & & \\
\hline $\begin{array}{ll}\text { Age in } & \text { Average live } \\
\text { months. } & \text { wt. perhead. }\end{array}$ & & & & & \\
\hline $2-3 \ldots \ldots \ldots \ldots$ & 22 & 4.0 & 2:0 & 13.8 & 1: 4.7 \\
\hline 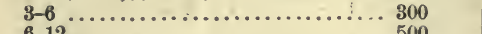 & 23 & 3.0 & 1.0 & 13.5 & $1: 5.3$ \\
\hline 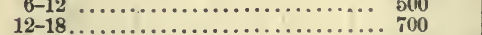 & $\begin{array}{l}24 \\
24\end{array}$ & 2. & $\begin{array}{l}0.6 \\
0.4\end{array}$ & $\begin{array}{l}13.5 \\
13.0\end{array}$ & $\begin{array}{l}\text { 1: } 6.0 \\
1: 7.0\end{array}$ \\
\hline 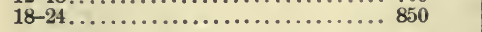 & 24 & 1.5 & 0.3 & 12.0 & $1: 8.5$ \\
\hline
\end{tabular}


Stock Foods-Continued

\section{TABLE IX}

Legal Weights of Grain, Seed, Elc.-Pounds Per Bushel Required by Law or Custom

\begin{tabular}{|c|c|c|c|c|c|c|c|c|c|c|c|c|c|}
\hline STATES. & $\frac{b}{2}$ & 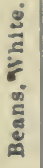 & 造 & 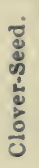 & 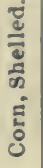 & $\begin{array}{l}\text { हैं } \\
\text { है } \\
\text { ह }\end{array}$ & हี & $\underset{0}{0}$ & 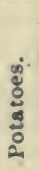 & 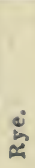 & $\frac{d}{8}$ & 良 & 感 \\
\hline New York & 48 & 62 & 48 & 60 & $k 8$ & & & 82 & 60 & 56 & BO & .. & 44 \\
\hline New Jers & 48 & & 50 & 64 & B6 & & 37 & so & BO & 66 & 60 & 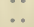 & 45 \\
\hline Peunsylvania & 17 & & 18 & 62 & 56 & is & 60 & 80 & 30 & 56 & 60 & .. & .. \\
\hline Delaware & . & & .. & - & 56 & 48 & .. & & & & 60 & .. & 0 \\
\hline Maryland .... & 17 & 62 & 10 & S0 & & & & 28 & 56 & 56 & & & \\
\hline Dis. of Columbia & 47 & 62 & 48 & $6 n$ & 56 & 48 & 57 & 82 & 56 & 56 & 60 & 55 & 45 \\
\hline Virginla........... & 48 & 60 & 52 & 64 & 56 & 80 & 57 & 82 & 60 & 56 & 60 & 56 & 45 \\
\hline $\begin{array}{l}\text { West Virginia... } \\
\text { North Carolima.. }\end{array}$ & $\begin{array}{l}48 \\
48\end{array}$ & 60 & 52 & 60 & 54 & 46 & .. & $\begin{array}{l}32 \\
80\end{array}$ & 60 & $\begin{array}{l}56 \\
56\end{array}$ & 60 & .. & 45 \\
\hline $\begin{array}{l}\text { North Caroliua } \\
\text { South Carolina }\end{array}$ & 4 & $\ddot{60}$ & 56 & 60 & 66 & 50 & $\ddot{57}$ & $\begin{array}{l}80 \\
82\end{array}$ & 60. & $\begin{array}{l}56 \\
56\end{array}$ & $\begin{array}{l}60 \\
60\end{array}$ & *. & $\ddot{0}$ \\
\hline $\begin{array}{l}\text { South Car } \\
\text { Georgla ... }\end{array}$ & $\begin{array}{l}90 \\
47\end{array}$ & & 62 & 60 & 56 & 48 & 67 & 82 & 60 & 56 & 60 & $\ddot{5} \dot{5}$ & $\ddot{45}$ \\
\hline Florida.... & 48 & 60 & 48 & 60 & 56 & 48 & 57 & 82 & 60 & 56 & 60 & 65 & 45 \\
\hline Alabama. & 47 & 60 & 48 & 60 & 56 & 48 & B7 & 82 & 60 & 56 & 60 & 65 & 45 \\
\hline Mlssisstppl.. & 48 & 60 & .. & 60 & 56 & 48 & .. & 82 & 60 & 56 & 60 & .. & 45 \\
\hline l.oulsiana... & & & & & 56 & 50 & & 82 & & & & & \\
\hline rexas.... & 48 & 60 & 12 & 60 & 56 & & 67 & 82 & 60 & 56 & 60 & 56 & 45 \\
\hline A rkansas..... & 48 & (6) & 52 & 60 & 66 & 48 & 57 & 82 & 60 & 56 & 60 & 57 & 60 \\
\hline Tennessee ... & 48 & 30 & 50 & 60 & 56 & 50 & 56 & 82 & 60 & 56 & 60 & 50 & 45 \\
\hline Kentucky... & 47 & 60 & 56 & 60 & 56 & 60 & 57 & 82 & 60 & 56 & 60 & 60 & 45 \\
\hline
\end{tabular}

Norz.-Tables I to VIII, are complled from data published in the lear books of the U. S. Dept. Agr., and from other sources. 



\section{N D E X}

Page.

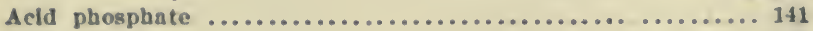

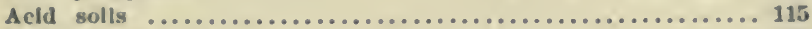

Aeration of golls ................................. 124

Agrleulture, Primary object of...................... 151

Alr, Composition of ................................ 24

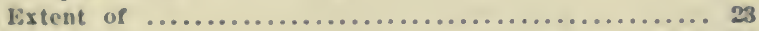

In the soll ................................ 126

Necessary for germination ....................... 35

Necessary for growing roots .................... 61

Sollds in .......................................

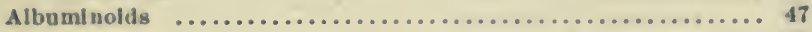

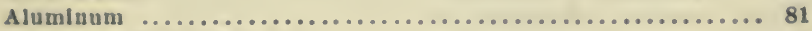

Ammonla, Definltion of ........................... 20

In the alt ............................ 61

Loss of, from manure................... 131

Sulphate of ..................................

Anlmals, Care of ...................................194

Composition of .........................181-1S5

Foud of .......................15t-189, 214-217

Growth of .............................. 186i

How to feed ........................18s, 196-197

Pasturing ..........................196, 197

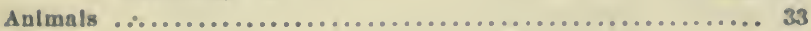

Apatste ......................................... 138

Apparatus for germinating seed................... 37

Asb. Eatimation of ............................. 200

Ashes, of animal bodles ............................. 1st

Of plnnts ...................................

Of woot .................................. 129

Atmosphere. See Alr.

Bacteria, In alr ................................

In mnnure ..........................130, 131

In solls ......................... 79, 95-98

Boneyard manure ............................. 120

Bean plant .......................................

Blendals ........................................ 33 


\section{.}

Page.

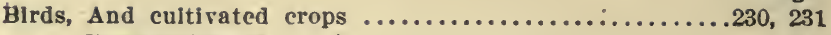

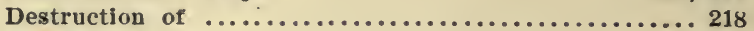

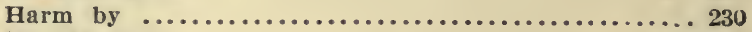

1isectlvorous .............................222-2227

Seed-eating .............................228-231

Value of $\ldots \ldots \ldots \ldots \ldots \ldots \ldots \ldots \ldots \ldots \ldots \ldots \ldots \ldots \ldots .219-221$

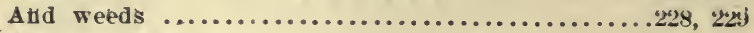

Birds of Pirey; Harm by .............................. 233

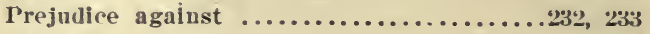

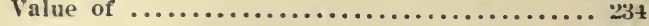

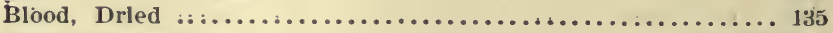

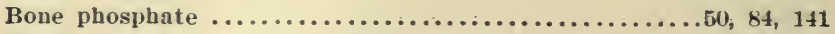

Bones ........................................... 181

Breatbing ....................................6

Calcium, Properties of $\ldots \ldots \ldots \ldots \ldots \ldots \ldots \ldots \ldots \ldots \ldots \ldots \ldots . \ldots \ldots 2$

In solls $\ldots \ldots$............................ 84

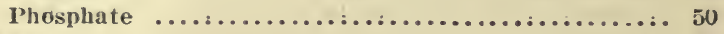

Chrbohydrates ..................................... 48

Carbon; Properties of ............................. 26

Sources of, in platits........................

Carbon Dioxlde, Formation of ....................... 26

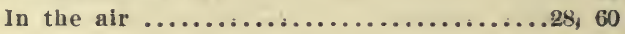

Cellulose .......................................... 48

Cereals .......................................... 157

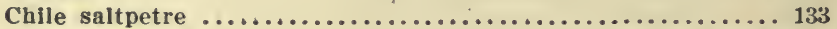

Chlorophyll ................................43, 58, 65

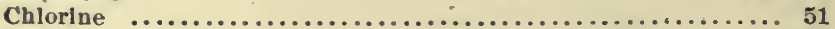

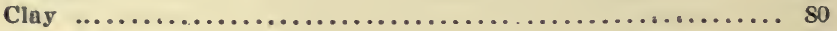

Clouds .......................................... 12

Clorers ................................96, 157, 166-168

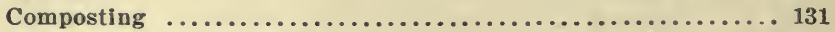

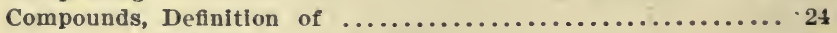

Manufactured in plant.....................64 64

Cendensation .................................... 11

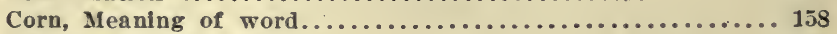

Germination of seed $\ldots \ldots \ldots \ldots \ldots \ldots \ldots \ldots \ldots \ldots \ldots \ldots, 36$

Roots of plant $\ldots \ldots \ldots \ldots \ldots \ldots \ldots \ldots \ldots \ldots \ldots \ldots \ldots \ldots, 40$

As a crop..................................... 159

Cotton, As a crop.................................. 174

Cottonseed-meal ................................... 134

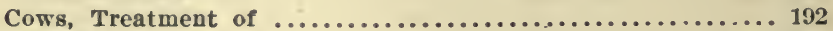

Cowpeas ....................................146, 167

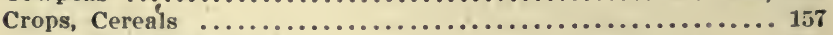

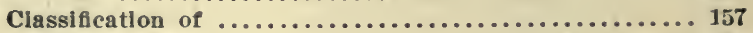

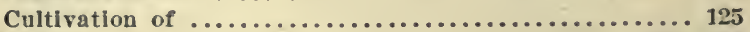

Fodder ................................... 164

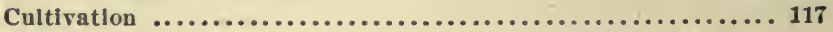


Page.

Dentrifleation ................................. 108

Deserts ........................................ 101

Dew $\ldots \ldots \ldots \ldots \ldots \ldots \ldots \ldots \ldots \ldots \ldots \ldots \ldots \ldots \ldots \ldots \ldots \ldots \ldots \ldots \ldots \ldots \ldots \ldots \ldots \ldots$

Digestion, Coefflelents of .......................... 200

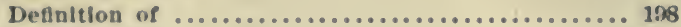

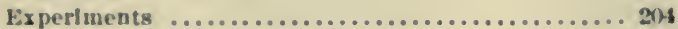

Dralns .......................................... 119

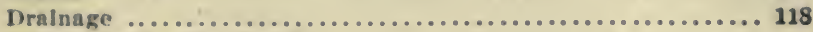

Dried Blood. See Bloor.

Dry Fodder. See Foduler.

Dry Matter, of animals ............................ 182

Of plants ........................... 46

Dust ......................................... 30

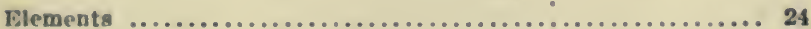

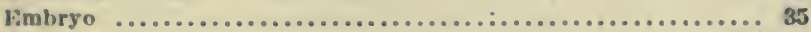

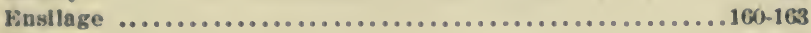

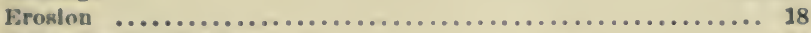

Evaporation, Defintion of ............................ 11

As a temperature regulator................ 21

Surface ............................... 103

Fall plowing .................................... 124

barmlng, General and spectal........................ 152

Fat, Crude, listlmatton of .......................... 200

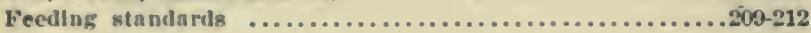

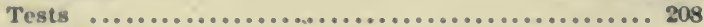

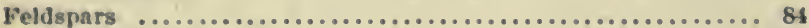

Fertllity of solls ................................... 100

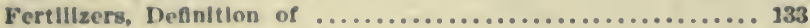

Manufacture of .......................... 140

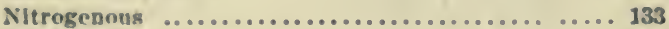

Phosphatic ............................ 137

I'otassle .................................. 136

Valuation of $. \ldots \ldots \ldots \ldots \ldots \ldots \ldots . . . . .142-144$

Fiber, Crude, Vistluation of........................ 201

Flim molsture .................................. 89

Flsh werap ......................................... 136

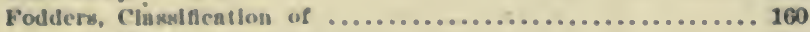

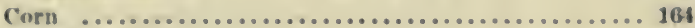

Definttlon of $\ldots \ldots \ldots \ldots \ldots \ldots \ldots \ldots \ldots \ldots \ldots \ldots \ldots \ldots$ 10.

1)ry, coarse .................................. 164

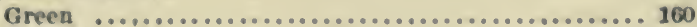

Palled ................................... 164

Fogs ............................................... 12

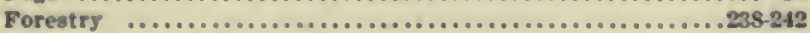

Forests, As a crop ................................. 240

Destruction ot ............................... 239

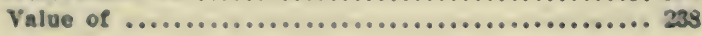




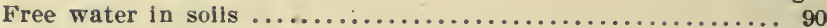

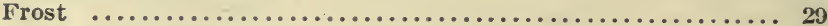

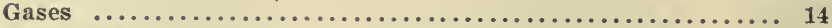

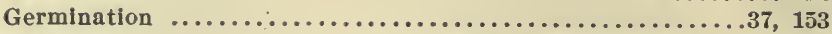

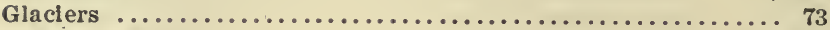

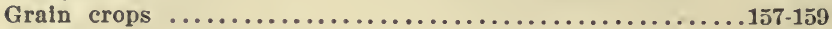

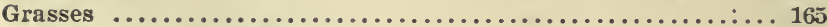

Green Fodder. See Fodder.

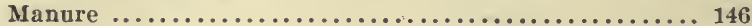

Ground water ........................................ 91

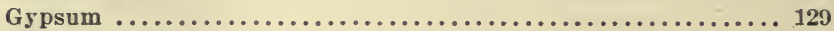

Hail $\ldots \ldots \ldots \ldots \ldots \ldots \ldots \ldots \ldots \ldots \ldots \ldots \ldots \ldots \ldots \ldots \ldots \ldots \ldots \ldots \ldots, 12$

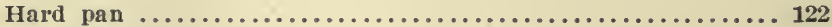

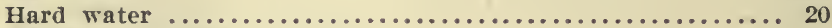

Hawks. See Bilds of Prey.

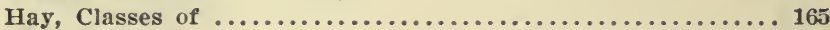

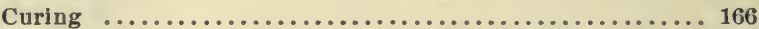

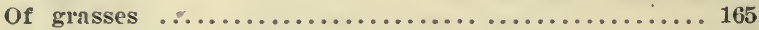

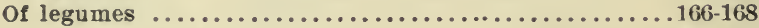

Time for cutting ............................. 168

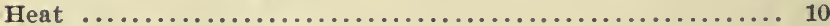

Herbivorous animals .................................. 196

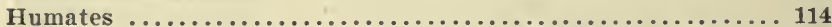

Humus .....................70, 79, 107, 111, 113, 114, 115

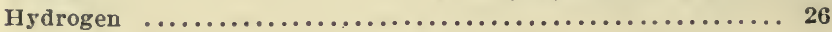

Indian Corn. See Corn.

Inorganic matter of soils..................... 70,79

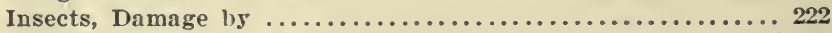

Eaten by birds ................................ 2225

Irish potato ........................................ 173

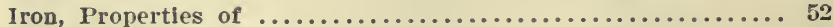

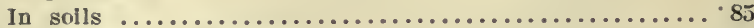

Iron and aluminum phosphate..................... 84

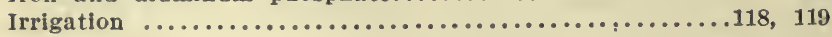

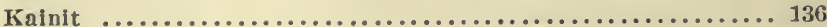

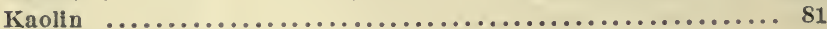

Land ......................................... 67

Land plaster .................................... 1:9

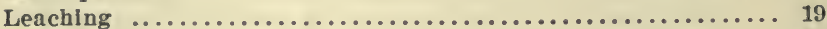

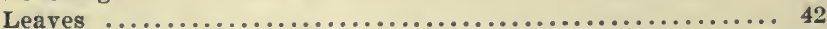

Leguminosæ Piants, Fixation of nltrogen by.......... 96

For hay ........................ 166

For manure $\ldots \ldots \ldots \ldots \ldots \ldots \ldots \ldots \ldots \ldots . . \ldots \ldots$

Lfe in the soll $\ldots \ldots \ldots \ldots \ldots \ldots \ldots \ldots \ldots \ldots \ldots \ldots \ldots \ldots \ldots \ldots \ldots . . . \ldots 115$ 
Page.

I.Ight, Effect on plant......................... 16

Lame, Formation of ............................ 52 In solls ............................ 86, 114, 115

I.Imestone solls ............................... 85

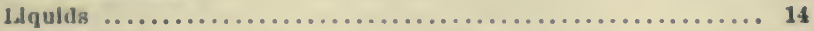

Loamy solls .................................. 74

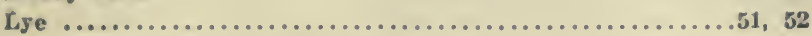

Magneslum ................................. 52

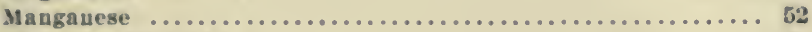

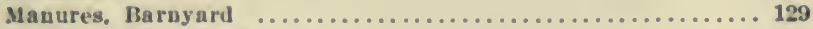

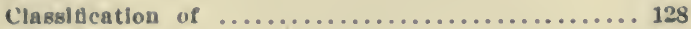

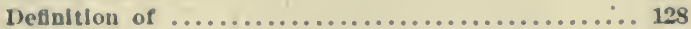

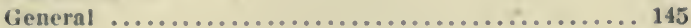

Greeu ................................ 146

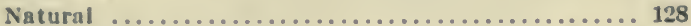

Purpose of ................................ 145

Speclal ........................... 145, 148, 149

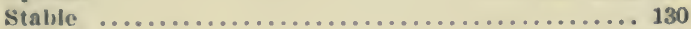

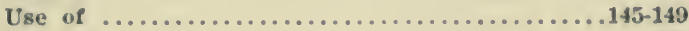

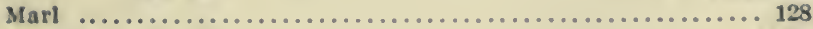

Meteors ............................................ 19

Meteorology .................................. 31

Mlineral matter of plants ......................... 46

Compositton of ........................... 50

Sources of ............................... 63

Mlueral matter of solls ......................, 71, 79

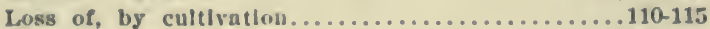

MIsslsslppl IRlver .............................22, 239

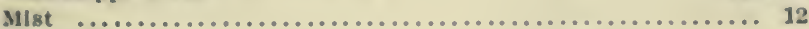

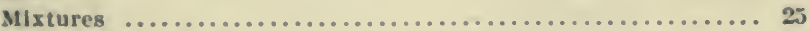

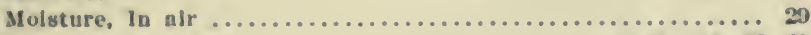

In plants ...................5, 5i, 56, 57, 63

In solls ............ T8, 83, 88-93, 100-105, 118-120, 124

Effect on temperatures ..................29, 30

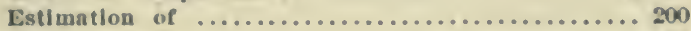

Mold ................................................ 31

Mluck ................................................

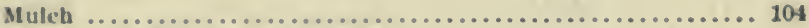

Murlate of l'otash. See Potash.

Nile River ..................................... 120

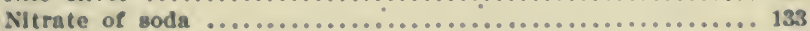

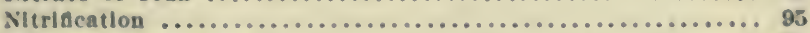

Nitrogen, Free extract ............................. 201

Propertles of ............................. $\mathbf{2 6}$

In the alt ........................... 28

In plants .....................46, 47, 57, 62 
Nitrogen in Soils, Importance of $\ldots \ldots \ldots \ldots \ldots \ldots \ldots \ldots . . \ldots 4$

Page.

Sources of $\ldots \ldots \ldots \ldots \ldots \ldots \ldots \ldots . . .24,98,106$

Forms of $\ldots \ldots \ldots \ldots \ldots \ldots \ldots \ldots \ldots \ldots \ldots \ldots \ldots$

Necessity of $\ldots \ldots \ldots \ldots \ldots \ldots \ldots \ldots \ldots, 106$

Loss of $\ldots \ldots \ldots \ldots \ldots \ldots \ldots \ldots \ldots \ldots, 108$

Nitrogenous Matter. See Protein:

Non-Nitrogenous Matter, In Plants ................... 48

In animals $\ldots \ldots \ldots \ldots \ldots \ldots \ldots \ldots \ldots \ldots$. 184

EstImation of $\ldots \ldots \ldots \ldots \ldots \ldots \ldots .201$

Nutrlents .................................. 202

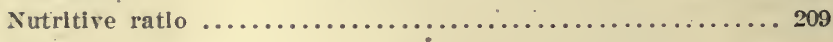

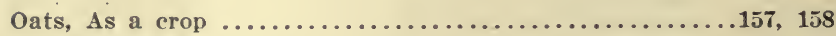

Roots of ................................ 41

Organlc matter of plants ....................... 46

Of solls.........70,78, $79,86,94,95,98,106,107$

Organs of plants $\ldots \ldots \ldots \ldots \ldots \ldots \ldots \ldots \ldots \ldots \ldots \ldots \ldots, 38$

Orls. See Birds of Prex.

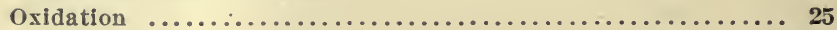

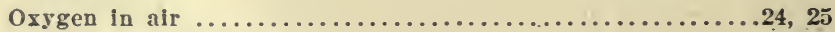

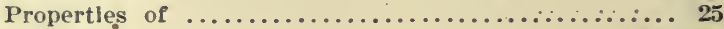

In solls .............................. 124

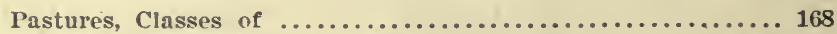

Permanent .............................., 169

Temporary ...........................169, 170

Peaty soils $\ldots \ldots \ldots \ldots \ldots \ldots \ldots \ldots \ldots \ldots \ldots \ldots \ldots \ldots \ldots \ldots \ldots \ldots \ldots \ldots, 74$

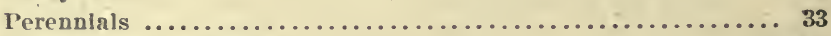

Phosphates, In plants ............................ 58

In soils $\ldots \ldots \ldots \ldots \ldots \ldots \ldots \ldots \ldots \ldots . \ldots \ldots, 110-113$

In fertilizers $\ldots \ldots \ldots \ldots \ldots \ldots \ldots \ldots \ldots \ldots$. $133,138-143$

Phosphate Rock, Where found ....................... 138

Appearance of ..................... 139

Composition of ..................... 139

Phosphoric acid ............................... 51

Phosphorus, Properties of ........................ 50

In soils ..........................., 110

In fertillzers ............................. 133

In phosphate rock ........................ 139

Plants, Classes of .................................. 33

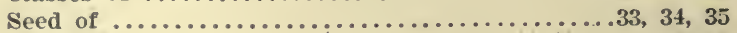

Parts of ......................................... 48

Composition of ..............................45-53

Food of ......................................

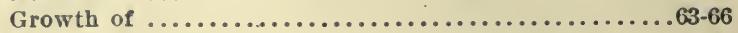

Plant food ......................................... 58

Plowing ........................................ 125 
Potasslum, Propertles of .......................... 51

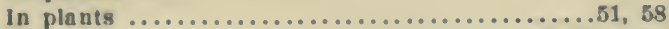

In solls .......................... 84, 113, 114

In fertllizers ......................133, 136, 137

Preteln, In plants .........................46, 47, 65

Properties of ............................47

In animals ..........................183, 199, 200

In fools .................................200

Quartz ............................................ so

Qulck llime ...................................... 52

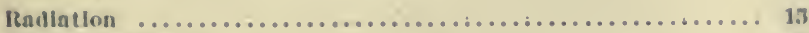

Radlsh plants .................................... 41

Raln, Formatioin of ................................ 12

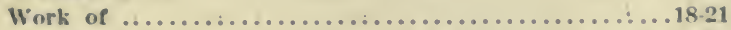

A robluer ................................. 20

itatlo, Nutration. See Nutritive.

Bntlous for Anlmals ...............................206-213

Componnding ............................209.212

Weighing ..............................204, 20.3

filce as a crop ..................................... 157

Roads, Interest In ................................... 243

Formatlon of ..............................243

Of dirt ...........................................

Loeation of .................................. 44

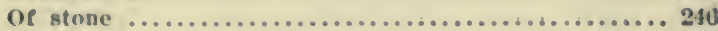

Macalnm ................................248

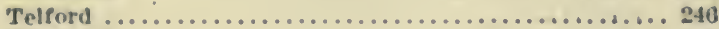

Value of ...............................247

Cost of haullug over ......................... 24!)

Rocks ............................................ 67

Root crops ...................................... 17'

Root halrs .....................................40,41

Iroots ...........................................39-42

Rotation of erops .................................. 177

Benents of ............................179

Example of ............................ 180

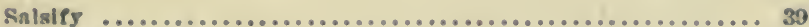

Salt, In the soll ................................... 19

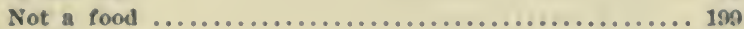

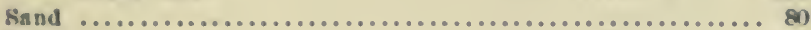

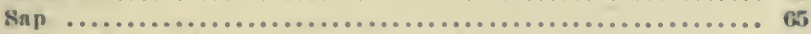

Selliment ......................................... 18

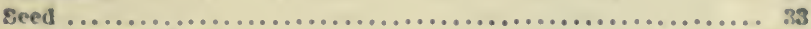

Sprouting of ...................................34

Texting ......................................151-15n

Selection of ................................ 1:2

Purity of ..................................... 152 


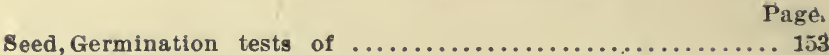

Necessity for testing .............................. 153

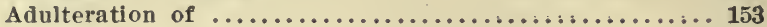

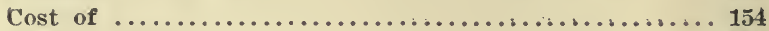

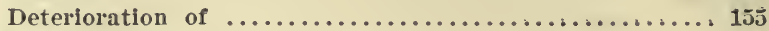

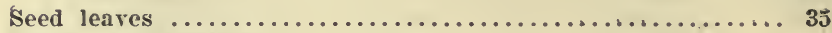

Silage. See Ensilage.

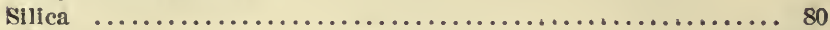

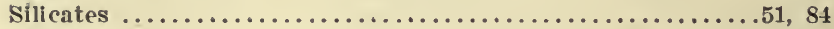

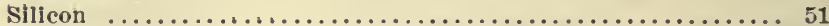

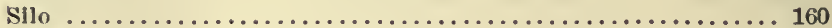

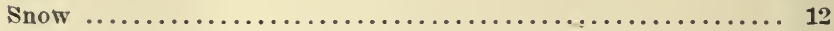

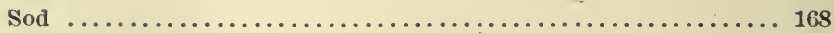

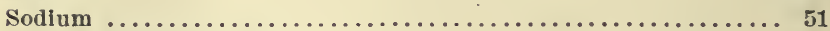

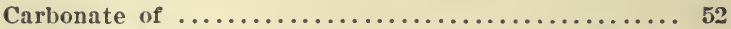

Soft Water. See Water.

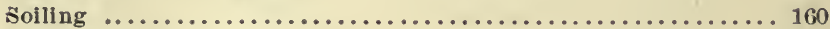

Solls; Definition of $\ldots \ldots \ldots \ldots \ldots \ldots \ldots \ldots \ldots \ldots \ldots \ldots \ldots \ldots \ldots$

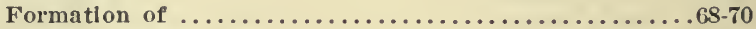

Organic matter in..................70, 78, 79

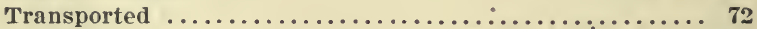

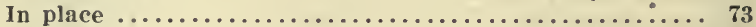

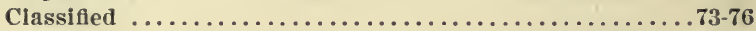

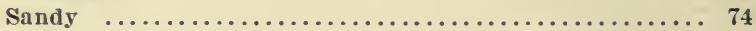

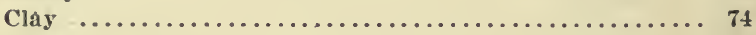

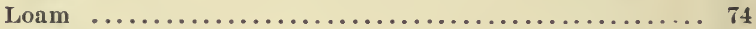

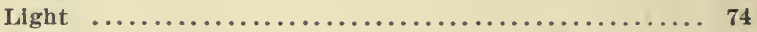

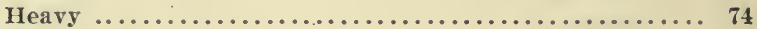

Weight of $\ldots \ldots \ldots \ldots \ldots \ldots \ldots \ldots \ldots \ldots \ldots \ldots \ldots \ldots \ldots \ldots$ i5

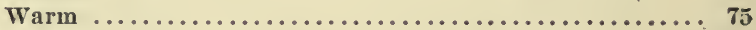

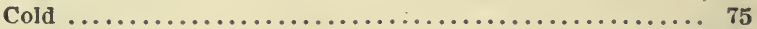

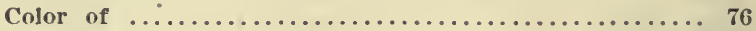

Water in $\ldots \ldots \ldots \ldots \ldots \ldots \ldots \ldots \ldots \ldots \ldots \ldots \ldots \ldots . . \ldots \ldots, 88.93$

Inorganic matter in $\ldots \ldots \ldots \ldots \ldots \ldots \ldots \ldots \ldots \ldots \ldots \ldots \ldots$

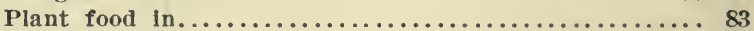

Phosphorus in ....................... 110-113

Potash in ............................ 113, 114

Calcium in $\ldots \ldots \ldots \ldots \ldots \ldots \ldots \ldots \ldots \ldots \ldots \ldots \ldots \ldots \ldots . \ldots 4$

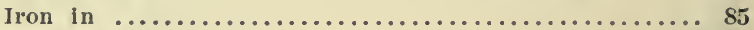

Analyses of $\ldots \ldots \ldots \ldots \ldots \ldots \ldots \ldots \ldots \ldots \ldots \ldots \ldots \ldots \ldots \ldots$

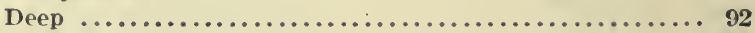

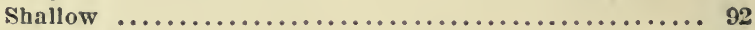

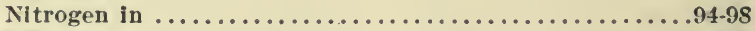

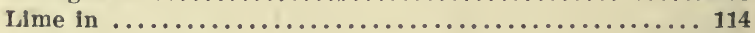

Loss of water in .................................

Loss of fertility ..........................100-116

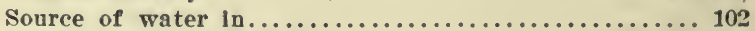

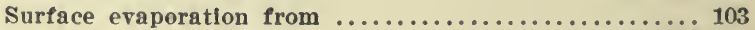

Loss of nitrogen in ...................... 106-108 
Page.

Solls, Loss of mineral matter in ....................110-116

Idfe In ................................... 115

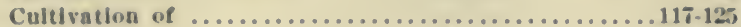

Alr In .................................... 124

Restoration of ................................ 148

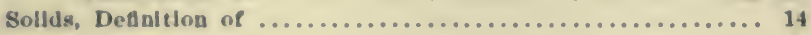

In the alr ................................ 30

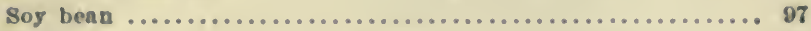

Spriags ..................................... 91

Stable Manure. See Manure.

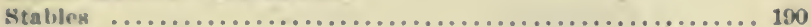

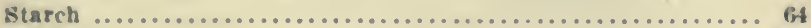

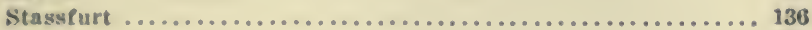

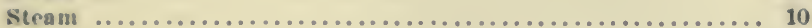

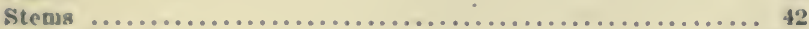

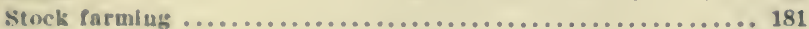

stock Fouds ................................... 198. 302

Composition of $\ldots \ldots \ldots \ldots \ldots \ldots \ldots \ldots \ldots \ldots \ldots . . .200-202$

Cost of $\ldots \ldots \ldots \ldots \ldots \ldots \ldots \ldots \ldots \ldots \ldots \ldots \ldots . .216,217$

Digestlbillty of .......................204-207

Selection of $\ldots \ldots \ldots \ldots \ldots \ldots \ldots \ldots \ldots \ldots \ldots \ldots . . .214-217$

Volume of ............................. 214

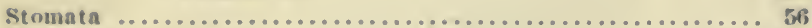

Stomacbs of antmals ..........................214. 215

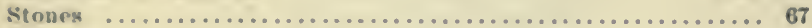

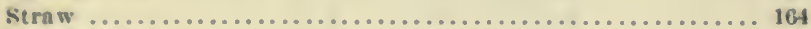

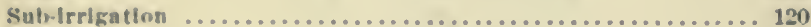

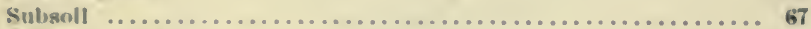

Sugar In plants ........................... 48

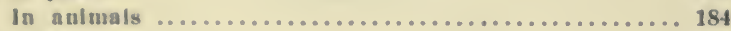

Sulphur ............................... 47

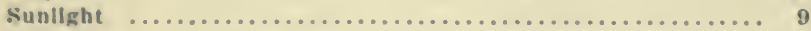

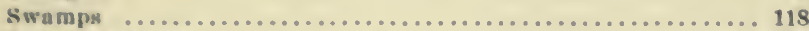

Sweet potatoes ...............................40, 173

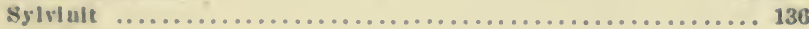

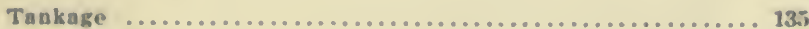

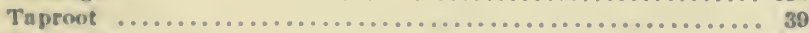

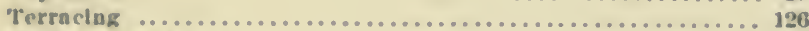

Thernometers ........................................ 14

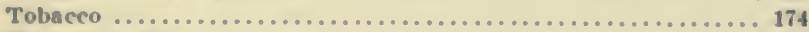

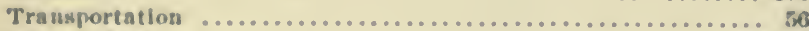

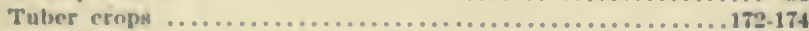

Tubercles ........................................ 97

Under dralns ................................ 119

Velus of leares ................................ 43

Velocity of heat and llght............................ 46

Ventlation of stables ............................... 100 
Volatilt matter of plants....................... 46

of animals $\ldots \ldots \ldots \ldots \ldots \ldots \ldots \ldots \ldots \ldots \ldots \ldots \ldots \ldots$

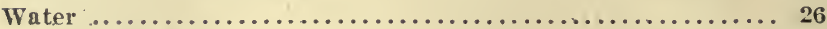

Vapor of $\ldots \ldots \ldots \ldots \ldots \ldots \ldots \ldots \ldots \ldots \ldots \ldots \ldots \ldots \ldots \ldots \ldots \ldots \ldots \ldots \ldots \ldots, 29$

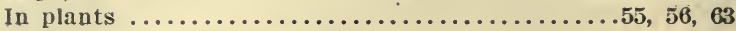

Mechanical action of, on solis................ 68

Chemical action of, on solls.................. 69

Transports solls ...................... 72

In solls $\ldots \ldots \ldots \ldots \ldots \ldots \ldots \ldots \ldots \ldots \ldots 75,78,88,93,118,120$

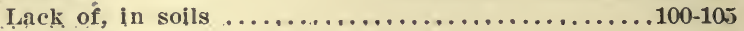

In animal bodles $\ldots \ldots \ldots \ldots \ldots \ldots \ldots \ldots \ldots \ldots \ldots \ldots \ldots \ldots$

For stock ................................. 195

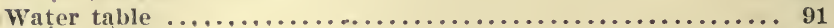

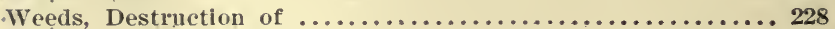

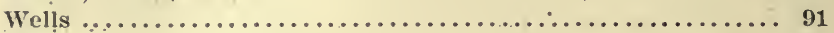

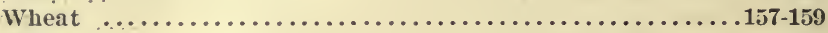

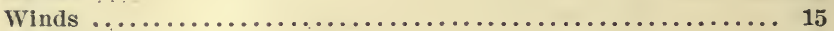

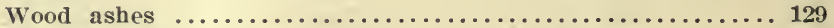

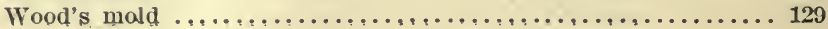

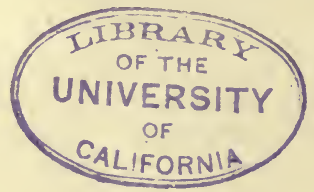








\section{YB 45439}

\section{$\frac{\text { Ens }}{\text { nos nel }}$}

McBryde 


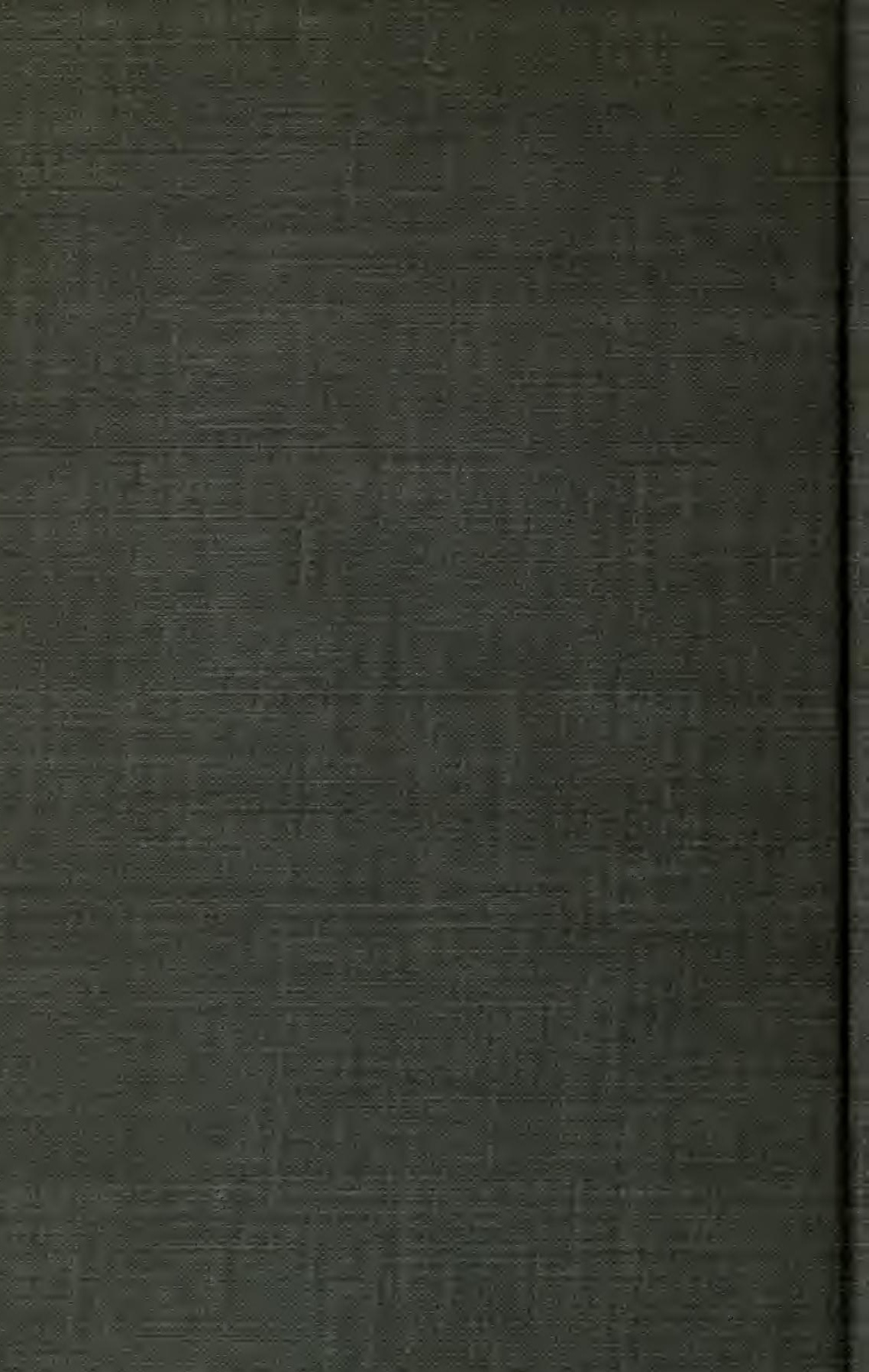

